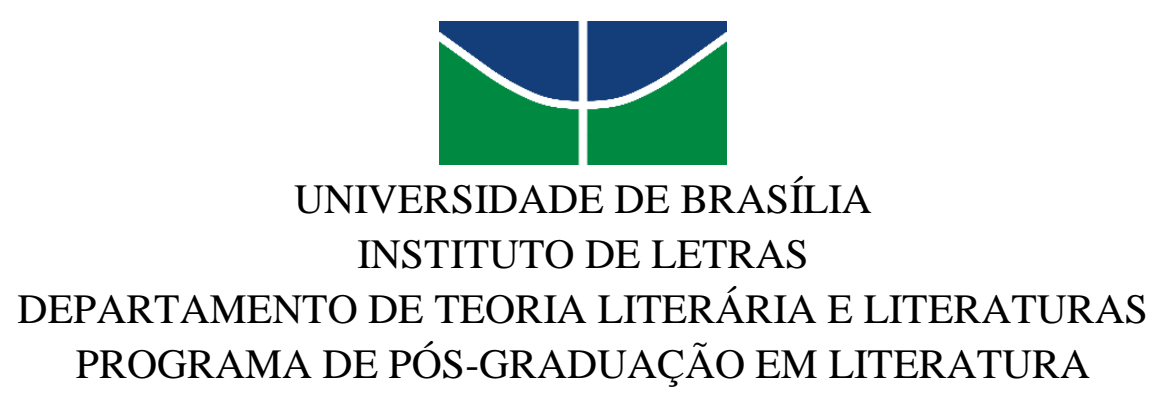

DÉBORA RESENDE BEZERRA

A FIGURA DE DUCHAMP EM VILA-MATAS: DE SHANDYS, DYLANS E OUTRAS MÁSCARAS

BRASÍLIA

2017 


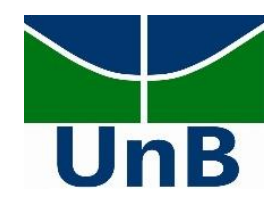

DÉBORA RESENDE BEZERRA

A FIGURA DE DUCHAMP EM VILA-MATAS: DE SHANDYS, DYLANS E OUTRAS MÁSCARAS

Dissertação apresentada ao programa de Pós-Graduação em Literatura do Departamento de Teoria Literária e Literaturas - TEL do Instituto de Letras da Universidade de Brasília como requisito parcial para a obtenção do título de Mestre.

Área de concentração: Literatura

Linha de Pesquisa: Literatura e Outras Artes

Orientador: Prof. Dr. Erivelto da Rocha Carvalho

BRASÍLIA

2017 


\section{A FIGURA DE DUCHAMP EM VILA-MATAS: DE SHANDYS, DYLANS E OUTRAS MÁSCARAS}

Banca Examinadora:

Prof. Dr. Erivelto da Rocha Carvalho (TEL/UnB)

(Presidente da Banca)

Prof. Dr. Kelvin dos Santos Falcão Klein (UniRio)

(Membro Externo)

Prof. Dr. José Luis Martínez Amaro (TEL/UnB)

(Membro Interno)

Prof. Dr. Augusto da Silva Rodrigues Júnior (TEL/UnB)

(Membro Suplente) 


\section{AGRADECIMENTOS}

Ao meu orientador, prof. Dr. Erivelto Carvalho, porque mais importante que ter ideias é compartilhá-las e eu tive a sorte de compartilhar muitas com ele. Obrigada por me oferecer a passagem para embarcar nessa desafiadora viagem.

Aos professores Dr. Augusto Rodrigues da Silva Júnior e Dr. Marcos Fabrício Lopes da Silva, membros da banca de Qualificação, pelas sugestões, conselhos e contribuições para o desenvolvimento da pesquisa.

À minha mãe, Solange, meu amor maior. Obrigada por ser meu porto seguro, minha melhor amiga e maior exemplo.

Ao meu pai, Manoel. Obrigada pelo amor, carinho e apoio de sempre.

Ao meu irmão, Lucas, pelos momentos de descontração e pelas conversas noturnas inspiradoras.

À toda minha família, meu maior motivo de gratidão na vida.

À Jéssica da Silva, amiga-irmã que tive a sorte de conhecer ainda na infância e é personagem central na história da minha vida. Obrigada pela amizade de sempre e pela revisão deste trabalho.

À Sheila Valéria pelas discussões sobre Vila-Matas e por ser um dos presentes que a vida me deu ao ingressar na UnB.

À Aline dos Santos e Mariana Batista, grandes amigas com quem tenho o prazer de compartilhar e rir das alegrias e dos percalços da vida.

Ao Eduardo Manfredini, por ser uma das primeiras pessoas a me ensinar que leitura e escritura podem ser a mais poderosa forma de libertação.

Aos colegas de graduação e pós-graduação com quem pude compartilhar tantos momentos e conhecimento.

À Coordenação de Aperfeiçoamento de Pessoal de Nível Superior (CAPES), pela concessão da bolsa durante parte do período de realização deste mestrado. 
Solo sé que me fascina escribir sobre el misterio de que exista el misterio de la existencia del mundo, porque adoro la aventura en todo texto que se pone en marcha.

Enrique Vila-Matas 


\section{RESUMO}

Desde a publicação de seus primeiros livros, o romancista espanhol Enrique Vila-Matas propõe uma literatura de rupturas. O autor, que é hoje um dos mais destacados nomes da literatura espanhola e mundial, teve de enfrentar severas críticas ao optar por seguir o caminho oposto ao da tradição. Ao longo dessa jornada, Vila-Matas evocou em seus textos uma grande quantidade de figuras de escritores e artistas que, assim como ele, sempre estiveram dispostos a romper qualquer limite imposto pelo cânone, sendo Marcel Duchamp uma das mais constantes e relevantes destas figuras. Este trabalho estuda os romances Historia abreviada de la literatura portátil (1985) e Aire de Dylan (2012) a partir da Estética da Recepção. Sob a luz desta teoria, discute-se a relação entre realidade e ficção nas obras do autor e analisa-se como a figura de Duchamp se constitui como uma "figura de relevância", articulando os diversos níveis textuais do "horizonte de expectativa" da narração. Através do diálogo que Vila-Matas estabelece com obras do artista francês e com as de diversos artistas, o autor propõe reflexões sobre sua própria obra e sobre a história da literatura, convocando o leitor a também desempenhar seu papel nesse jogo, no qual sua experiência e imaginação se tornam as peças que completam estes quebra-cabeças abertos ao público.

Palavras-chave: Recepção; Figura de Relevância; Marcel Duchamp; Ficção; Realidade. 


\begin{abstract}
Since the publication of his first books, the Spanish novelist Enrique Vila-Matas proposes a literature of ruptures. The author, who is now one of the most prominent names in Spanish and worldwide literature, has faced severe criticism in choosing to follow the opposite path to tradition. Throughout this journey, Vila-Matas evoked in his texts a great number of figures of writers and artists who, like him, have always been willing to break any limit imposed by the canon, being Marcel Duchamp one of the most constant and relevant figures. This paper studies the novels Historia abreviada de la literatura portátil (1985) and Aire de Dylan (2012) from the Reception Theory. Under the light of this theory, the relation between reality and fiction in the works of the author is discussed and it is analyzed how the figure of Duchamp constitutes as a "figure of relevance", articulating the diverse textual levels of the "horizon of expectation" of the narrative. Through the dialogue that establishes with works of the French artist and several authors, Vila-Matas proposes reflections on his own work and on the history of literature, inviting the reader to play his role in this game, in which his experience and imagination become the pieces that complete these jigsaw puzzles open to the public.
\end{abstract}

Keywords: Reception; Figure of Relevance; Marcel Duchamp; Fiction; Reality. 


\section{RESUMEN}

Desde la publicación de sus primeros libros, el escritor español Enrique Vila-Matas propuso una literatura de rupturas. El autor, que es actualmente uno de los principales nombres de la literatura española y mundial, tuvo que enfrentarse a severas críticas al optar por seguir el camino opuesto a la tradición. A lo largo de este camino, Vila-Matas ha evocado en sus textos una gran cantidad de figuras de escritores y artistas que, como él, siempre estuvieron dispuestos a romper cualquier límite impuesto por el canon, siendo Marcel Duchamp una de las más constantes e importante de estas figuras. Este trabajo estudia las novelas Historia abreviada de la literatura portátil (1985) y Aire de Dylan (2012) a partir de la Estética de la Recepción. A la luz de esta teoría, se analiza la relación entre la realidad y ficción en las obras del autor y la manera como la figura de Duchamp se constituye como una "figura de relevancia", articulando los diversos niveles textuales del "horizonte de expectativas" de la narración. A través del diálogo establecido con las obras del artista francés y otros varios autores, Vila-Matas propone reflexiones sobre su propia producción y sobre la historia de la literatura, invitando al lector a desempeñar su papel en este juego, en el que su experiencia e imaginación se convierten en piezas que completan estos rompecabezas abiertos al público.

Palabras clave: Recepción; Figura relevancia; Marcel Duchamp; Ficción; Realidad. 


\section{LISTA DE FIGURAS}

Figura 1: L.H.O.O.Q. (Duchamp, 1919)_..................................22

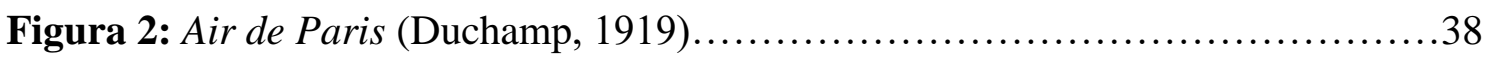

Figura 3: Bô̂te-en-valise (Duchamp, 1941)...................................60

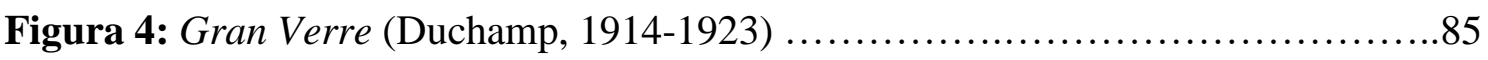

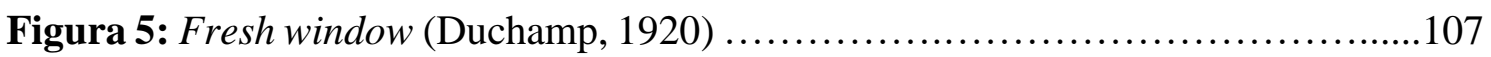




\section{SUMÁRIO}

INTRODUÇÃ̃O

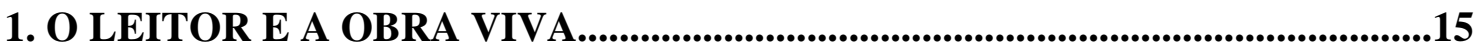

1.1 A obra de Enrique Vila-Matas pelo prisma da recepção........................................ 16

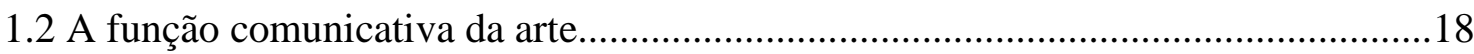

$1.3 \mathrm{O}$ problema da representação e do reflexo estético...................................................25

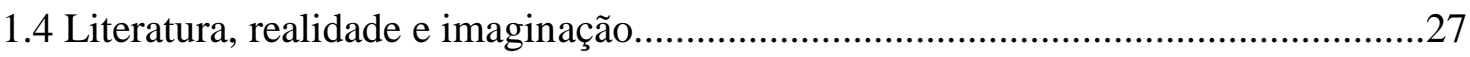

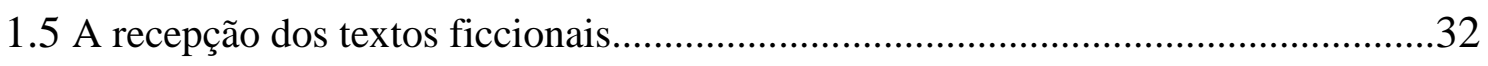

2. O IMPORTANTE É TER IDEIAS....................................................................35

2.1 Marcel Duchamp como "figura de relevância"........................................................36

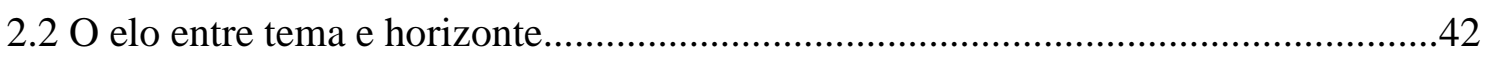

2.3 Um voo panorâmico pela obra de Enrique Vila-Matas............................................45

2.4 A dimensão duchampiana na obra de Vila-Matas....................................................55

3. A ARTE DA CONTRADIÇÃO_.......................................................................65

3.1 Breve história de uma sociedade infraleve...............................................................66

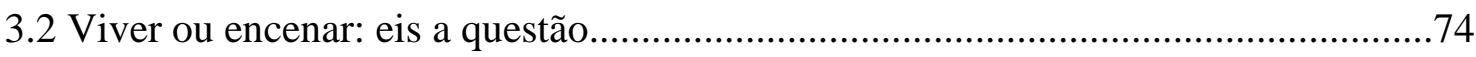

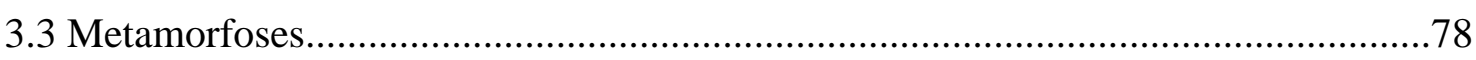

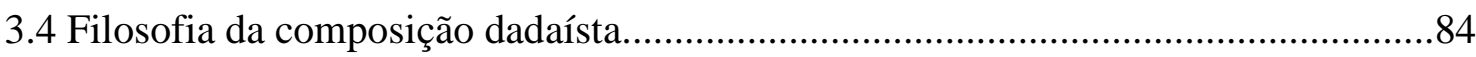

4. POR TERRENOS DESCONHECIDOS...............................................................87

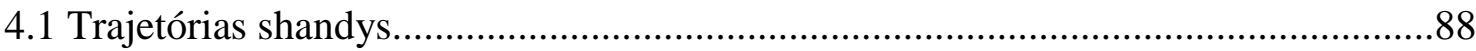

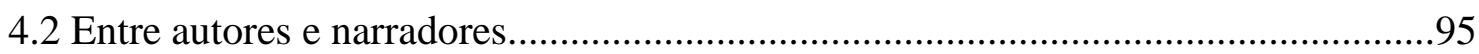

4.3 Vila-Matas, Duchamp e os sentidos por trás do sem sentido.................................97

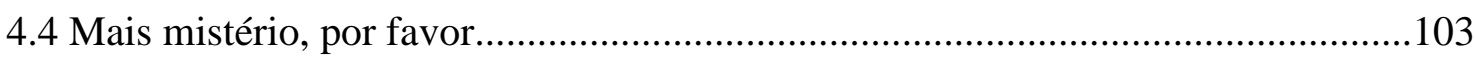

CONSIDERAÇÕES FINAIS............................................................................109

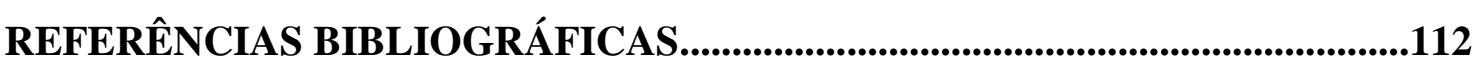




\section{INTRODUÇÃO}

Itinerário comentado

Esta pesquisa teve início em 2012, quando eu tive meu primeiro contato com a obra do autor espanhol Enrique Vila-Matas (1948). Eu estava então no $5^{\circ}$ semestre da graduação em Letras Espanhol, e cursava a disciplina Literatura espanhola 3 - século $X X$, ministrada pelo professor Erivelto da Rocha Carvalho, meu orientador neste e em outros projetos.

Foi nesta disciplina que, pela primeira vez, ouvi falar no autor catalão e tive acesso a um dos diversos livros que compõem sua extensa bibliografia. O livro era Historia abreviada de la literatura portátil, publicado em 1985 e responsável pela guinada da carreira literária de Vila-Matas que, com o lançamento do romance, passou a ser mais conhecido em seu próprio país, mas principalmente fora dele.

Ainda como leitora desavisada, caí nas diversas armadilhas que suas narrativas costumam apresentar. Tomei certos eventos como reais sem saber que estes se deram apenas na imaginação do autor. Acreditei que as diversas citações presentes no romance eram realmente palavras das pessoas as quais o narrador as atribuía, para somente depois me dar conta que a maior parte delas também se tratava de invenções.

Outras vezes, tentando não cair no mesmo erro, tratei de considerar que as palavras entre aspas, que se encaixavam perfeitamente às suas narrativas, pertenciam somente ao autor e a seus narradores, para depois ter a surpresa de encontrá-las em obras de outros autores.

Interrompi minha leitura em diversos momentos para fazer buscas no Google com o intuito de averiguar se episódios eram ou não reais. Tal ato certamente seria reprovado por Vila-Matas, visto que em vários momentos ele afirma que esta é uma pergunta frívola que não deveria importar tanto a um leitor de ficção; embora ele mesmo admita que - uma vez ou outra - não resistiu perguntar a seus amigos escritores se certos eventos que estes narraram haviam realmente acontecido.

Também busquei no Google informações sobre os abundantes nomes de obras, escritores e artistas mencionados pelo autor. Alguns deles eu já conhecia, outros conheci 
graças às alusões feitas por Vila-Matas, além, claro, daqueles que descobri serem apenas suas invenções.

Depois desse primeiro contato, um tanto desnorteado, mas com certeza bastante prazeroso, com Historia abreviada de la literatura portátil, li Bartleby y compañía (2000). Agora já estava mais atenta ao fato de que - apesar do narrador também ser um escritor barcelonês cheio de características em comum com Vila-Matas - os dois não eram a mesma pessoa.

Com a leitura de Bartleby y compañía, mais uma vez, conheci novos artistas e me reencontrei com outros que já estavam presentes em Historia abreviada. Alguns deles, especialmente o francês Marcel Duchamp (1887-1968), continuavam exercendo um papel essencial na construção da narrativa, fato que me chamava cada vez mais a atenção.

Após terminar de ler este livro, que é também um catálogo de artistas que por alguma razão decidiram abandonar a produção artística, eu também comecei a me lembrar de outros artistas não mencionados por Vila-Matas que tiveram destinos semelhantes a alguns daqueles "artistas do não". Anos mais tarde, o autor comenta que a princípio não lhe agradava a quantidade de mensagens de pessoas que, assim como eu, haviam começado a criar suas próprias listas de portadores da "síndrome de Bartleby". Porém afirma que logo se deu conta de que o fato de haver tantos leitores que queriam, de certa forma, completar o livro era um fato positivo e prova de que era justamente por também estar nas mãos dos leitores que o livro tinha vida.

Então, em 2013, dei início a um trabalho de iniciação científica, também orientado pelo professor Erivelto Carvalho, que investigava a dimensão que a figura de Marcel Duchamp ocupa em Historia abreviada e analisava este romance a partir do prisma da Estética da Recepção. Este trabalho foi intitulado A recepção da figura de Marcel Duchamp em Historia abreviada de la literatura portátil.

Na realização deste primeiro trabalho, duas teorias sempre foram centrais. A primeira delas é a Estética da Recepção - trabalhada inicialmente por Hans Robert Jaussque possibilitou uma análise mais ampla desta narrativa autorreferencial, tanto por se distanciar de vertentes formalistas, principalmente pelo fato destas estudarem a literatura como uma representação autônoma, dissociada à sociedade, quanto por também se distanciar de teorias marxistas, como a Teoria do Reflexo. Afinal, pensando especificamente na obra de Vila-Matas, ambas vertentes acabam não sendo suficientes no momento de lidar com suas particularidades, dadas as razões que também são objeto de análise neste trabalho. 
Também foram indispensáveis estudos sobre a teoria da metalinguagem para analisar obras que, como as de Vila-Matas, se encontram dentro do modelo que a crítica denominou como metaliteratura. Desta forma, os estudos de tais obras sempre se imbricam aos estudos sobre intertextualidade, sendo que tanto no projeto de iniciação científica como nesta dissertação, os estudos de Gerárd Genette ocupam lugar de destaque.

Após o término do projeto de iniciação científica dei continuidade às leituras dos romances, ensaios e artigos escritos por Vila-Matas, constatando que ainda havia muito a ser explorado no que tange à análise destas obras e à forma como elas lançam e recebem luzes dos já mencionados referenciais teóricos centrais nesse percurso.

Em 2013, o autor publicou em seu blog um artigo intitulado Levedad, ida y vuelta, em que comenta a ligação entre Historia abreviada de la literatura portátil (1985), Bartleby y compañía (2000) e Aire de Dylan (2012). No artigo ele comenta que este último romance se trata de um dos textos mais pessoais que já escreveu. Nele, o autor revisita seu passado como o escritor, ainda iniciante, de Historia abreviada, lançando reflexões sobre seus anos de juventude e tentando resgatar um pouco de sua visão sobre literatura e arte naquele momento, abordando tanto os aspectos que o acompanharam até sua fase madura quanto os que foram ficando no meio ao caminho ao longo de sua trajetória.

Junto com Historia abreviada e Aire de Dylan, o autor insere Bartleby y compañía no que chama de "linha portátil" de sua produção literária e assim, a partir de sua visão de um experiente autor de 64 anos, ele analisa sua produção enquanto jovem de 37 e enquanto já maduro autor de 52. Deste modo, já se encontram aqui três homens diferentes, que foram muitos sendo um só.

Foi então com a leitura de Aire de Dylan que decidi continuar seguindo viagem junto a Vila-Matas e seus personagens itinerantes, desta vez no mestrado. Aqui sigo investigando, a partir da análise e comparação entre os romances Historia abreviada de la literatura portátil e Aire de Dylan, as múltiplas máscaras utilizadas por Vila-Matas em suas narrativas, tanto as máscaras que simulam o seu próprio rosto quanto as que toma emprestado de outros escritores e artistas, tais como Marcel Duchamp e Bob Dylan. Procuro analisar o salto inventivo dado por Vila-Matas na apresentação e representação destes artistas que, apesar de já possuírem inúmeras máscaras criadas por eles próprios, recebem também as concebidas pelo autor e seus leitores. 
Busco discutir como Vila-Matas utiliza estas máscaras de artistas que claramente o influenciaram com suas obras e com suas posturas como artistas. E sendo estes dois romances especialmente marcados pelo espírito duchampiano, resgato o termo figura de relevância, cunhado pelo também pesquisador da Recepção Karlheinz Stierle, para analisar como Vila-Matas utiliza essa figura para construir uma ideia de arte e acionar a imaginação e a experiência do leitor. Convido-lhes agora a embarcar nesta viagem e a participar deste baile de máscaras. 
1. O LEITOR E A OBRA VIVA 


\subsection{A obra de Enrique Vila-Matas pelo prisma da Recepção}

A Estética da Recepção surge ao final da década de 60 com a aula inaugural de Hans R. Jauss intitulada $O$ que é e com que fim se estuda a história da literatura? Desde esta palestra inicial de Jauss e a publicação de escritos de outros estudiosos da Recepção como Wolfgang Iser (1926 - 2007), Karlheinz Stierle (1936), Hans Ulrich Gumbrecht (1948), entre outros, esta teoria já se apresenta como uma proposta de releitura da tradição literária, questionando os métodos tradicionais de ensino e apresentando novas metodologias para o estudo da história da literatura, além de levantar problemáticas relacionadas ao modo como as vertentes formalistas ou marxistas abordavam a ideia de historicidade.

Ao propor reparos a estas teorias, Jauss suscita uma série de discussões que se tornam ricas contribuições a um de nossos interesses básicos: refletir sobre a relação entre Literatura e História, tomando-as como campos que se correlacionam e se influenciam

mutuamente. É com o objetivo de contribuir com estas discussões que destinamos esta parte do capítulo a analisar a importância destes reparos tanto às teorias formalistas e estruturalistas quanto à visão do materialismo histórico, além de refletir sobre a influência que estas buscas por estabelecimento de novos paradigmas exerceram na crítica brasileira. Para tanto, tomaremos como eixo central o problema da representação e do reflexo estético, analisando também o posicionamento de críticos estrangeiros e brasileiros frente a questões que, de diversas maneiras, se associam a este problema central.

Porém, antes de iniciar esta análise, é importante ressaltar que o objetivo não é o de polemizar, nem tampouco diminuir a relevância de outras teorias frente à Estética da Recepção. Trata-se de evidenciar esta teoria como um importante passo na evolução da teoria literária e como referencial teórico que melhor atende as especificidades do corpus literário deste trabalho.

Se, por um lado, a Teoria do Reflexo apresenta-se muitas vezes como referencial mais adequado para o estudo de um romance histórico por exemplo, por outro lado, a Estética da Recepção dialoga mais fluidamente com as teorias voltadas para o estudo de romances metalinguísticos e, assim, possibilita a abertura de outras perspectivas de discussão de obras autorreferenciais, como as de Vila-Matas.

$\mathrm{O}$ valor destas teorias que questionaremos aqui, sendo a teoria do reflexo estudada por Lukács a principal delas, reconhece-se inclusive na contribuição que estas oferecem 
aos estudos do grupo da Escola de Constança. Afinal, o que estes estudiosos buscam é construir um caminho que passa entre estas distintas perspectivas do marxismo e do formalismo, o que não ocorre sem que se tomem alguns préstimos de certas visões do texto literário que surgem a partir destas noções.

Em suma, o propósito é não nos atarmos a limites teóricos e buscarmos encontrar, no diálogo entre teorias distintas, aspectos que possam contribuir com nossas discussões. O próprio Jauss deixa claro que a Estética da Recepção busca sair destes dois impasses da teoria materialista e idealista, mas sem nunca se propor a ser uma teoria absoluta, nem tão pouco um parâmetro totalizante. Trata-se de um método parcial, construído a partir de pesquisas interdisciplinares e que muito pode agregar a este trabalho a partir de um tratamento dialógico que possibilita uma análise mais ampla da obra de Vila-Matas e aponta para novas possibilidades para se pensar na relação entre Literatura e História.

Em A história da literatura como provocação à teoria literária Jauss questiona:

Se, dessa perspectiva, voltarmos novamente o nosso olhar para o dilema comum à teoria literária formalista e à marxista, resultará daí uma conclusão que nenhuma delas tirou. Se, por um lado, se pode compreender a evolução literária a partir da sucessão histórica de sistemas e, por outro, a história geral a partir do encadeamento dinâmico de situações sociais, não haverá de ser possível também colocar-se a "série literária e a "não-literária" numa conexão que abranja a relação entre Literatura e história, sem com isso obrigar-se a primeira a, abandonando seu caráter artístico, encaixar-se numa função meramente mimética ou ilustrativa? (JAUSS, 1994, p. 20-21).

Tendo em vista o questionamento de Jauss, destinamos as próximas páginas à análise de como se dá o laço entre Literatura e História nas obras de Vila-Matas, sem que estas recorram a métodos puramente formalistas ou à tentativa de captar um reflexo estético da realidade, encontrando na Estética da Recepção uma teoria que atende às suas especificidades. 


\subsection{A função comunicativa da arte}

A primeira grande oposição de Jauss às teorias vigentes até o século XIX estava no papel limitado que o receptor desempenhava nelas. Em A história da literatura como provocação à teoria literária (1994) o autor afirma:

Leitores, ouvintes, espectadores - o fato público em suma, desempenha naquelas duas teorias literárias um papel extremamente limitado. A escola marxista não trata o leitor - quando dele se ocupa - diferentemente do modo como ela trata o autor: busca-lhe a posição social ou procura reconhecê-lo na estratificação de uma sociedade. A escola formalista precisa dele apenas como sujeito da percepção, como alguém que, seguindo as indicações do texto, tem a seu cargo distinguir a forma ou desvendar o procedimento (JAUSS, 1994, p. 22).

A desatenção à relevância que o receptor exercia na teoria literária neste momento pode ser observada também na crítica brasileira. Antonio Candido (1918), na introdução da sua Formação da literatura brasileira (1975), não deixa de considerar o "conjunto de receptores, formando os diferentes tipos de público, sem os quais a obra não vive" como elemento constituinte e indispensável do sistema literário - que em conjunto com os produtores e a partir de um mecanismo transmissor - dariam lugar "a um tipo de comunicação inter-humana, a literatura" (CANDIDO, 1975, p. 23). No entanto, o crítico tratará o estudo da recepção como fator secundário que fica a reboque da produção como elemento estruturante do sistema literário.

Em Literatura e sociedade (1965), Candido também evidencia o papel substancial que o leitor ocupa no sistema literário. Porém, ainda que seus trabalhos representem grandes avanços ao que se concerne à função comunicativa da arte e da literatura, justamente por defender a ligação indissolúvel entre autor, obra e público, este último nunca é posto em primeiro lugar desta relação, aparecendo apenas como elemento que realiza o autor:

O público dá sentido e realidade à obra, e sem ele o autor não se realiza, pois ele é de certo modo o espelho que reflete a sua imagem enquanto criador. Os artistas incompreendidos, ou desconhecidos em seu tempo, passam realmente a viver quando a posteridade define afinal o seu valor. Deste modo, o público é fator de ligação entre o autor e a sua própria obra (CANDIDO, 2006, p. 47).

Desta forma, o autor ainda é tido como elemento que mais exerce influência no processo comunicativo. E mesmo ao afirmar que esta ordem de ascendência pode variar, 
com a série autor-público-obra se convertendo em autor-obra-público, ou obra-autorpúblico, o público nunca assume o papel principal desta relação.

É visando analisar principalmente este processo que Jauss se preocupa vigorosamente com a função comunicativa da arte, o que é mais um elemento que aproxima o estudo da recepção com o estudo de outras áreas do conhecimento. Neste caso, relaciona-se também com teorias linguísticas que apontam que por trás de todo texto há um ato comunicativo. Inclusive os textos ficcionais apresentam questões exigindo um diálogo com o leitor, que não necessariamente se dá no momento imediato da leitura.

O destaque que o crítico alemão destina à função comunicativa da experiência estética permeia toda a sua obra, tanto que é questionando o que o estudo desta experiência pode agregar à teoria contemporânea da arte que ele inicia suas Colocações gerais sobre a Estética da Recepção:

\footnotetext{
Que significa a experiência estética, como ela tem se manifestado na história da arte, que interesse pode ganhar para a teoria contemporânea da arte? Por muito tempo, a teoria estética e a hermenêutica literária deram pouca atenção a estas questões. Na reflexão teórica sobre a arte, quer a anterior, quer a posterior à constituição da estética como ciência autônoma, tais perguntas permaneciam ocultadas pelos problemas legados pela ontologia e pela metafísica platônica do belo. A polaridade entre arte e a natureza, a correlação do belo com a verdade e o bem, a congruência da forma com o conteúdo, da forma com a significação, a relação entre imitação e criação eram as questões canônicas supremas da reflexão filosofia da arte. O legado platônico, muitas vezes não admitido, mostra-se ainda em curso na filosofia contemporânea da arte sempre que se concede à verdade, manifestada pela arte, a primazia sobre a experiência da arte, na qual se exterioriza a atividade estética como obra dos homens. Por isso a pergunta pela práxis estética, de importância decisiva em toda arte manifestada como atividade produtora, receptiva e comunicativa, permanece, em grande parte, não esclarecida e precisa ser hoje recolocada (JAUSS et al. 1979, p. 71).
}

Ao comentar a importância da experiência literária, o autor já levanta questões que posteriormente serão discutidas por ele sobre esta rede de relações complexas da literatura, que tal como em Candido é formada por um princípio triádico em que se estabelece uma ponte entre produção (poiesis), recepção (aisthesis) e comunicação (katharsis), os três elementos que constituem a totalidade da experiência estética.

Porém, na visão de Jauss, como também é colocado em $O$ prazer estético e as experiências fundamentais da poiesis, aisthesis e katharsis (1979), estas três instâncias se relacionam de maneira dinâmica, em que cada uma destas categorias exerce funções autônomas, estabelecendo relações de sequência, mas não de hierarquia. 
No final das contas, estamos lidando com uma comunicação aberta, na qual se pode observar a função comunicativa da experiência estética decorrendo não necessariamente da função catártica, mas da aisthesis, por exemplo, ou esta se convertendo em poiesis, já que "o observador pode considerar o objeto estético como incompleto, sair de sua atitude contemplativa e se converte cocriador da obra" (JAUSS, 2002 p. 102-103). Deste modo, esta complexa relação triádica passa a ser vista mais flexivelmente, fato que contribui com a grande visibilidade que o leitor passou a ter nos estudos de teoria literária.

Se procuramos exemplos concretos destes espaços que transformam o leitor em cocriador dentro da literatura, podemos encontrar muitos na obra de Vila-Matas. Em Bartleby y compañía, por exemplo, o leitor se apropria das informações presentes nas notas de pé de página, para imaginar o que diria aquele texto inexistente.

Outro exemplo é a supressão de páginas inteiras em A vida e a obra do cavalheiro Tristram Shandy (1759), de Sterne, devido a seu narrador compreender que, por serem páginas escritas com qualidade muito superior as demais, acabaria desequilibrando a narrativa. Ao leitor resta imaginar o conteúdo e o estilo destas páginas.

No entanto, há ainda espaços mais sutis e não tão literais quanto estes. Quando Vila-Matas seleciona uma fotografia de Man Ray (1890-1976), por exemplo, criando para ela todo um contexto que se encaixa à sua narrativa, ele abre espaço em sua obra (que o leitor pode preencher através do auxílio da fotografia) e também lança novas possibilidades de interpretação para a fotografia em questão.

Deste modo, a busca por uma teoria da literatura que fosse capaz de lançar luzes sobre este dinamismo de processo de produção e recepção que resultasse nesta relação flexível entre autor, obra e público, teve como aporte teórico os pressupostos da hermenêutica filosófica de Hans-Georg Gadamer (1900-2002). A hermenêutica da pergunta e resposta foi indispensável no objetivo dos teóricos da recepção de estudarem a função comunicativa da literatura. Sobre esta teoria, Antoine Compagnon (1950) comenta:

Toda interpretação é então concebida como um diálogo entre passado e presente, ou uma dialética da questão e da resposta. A distância temporal entre o intérprete e o texto não precisa ser preenchida, nem para explicar nem para compreender, mas com o nome de fusão de horizontes torna-se um traço inelutável e produtivo da interpretação: esta, como ato, por um lado, faz o intérprete ter consciência de suas idéias antecipadas, e por outro, preserva o passado no presente. A resposta que o texto oferece depende da questão que dirigimos de nosso ponto de vista histórico, mas também de nossa faculdade 
de reconstruir a questão à qual o texto responde, porque o texto dialoga igualmente com sua própria história (COMPAGNON, 2010, p. 63).

Esta ideia de fusão de horizontes proposta por Gadamer é a de que, no ato de leitura, o horizonte da literatura do passado se funde com a do presente. Porém esta fusão de horizontes muitas vezes não ocorre plácida e esquematicamente, justamente porque nem sempre esta hermenêutica de pergunta e resposta resulta em um diálogo fluido, já que tanto as perguntas como as respostas em princípio estão desarticuladas. Em Verdade e método, Gadamer afirma:

É verdade que um texto não nos fala como o faria tu. Somos só nós, que compreendemos, que temos de trazê-lo à fala a partir de nós mesmos. Mas já vimos que esse trazer-à-fala, próprio da compreensão, não é uma intervenção arbitraria de uma iniciativa pessoal, mas refere, por sua vez, como pergunta à resposta latente do texto. A latência de uma resposta pressupõe, por sua vez, que aquele que pergunta foi atingido e se sente interpelado pela própria tradição. Esta é a verdade da consciência da história efeitual. Na medida em que nega o fantasma de um esclarecimento total, e justo por isso, a consciência dotada de experiência histórica está aberta para a experiência da história. Descrevemos sua maneira de realizar-se como a fusão de horizontes do compreender que faz a intermediação entre o texto e seu intérprete (GADAMER, 2005, p. 486).

Também com o auxílio desta hermenêutica, o grupo da escola de Constança dá importantes passos para a evolução da teoria literária. Como colocou Jauss, esta teoria surge como "oportunidade de uma nova teoria da literatura, exatamente não no ultrapasse da história, mas sim na compreensão ainda não esgotada da historicidade característica da arte e diferenciadora de sua compreensão" (JAUSS et al. 1979, p.71). Assim, surge um estudo que aponta para o fato de a teoria geral da literatura ter uma historicidade sobre a qual a própria teoria literária e literatura podem refletir. Esta perspectiva abre importantes horizontes para a discussão de obras como as de Vila-Matas, que estão sempre levantando questões sobre a historicidade da literatura.

Ainda que o objeto central de pesquisas realizadas por teóricos abordados aqui seja a literatura, muitas de suas conclusões podem ser aplicadas também às demais linguagens artísticas. Afinal, nestas também se pode evidenciar a interação entre presente e passado, e o dinamismo entre suas próprias histórias e a história da humanidade, de maneira, até certo ponto, similar com o que acontece nas narrativas de Vila-Matas. 
Ao analisarmos obras de artistas como Duchamp, considerando a hermenêutica da pergunta e resposta, também podemos perceber a fusão de horizontes tanto da obra com seu intérprete quanto da obra do presente com obras do passado.

Tomemos como exemplo a manipulação da cópia do retrato que o francês realizou de Mona Lisa em L.H.O.O.Q. Ao se deparar com esta obra, o intérprete pode criar uma série de perguntas que variam de acordo com sua experiência. O receptor familiarizado com a produção de Duchamp e de Leonardo da Vinci poderá questionar: Por que Duchamp desenhou bigodes em Mona Lisa? Além dos bigodes, quais outros aspectos da obra transmitem um desejo por parte do artista francês de burlar com a tradição artística? Pode se tratar de um homem disfarçado de mulher? Existe um discurso por trás da obra que vá além da proposta provocadora de ruptura com os moldes clássicos?

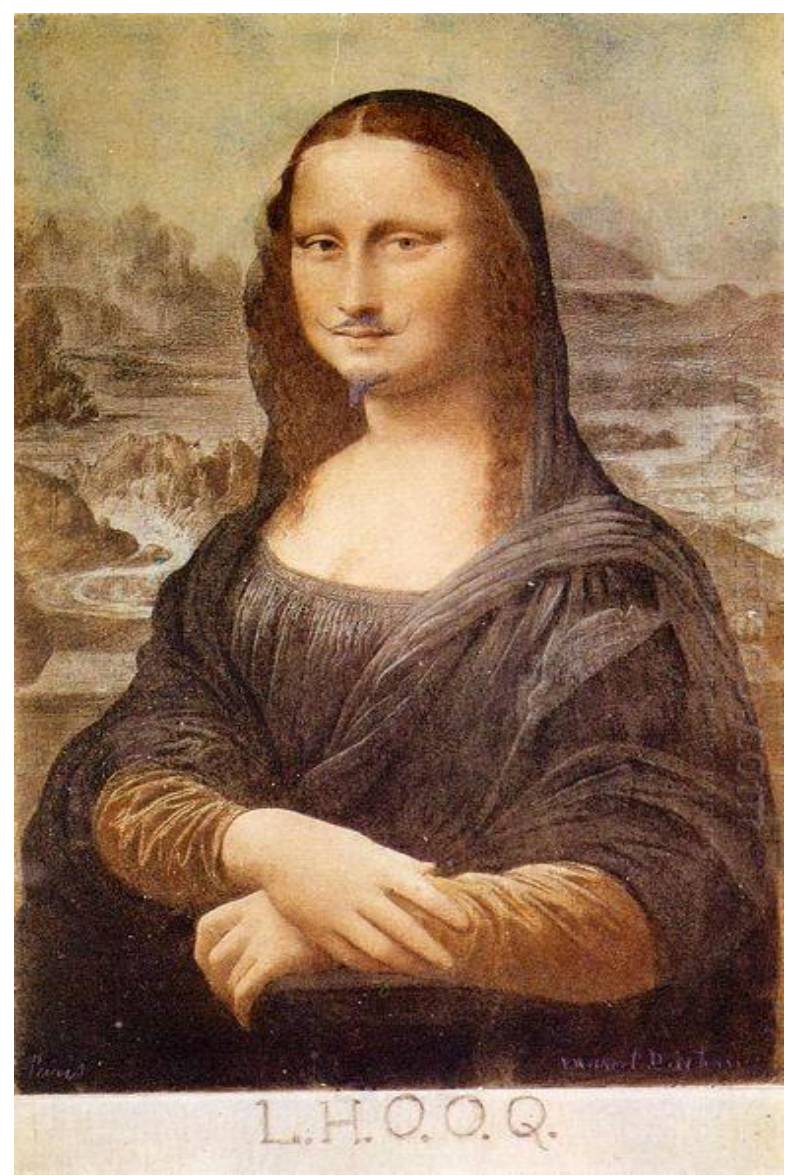

Figura 1 - DUCHAMP. L.H.O.O.Q. 1919. Ready-made retificado.

Além da obra em si, outros elementos são relevantes no direcionamento de perguntas ao receptor. Quando Genette cria o termo paratexto para designar os elementos periféricos que exercem influência na recepção do texto, ele se refere ao título como sendo um dos mais relevantes destes elementos. 
Outra vez, aplicando estas teorias na análise da recepção das obras de Marcel Duchamp, o título de L.H.O.O.Q tem sua proeminência elevada por estar escrito na própria obra. Assim como ocorre em diversas obras do francês, o título se torna mais um jogo entre os tantos que insere em suas produções. Afirmava ele: "Geralmente, os títulos me interessavam muito. Nesse momento me sentia literário. As palavras me interessavam"1 (DUCHAMP apud CABANNE, 1967, p.34). ${ }^{2}$

No caso específico desta obra, não se trata exatamente de um jogo de palavras, mas de um jogo fonético, visto que a sigla, quando pronunciada em francês, soaria como "elle a chaud au cul", que em uma tradução livre ficaria "ela tem fogo no rabo". Também em entrevista a Cabanne, Duchamp declara que nestas letras não há outro significado senão o humorístico e que lhe agrada "esse tipo de jogos, porque penso que podem ser feitos muitos. Ao se ler as letras em francês, e em qualquer outro idioma, se chega a coisas surpreendentes"3. No entanto, apesar da declaração de Duchamp, o receptor consciente deste jogo provavelmente o considerará no momento de formular perguntas à obra.

Vale ressaltar que o diálogo entre passado e presente se concebe nessa obra não somente por se tratar de uma obra mais atual que se propõe uma releitura de uma mais antiga, afinal, este diálogo ocorre mesmo em obras em que as referências e influências do autor não aparecem explicitamente. O diálogo se dá também, a partir do momento em que um intérprete do presente traz o passado para o seu tempo e lança questões a serem respondidas pela obra que, por sua vez, apresenta respostas que estão em consonância com as perguntas lançadas pelo receptor a partir de sua perspectiva histórica.

Obras como esta de Duchamp ou toda a narrativa vilamatiana são manifestamente marcadas pela intertextualidade, tomando o conceito de Genette, segundo o qual a intertextualidade é uma " relação de copresença entre dois ou mais textos [...] a presença efetiva de um texto em outro"4. Assim, tais obras carregam consigo não somente a sua própria historicidade e história de como foram lidas de determinadas formas por leitores de determinados períodos, mas também dialogam com as obras com as quais estabelecem o diálogo intertextual.

\footnotetext{
${ }^{1}$ Todas as citações traduzidas do espanhol neste trabalho são resultado de livre interpretação. Em nota de rodapé, seguirão os originais da versão das obras dos autores ou a tradução em língua espanhola.

2 "Generalmente, los títulos me interesaban mucho. En ese momento me ponía literario. Las palabras me interesaban” (DUCHAMP apud CABANNE, 1967, p.34).

${ }^{3}$ ese tipo de juegos, debido a que creo que pueden hacerse muchos. Al leerse simplemente las letras en francés, y en cualquier otro idioma, se llega a cosas sorprendentes. Leer las letras es muy divertido (DUCHAMP apud CABANNE, 1967, p.34).

4 "relación de copresencia entre dos o más textos [...] la presencia efectiva de un texto en otro" (GENETTE, 1982/1989, p. 10).
} 
De um lado, as obras anteriores que se manifestam em novos textos podem ter muito a acrescentar na recepção destes, de outro, como acentua Borges em Kafka y sus precursores (1952), o inverso também ocorre, de modo que os novos textos também lançam luzes sobre os textos que evocam. Borges exemplifica:

O poema Fears and Scruples de Browning profetiza a obra de Kafka, mas nossa leitura de Kafka refina e desvia sensivelmente nossa leitura do poema. Browning não o lia como o lemos agora. No vocabulário crítico, a palavra precursor é indispensável, mas seria necessário purifica-la de toda conotação de polêmica ou rivalidade. $\mathrm{O}$ fato é que cada escritor cria seus precursores. Seu trabalho modifica nossa concepção do passado, como haverá de modificar o futuro (BORGES, 1952, p. 711-712). ${ }^{5}$

Em Flores da escrivaninha (1990), Leyla Perrone-Moisés relembra o ensaio de Borges e assinala:

[...] Uma obra forte nos obriga a uma releitura de todo o passado literário, onde passaremos a encontrar não as fontes daquele novo autor, mas obras que se tornam legíveis e interessantes porque existe esse autor moderno; obras que passam a ser, então, "precursoras" dessa nova obra [...] Para Borges, portanto, a tradição é uma questão de leitura, de recepção, e como essa recepção se transforma em cada momento histórico, a tradição está sempre sujeita a uma revisão (PERRONE-MOISÉS, 1990, p. 95).

Desta forma, obras como a L.H.O.O.Q de Duchamp e textos como os do próprio Borges, marcados pela copresença de outros tantos, estão repletos de propostas de releituras de obras e tradição.

Assim, para compreender a dimensão duchampiana na produção do autor catalão, especialmente nos romances Aire de Dylan e Historia abreviada de la literatura portátil, é necessário considerar não somente a recepção externa, ou seja, a recepção dos romances em si, mas também as recepções imediatas, aquelas que já estão presentes no texto, como as leituras que o próprio Vila-Matas apresenta sobre a obra e a figura de Duchamp. Através desta releitura, o autor conecta suas ideias de literatura e arte com os movimentos vanguardistas, recebe e lança luzes sobre eles, criando mais um canal de comunicação entre passado, presente e futuro.

\footnotetext{
5 "El poema Fears and Scruples de Browning profetiza la obra de Kafka, pero nuestra lectura de Kafka afina y desvía sensiblemente nuestra lectura del poema. Browning no lo leía como ahora nosotros lo leemos. En el vocabulario crítico, la palabra precursor es indispensable, pero habría que tratar de purificarla de toda connotación de polémica o rivalidad. El hecho es que cada escritor crea sus precursores. Su labor modifica nuestra concepción del pasado, como ha de modificar el futuro" (BORGES, 1952, p. 711-712).
} 


\subsection{O problema da Representação e do reflexo estético}

Quando plausível, o impossível se deve
preferir a um possivel que não convença.

Aristóteles

Os problemas referentes aos distintos modos de estudar e refletir sobre a função comunicativa da arte e de especular sobre a relação entre Literatura e História também se relacionam com o problema da representação e do reflexo. À vista disto, agora nos propomos a colocar as ideias de autores que se dedicaram à Estética da Recepção, e algumas teorias paralelas a ela, frente as ideias de György Lukács, cujo trabalho constitui um dos mais proeminentes estudos sobre a teoria do reflexo.

De acordo com a visão de Lukács, uma das mais importantes funções da arte é refletir esteticamente a vida. $\mathrm{O}$ artista deve procurar o que de essencial há na vida cotidiana, para então, representar em sua obra uma realidade concreta. Esta representação se dá por meio do reflexo estético, e se este se perde, a realidade não é transmitida corretamente. O reflexo, para não atuar como força reificadora, precisa ser muito mais do que uma mera cópia e representar o típico, ou seja, deve contemplar as contradições que aparecem dispersas na cotidianidade e reduzi-las no mundo artístico para que então possam ser vistas de forma intensificada.

A Estética da Recepção, como mencionado anteriormente, pretende superar esta visão da literatura como reflexo ou como ente independente de outros processos ou séries históricas relacionadas à história literária. Mas, apesar da distância que a teoria da recepção procura estabelecer desta representação marxista, teóricos como Jauss e Gumbrecht não deixam de apontar para os meios pelos quais a arte abre janelas para outros mundos. Gumbrecht, por exemplo, trabalha com a ideia de Stimmung, de se considerar o texto como uma espécie de clima e atmosfera. Trata-se de uma teoria que defende que uma obra de arte seja analisada não apenas pelos sentidos que apresenta, mas também por aquilo que ela provoca no espectador.

A ideia básica é propor uma mimese mais aberta e menos limitadora do que esta que sugere a representação de um reflexo. Ideia com a qual o crítico brasileiro Luiz Costa Lima (1937) está de acordo. O que Costa Lima sugere é que "a experiência ficcional supõe a experimentação do que não se conhece, empreendida, contudo, com balizas do que o criador e o receptor tomam como verdadeiro" (COSTA LIMA, 1995, p. 306). Segundo esta ideia, a verossimilhança surge do pacto de leitura entre o autor, o leitor e 
também o crítico, considerando o que estes tomam como verdade. Deste modo, a ficção não poderia simplesmente representar a realidade. A verdade se constitui aqui, no ponto de vista da representação, como uma verossimilhança. Esta ideia se conecta com a ideia de intimidade e estranhamento proposta por Stierle, que também não acredita na ideia da literatura como reflexo:

\begin{abstract}
A ficção não é um reflexo do mundo, nem a representação de um outro bem diverso. Ao contrário, ela descreve, numa configuração sempre nova, a tensa mediação entre dois campos, à medida em que os reúne em uma figura de relevância. É nessa fronteira que se articulam as figuras de experiência possível, a saber, na distância insuprimível de uma horizontidade estética, que, ao mesmo tempo se define pela intimidade de uma concepção prévia do mundo e pela estranheza do outro, oposto àquele (STIERLE et al. 1979 p. 161).
\end{abstract}

Tendo a obra de Vila-Matas como perspectiva, a ideia de considerar a literatura como um reflexo de uma realidade parece ainda mais limitadora, primeiro por conta de seu caráter autorreferencial, segundo porque nela ficção e realidade se encontram praticamente no mesmo patamar. 


\subsection{Literatura, realidade e imaginação}

Lo nuevo, lo creador $y$, por tanto, lo verdaderamente revolucionario es ruptura, negación. [...] se puede hoy no hacer poesía surrealista, pero no se puede hacer poesía como si el surrealismo no hubiera existido; se puede hoy hacer un verdadero arte realista -y subrayo lo de verdadero para marcar la diferencia con lo que en nombre del realismo es la negación de éste y del arte mismo. ${ }^{6}$

Adolfo Sánchez Vásquez

Para Lukács, a grande arte é sempre aquela que capta um reflexo estético da vida. É a criação de um novo mundo onde aquilo que aparece disperso na vida cotidiana, principalmente devido à reificação, é novamente unificado neste novo universo, fazendo com que o homem volte a se reconhecer como humano ao identificar a si e a sociedade em que vive neste reflexo artístico.

Este mundo particular, que reduz os diversos aspectos da realidade para ampliálos dentro de seu próprio universo, consegue conglobar aquilo que está fragmentado, na medida em que une em seu universo a aparência e sua essência, revelando esta conexão para o receptor. Deste modo, ao contrário do reflexo científico, que despreza a singularidade e consequentemente desantropomorfiza a realidade, o reflexo artístico tem a grande função de contribuir para a humanidade perceber a necessidade e então iniciar a busca por sua emancipação.

Em Narrar ou descrever? Lukács afirma:

$\mathrm{O}$ verdadeiro conhecimento das forças motrizes do processo social e o reflexo exato, profundo e sem preconceitos da ação dêste processo sôbre a vida humana, assumem a força de um movimento: um movimento que representa e esclarece a unidade orgânica que liga a normalidade à exceção (LUKÁCS, 1965, p. 57).

\footnotetext{
6 “O novo, o criador e, portanto, o verdadeiramente revolucionário é ruptura, negação. [...] se pode hoje não fazer poesia surrealista, mas não se pode fazer poesia como se o surrealismo não houvesse existido; se pode hoje fazer uma verdadeira arte realista - e destaco o verdadeiro para marcar a diferença com o que em nome do realismo é a negação do mesmo" (VÁZQUEZ, 1964, p. 12 - 13).
} 
Portanto, para que este objetivo de guiar o homem até sua emancipação seja alcançado, a obra de arte precisa refletir a realidade, pois somente uma obra realista seria capaz de indicar os problemas da vida em uma sociedade fetichizada, motivar a humanidade a não os crer como imutáveis e agir para enfim transformá-los. Ou seja, para Lukács, existe uma característica indispensável para a verdadeira obra de arte: o reflexo da vida cotidiana. Consequentemente, a arte não pode estar desvinculada da realidade.

Se, por um lado, Lukács defende que somente o realismo e a arte que reflete o real são capazes de defender a emancipação humana, por outro, Vila-Matas sempre viu essa tentativa de mimetizar o real como uma atitude que limita a arte e até mesmo como um fator que, ao contrário do que esperam os artistas realistas, dificulta a aproximação da obra com a realidade.

Para Vila-Matas, um dos grandes trunfos da arte é a imaginação, o que inclui tanto a capacidade inventiva do artista quanto a criatividade do receptor que preenche os vazios presentes na obra. Em um de seus artigos publicados no jornal El País ${ }^{7}$, Un atisbo de la realidad, o espanhol comenta sobre a fonte de inspiração dos escritores, afirmando que "a maioria dos narradores de histórias trabalham mais com a imaginação que com a pouca experiência que tem [...] apenas precisamos de vislumbre de realidade, porque a imaginação faz o resto" " Em outro artigo intitulado Dominio de la parte inventada, o autor ainda destaca:

Um romance "baseado em fatos reais" não significa nada, porque toda obra de ficção, por fantástica que seja, tem sempre uma raiz na realidade. [...] se algo vai ficar no futuro do que fazemos será a parte inventada, e se algo terá beleza será essa parte inventada. ${ }^{9}$

Então, enquanto Lukács aponta para a importância do realismo na ficção, VilaMatas aponta a imaginação como um dos principais elementos que a constituem. Enquanto Lukács defende uma literatura que se converte em um espelho que reflete mimeticamente a realidade, Vila-Matas cria obras em que os muros que separam realidade

\footnotetext{
${ }^{7}$ Há diversos artigos de Vila-Matas a serem mencionados neste trabalho. Todos podem ser encontrados em seu blog, no endereço: http://www.enriquevilamatas.com/blogs.html.

8 "la mayoría de los narradores de historias trabajan más con la imaginación que con la poca experiencia vital que tienen [...] apenas necesitamos de un atisbo de realidad, porque la imaginación hace el resto" (VILA-MATAS, 2009).

9 "Una novela "basada en hechos reales" no significa nada, porque toda obra de ficción, por fantástica que sea, tiene siempre una raíz en la realidad. [...] si algo va a quedar en el futuro de lo que hacemos será la parte inventada, y si algo tendrá belleza será esa parte inventada" (VILA-MATAS, 2016).
} 
e ficção são derrubados e uma passa a fazer parte da outra de maneira indissolúvel. Em Hambre de realidad, artigo em que comenta o livro de mesmo nome de David Shields, o espanhol afirma: "a ficção literária faz parte da verdade: o que alguém imagina é tão real como a vida, pois faz parte dela. A vida, além disso, como a própria natureza, é enganosa"10.

Este é mais um de seus textos em que o autor defende a imaginação em detrimento de uma literatura fiel à realidade. Aqui, ele afirma que tanto os escritores que narram desde fora, utilizando um personagem, quanto os que escrevem como se os relatos formassem parte de suas vidas, se aproximam bem mais da verdade do que aqueles escritores cujos relatos poderiam ser comprovados pela imprensa, por exemplo.

São muitos os aspectos da literatura, dos leitores e da sociedade espanhola de maneira geral criticados por Vila-Matas. Uma das críticas frequentes é sobre a dificuldade dos espanhóis de se libertarem das heranças franquistas e aceitarem novas propostas de literatura, o que explicaria o fato de sua obra ser antes lida e valorizada na América Latina do que na Espanha. Segundo o autor, ainda hoje a literatura espanhola é realista e carece de imaginação.

No entanto, Vila-Matas desde seus primeiros trabalhos, seguiu o caminho totalmente oposto ao que ele afirma que a maioria considerável de seus conterrâneos seguiu e segue até hoje. Desde cedo o autor optou pelo lado da insolência, defendendo rupturas, caminhando na direção contrária à tradição. E ao trilhar esse caminho, evocou como companhia de viagem alguns dos nomes que melhor representam o espírito da insolência, entre eles Francis Picabia (1879 - 1953).

Picabia foi um dos grandes inspiradores de Duchamp. Em Conversaciones con Marcel Duchamp (1967), Pierre Cabanne (1921-2007) questiona ao francês se o encontro com Picabia foi determinante na ruptura que ele estava a ponto de levar a cabo. Duchamp confirma e comenta que o espírito surpreendente do amigo o motivou em muitos aspectos, entre eles o fato de Picabia ser um negador: "Com ele se tratava sempre de $<<$ sim, mas $>>$, $<<$ não, mas >>. Dissesse o que dissesse ele sempre contradizia. Era seu jogo, do qual talvez nem sequer fosse consciente" 11 .

\footnotetext{
10 "la ficción literaria forma parte de la verdad: lo que uno imagina es tan real como la vida, pues forma parte de ella. La vida, además, como la naturaleza misma, es engañosa" (VILA-MATAS, 2015).

11 "Con él se trataba siempre de <<sí, pero〉>, <<no, pero〉>. Se dijera lo que se dijera siempre contradecía. Era su juego, del que tal vez ni siquiera era consiente. Evidentemente era preciso defenderse un poco" (DUCHAMP apud CABANNE, 1967, p. 24).
} 
Ao contrário do que afirma Duchamp sobre Picabia, Vila-Matas sempre percebeu que se contradizia. Mais do que isso, desde cedo ele sempre lutou pelo direito de contradizer tanto a si próprio quanto aos outros. Assim, o autor fez da contradição o terreno onde construiu e constrói suas narrativas. A contradição, a negação e a imaginação são artifícios que ele utiliza para chegar à realidade por meios opostos aos do realismo.

Vale ressaltar que quando critica o realismo, Vila-Matas não se refere ao Realismo como o período literário do século XIX, mas a toda literatura que se propõe a abordar a realidade tal como ela é. Por um lado, Lukács e Vila-Matas concordam que o método descritivo gera obras que se tornam meras cópias da realidade, transformando o homem em natureza morta. Ainda em Narrar ou descrever salienta:

\footnotetext{
A concepção marxista do realismo nada tem a ver com a cópia fotográfica da vida cotidiana. A estética marxista se limita a desejar que a essência individualizada pelo escritor não venha representada de maneira abstrata $e$, sim, como essência organicamente inserida no quadro da fermentação dos fenômenos a partir dos quais ela nasce. [...] até mesmo o mais extravagante jogo da fantasia poética e as mais fantásticas representações dos fenômenos são plenamente conciliáveis com a concepção marxista do realismo (LUKÁCS, 2010 p.27/28).
}

Porém, ainda que Lukács se preocupe sempre em demonstrar o quanto é complexo o processo de criação de uma obra realmente comprometida em captar o reflexo estético da vida cotidiana, tornando-se assim uma obra realista, segundo a sua concepção do termo, ele nunca renuncia a ideia de que mesmo as obras mais fantásticas sejam um espelho mimético da realidade.

Já nos textos de Vila-Matas a ficção nunca é este espelho que se posiciona frente à realidade gerando seu reflexo estético. Em suas obras, realidade e ficção convivem de mãos dadas no mesmo espaço; a ligação entre ambas é tão estreita que passa a ser impossível dizer onde começa uma e onde termina a outra.

Em entrevista a Christian Elguera Olortegui, o autor esclarece que sua intenção não é se distanciar do realismo, mas criar um realismo diferente do convencional. Sobre este aspecto de suas obras ele afirma: "Eu utilizei uma ideia diferente de realismo, que vem dada por um ponto de vista de meus narradores, um ponto de vista intransferível a qualquer outro escritor. Ler meu trabalho me parece que equivale a encontrar uma 
realidade diferente" 12 . Deste modo, os próprios romances de Vila-Matas já acabam criando uma realidade distinta, afinal, segundo a visão do autor, a própria ficção já é uma realidade em si, não tendo o dever de refletir outra.

Dois aspectos são determinantes ao se contrapor a poética dos textos de VilaMatas à Teoria do Reflexo: de um lado a preferência pelo amplo uso da imaginação, de outro, o caráter autorreferencial destes textos. Como evidencia o próprio título de Narrar ou descrever? Em seus estudos Lukács prioriza a análise da função referencial da linguagem, assim, enquanto se discute amplamente os métodos narrativos e descritivos, por exemplo, não há muito espaço para a análise da função autorreferencial e para a discussão sobre estas obras literárias que criam suas realidades em sua própria dimensão.

Mastroianni-sur-mer, um dos ensaios reunidos em El viento ligero en Parma (2008), é mais um texto em que Vila-Matas defende uma literatura pautada em suas questões internas: "Quem hoje em dia continua acreditando que é necessário subordinar a narração a objetivos extraliterários merece que lhes declare guerra total: guerra total contra uma literatura que não confia em si própria"13. Aqui, o autor se posiciona contra a habitual visão de que somente tem valor a arte que provoca reflexões sobre questões sociais e toda a sua realidade externa.

Em síntese, Vila-Matas torce sempre pela vitória da parte artística. Embora Lukács defendesse que a arte panfletária fosse ineficaz e se distanciasse do realismo, para ele a literatura deveria estar sempre comprometida em levantar questões políticas e sociais. $\mathrm{O}$ autor não tem esse objetivo, mas não deixa de alcançá-lo.

Ainda que o centro de suas discussões seja a própria arte, em meio a suas obras diversas questões históricas e sociais se camuflam com os temas abordados, até porque falar sobre arte é falar de sua relação com a humanidade, ainda que indiretamente. Porém, Vila-Matas nunca privilegia a realidade e os aspectos que dela uma obra literária pode extrair, sua torcida é pela vitória da imaginação.

\footnotetext{
12 "Yo he utilizado una idea diferente de realismo, que viene dada por el punto de vista de mis narradores, un punto de vista intransferible a cualquier otro escritor. Leerme me parece que equivale a encontrar una realidad distinta" (Vila-Matas. "Entrevista a Enrique Vila-Matas". Olortegui, Christian E.).

13 "Quienes hoy en día siguen creyendo que hay que subordinar la narración a objetivos extraliterarios merecen que se les declare la guerra: guerra total contra una literatura que no confía en sí misma" (VILAMATAS, 2008, p. 38).
} 


\subsection{A recepção dos textos ficcionais}

Stierle foi um dos teóricos da recepção que se dedicou especificamente à recepção dos textos ficcionais. Pensando nas particularidades da relação que o receptor estabelece com estes textos não pragmáticos, ele busca desenvolver uma teoria formal da ficção. Em Que significa a recepção dos textos ficcionais? Stierle traz diversas exemplificações a fim de pensar a recepção da literatura e da arte a partir de textos concretos. Este texto, na verdade, não se configura como uma análise de texto literário, mas sim como uma proposta de reflexão sobre formas de se ler certo tipo de texto.

O primeiro ponto a se considerar sobre as singularidades da recepção seria então questionar a especificidade da sua constituição e, do mesmo modo que Jauss, Stierle afirma que para isso é necessária uma abordagem interdisciplinar do tema, que trate as questões literárias somando a elas o que outras diversas áreas do conhecimento, como linguística, sociologia, psicologia, entre outras, podem agregar. Este caráter interdisciplinar proposto pelos teóricos da recepção é um dos fatores que possibilita a abertura para que elementos externos à literatura sejam também analisados como constituintes do texto e fatores que exercem influência em sua recepção imediata.

Stierle aponta ainda para a necessidade de se refletir sobre a recepção ingênua do texto pragmático que, segundo ele, é entendido como forma elementar de recepção comum a todos os textos. Ele afirma:

\footnotetext{
Com a passagem para o campo dos textos ficcionais, dever-se-ia discutir a recepção ingênua, aí também possível, que compreende o texto ficcional como quase pragmático e, assim, o toma como ilusão. Diante disso, deve-se mostrar a possibilidade de uma recepção que surge das condições da própria ficção. Se a ficção for interpretada como uma indicação para o cumprimento de uma figura de relevância, exigida por sua forma, daí decorrerá a pergunta sobre até que ponto o leitor porá em jogo o mundo como horizonte da ficção e quais as consequiências disso quanto a distância histórica entre o texto e a recepção. Por fim, com a pergunta sobre o mundo como horizonte da ficção, coloca-se a pergunta complementar sobre a função vital (lebensweltlich) da ficção, isto é, sobre a ficção como "horizonte de mundo" (STIERLE et al. 1979, p. 122. Grifos do autor).
}

Aqui, mais uma vez pode-se estabelecer uma comparação com a ideia de representação estudada por Lukács. De acordo com o teórico húngaro, a arte surge da vida cotidiana sendo que o verdadeiro artista é responsável por diluir diversos aspectos 
desta vida em uma obra, aspectos que então serão intensificados em outro mundo criado pela arte, bem como os sentidos do receptor. Note-se que esta espécie de duplicação do real operado pela obra de arte se dá nos distintos teóricos desde perspectivas distintas sobre a linguagem.

Este modo de pensar a cotidianidade como objeto máximo da representação artística, de certa forma se aproxima desta ideia de se ter o mundo como horizonte da ficção e de se considerar a realidade como algo que forma um reflexo que pode ser convertido em ficção.

Por outro lado, quando levantamos a questão sobre a ficção como horizonte de mundo, abrimos portas para análises de obras autorreferenciais que, mesmo tomando como tema principal o próprio universo da criação artística, não deixam de se relacionar com a vida. Muito pelo contrário, afinal, se como o próprio Lukács coloca, a vida é o principal material da arte, refletir sobre arte pode ser um dos mais eficazes métodos de se refletir sobre a vida, de modo que quando a arte se volta para si mesmo, faz refletir não só sobre questões técnicas, mas também levanta questões sobre sua própria historicidade e, consequentemente, sobre a relação que ela estabelece com a vida ao longo de toda a história da humanidade.

Esta inversão de pensar a ficção como horizonte do mundo, indo além da possibilidade de tê-lo como horizonte da ficção, também pode conectar-se com a reversão entre tema e horizonte, já que em um primeiro momento, a leitura evoca conceitos previamente formados, a experiência do leitor, e os elementos que possibilitam a apropriação do texto. Porém, em um segundo momento, há uma reversão entre a apropriação e o horizonte de mundo, e é desta forma que se constitui o que Stierle caracteriza como movimento centrífugo. No entanto, o teórico ressalta que:

A auto-reflexividade da ficção não implica a sua autonomia quanto ao mundo real. O mundo da ficção e o mundo real se coordenam reciprocamente [...] O âmbito da recepção dos textos ficcionais demarca-se apenas na apreensão desta dupla perspectiva (STIERLE, 2002, p. 155).

Observa-se que, em diversos momentos, Stierle embasa seus argumentos ou toma préstimos de teorias linguísticas. A partir de uma perspectiva semiótica, ele comenta que o primeiro passo da recepção ocorre quando o leitor empreende um complexo processo de tradução do texto. No caso dos textos pragmáticos, a tendência do leitor é estabelecer uma relação direta com a realidade, enquanto que na leitura de um texto ficcional o jogo que o leitor empreende é completamente distinto, já que esta transposição se torna 
impossível. Desta maneira, os textos pragmáticos estariam sempre direcionando o leitor para fora do texto, enquanto que o texto ficcional o emerge na própria linguagem.

Existe ainda a possibilidade de o leitor não perceber a diferença entre o texto pragmático e o ficcional, podendo ocorrer uma leitura pragmática, em que a ficção é tomada como uma colocação não questionada. Considerando essa possibilidade, o autor chama a atenção para os dois modos pelos quais a linguagem pode, em princípio, ser empregada: por um lado em função referencial, e por outro, em função autorreferencial. Segundo ele, o texto pragmático seria lido como uma colocação, denotativamente.

Por sua vez, o texto autorreferencial cria uma perspectiva de reverberação, já que se torna um espaço "onde a condição de uso da linguagem é determinada por meio da reflexão" (STIERLE, 2002, p. 138), criando desdobramentos no leitor, que passa a tentar preencher as lacunas presente no texto. Neste processo de tradução, ocorre o que ele chama de atividade catalisadora, ocasionado pela necessidade do leitor de preencher os vazios que se apresentam no significante para poder constituir uma compreensão.

Ainda comentando sobre a especificidade da constituição do texto ficcional, Stierle estabelece uma relação entre conceito e forma, indicando que a ficção se constitui como tal justamente porque possui uma forma ficcional, mas é somente a partir do conceito que estes textos irão se relacionar com o horizonte de expectativa do público.

Outra característica marcante do texto ficcional segundo Stierle, é que neste não existe esgotamento de uma realidade a ser retratada, pois em lugar de uma realidade que se converterá em um reflexo, estes textos criam uma poética da ficção, que pode se relacionar com a realidade em maior ou menor grau. Se neste ponto a proposta de Stierle se distancia da visão de Lukács, quando o teórico alemão afirma que o objeto da ficção nada tem a ver com a descrição minuciosa do estado de fato, ele se aproxima da ideia do filósofo húngaro, que principalmente em Narrar ou descrever? critica as obras que se isolam em processos de descrição pura, já que "a descrição não proporciona, pois, a verdadeira poesia das coisas, limitando-se a transformar os homens em seres estáticos" (Lukács, 1965, p.75).

São diversas e importantes as contribuições deste trabalho de Stierle para a Estética da Recepção. Seja complementando, ou até se opondo aos pensamentos de outros teóricos, como Jauss e Iser, o autor propõe perspectivas que até então não haviam sido estudadas. Teorizando a partir de um paradigma, o autor pensa em toda a história da literatura. E um elemento central que permeia todos os pontos levantados, é o que ele chama de figura de relevância, conceito que será discutido no próximo capítulo. 
2. O IMPORTANTE É TER IDEIAS 


\subsection{Marcel Duchamp como "figura de relevância"}

Segundo Stierle, uma das especificidades do texto ficcional seria a necessidade que estes apresentam de uma figura de relevância, mas o que significa esta figura? Por que a forma da ficção exige seu cumprimento? Qual a sua função dentro do texto? Stierle não chega a definir em seu texto o que significa esta figura, por isso agora buscamos desenvolver este conceito e analisá-lo a partir das obras de Enrique Vila-Matas.

Entendemos o conceito de figura de relevância como elemento que concentra características importantes para a sintetização e transmissão das ideias centrais de um texto. Como figura que traspassa toda a obra, levantando discussões e propondo reflexões para o leitor. Ela é forte motivadora para produção de uma obra ficcional, onde atua como tema principal. No caso das obras do autor espanhol, esta figura pode aparecer como uma ideia de arte. Em Aire de Dylan e Historia abreviada de la literatura portátil, romances nos quais a dimensão duchampiana é ainda mais acentuada, é a figura de Marcel Duchamp esse elemento imprescindível no momento de se construir uma ideia de arte.

Não é raro encontrarmos o nome do artista francês figurando entre os diversos artistas que Vila-Matas costuma ficcionalizar em suas obras, geralmente motivando os eventos principais. Citemos alguns exemplos: Em Historia abreviada, Duchamp aparece como um dos mais importantes membros da conspiração Shandy, sociedade secreta formada por artistas das vanguardas europeias da década de 1920.

Para construir esta ficção, Vila-Matas utiliza fatos reais da biografia do artista e os mescla com fatos fictícios, chegando inclusive a colher momentos de entrevista reais para utilizar como falas e citações de seu personagem. Uma destas falas resume o espírito do que foi a conspiração shandy de Historia abreviada. Diz Duchamp a Cabanne:

Porque no fundo nunca trabalhei para viver. Considero que trabalhar para viver é algo levemente estúpido desde o ponto de vista econômico. Espero que chegue o dia em que se possa viver sem a obrigação de trabalhar. Graças a minha sorte pude passar através das gotas. Em um certo momento compreendi que não devia carregar a vida com muito peso, com muitas coisas a fazer, com aquilo a que se chama mulher, filhos uma casa no campo, um carro, etc. E o compreendi, felizmente, muito cedo. Isso me permitiu viver muito tempo como solteiro muito mais facilmente que se houvesse tido que enfrentar todas as dificuldades normais da vida. ${ }^{14}$

\footnotetext{
14 "Porque, en el fondo nunca he trabajado para vivir. Considero que trabajar para vivir es algo ligeramente estúpido desde el punto de vista económico. Espero que llegue un día que se pueda vivir sin tener la
} 
Como já afirmou Vila-Matas em alguns momentos, inclusive em La levedad, ida y vuelta, Conversaciones con Marcel Duchamp é há anos a sua bíblia pessoal. É também claramente uma das grandes motivações para o romance que narra a história da sociedade secreta cujos membros se consideravam máquinas solteiras.

A escolha de Duchamp, bem como as dos demais artistas que formam a confraria mentalizada pelo narrador-shandy, e os eventos narrados no romance, captam com grande maestria o espírito que vigorava na Europa do entreguerras, bem como as ideias de arte das chamadas Vanguardas históricas. Isso só é possível porque a proposta não é a de representar a realidade histórica daquele momento a partir de um reflexo.

Em Bartleby y Compañía (2000), Duchamp aparece como um dos influentes artistas do "não", que são estes que em algum momento da vida e por motivos diversos, optam por abandonar a produção artística, como o artista francês que durante um grande período se afastou da arte e dedicou-se ao xadrez. Em Aire de Dylan (2012), Duchamp é uma inspiração para os jovens Vilnius e Débora, que formam uma sociedade infraleve denominada Ar de Dylan -em homenagem ao ready-made Air de Paris- ampola de vidro que o francês levou a um amigo em Nova York como lembrança de Paris.

obligación de trabajar. Gracias a mi suerte he podido pasar a través de las gotas. En un cierto momento comprendí que no debía cargarse a la vida con demasiado peso, con demasiadas cosas por hacer, con aquello a lo que se llama una mujer, niños, una casa en el campo, un coche, etc. Y lo comprendí, felizmente, muy pronto. Eso me ha permitido vivir mucho tiempo como soltero mucho más fácilmente que si hubiera tenido que enfrentarme con todas las dificultades normales de la vida" (DUCHAMP apud CABANNE, $1967 \mathrm{p}$. 6). 


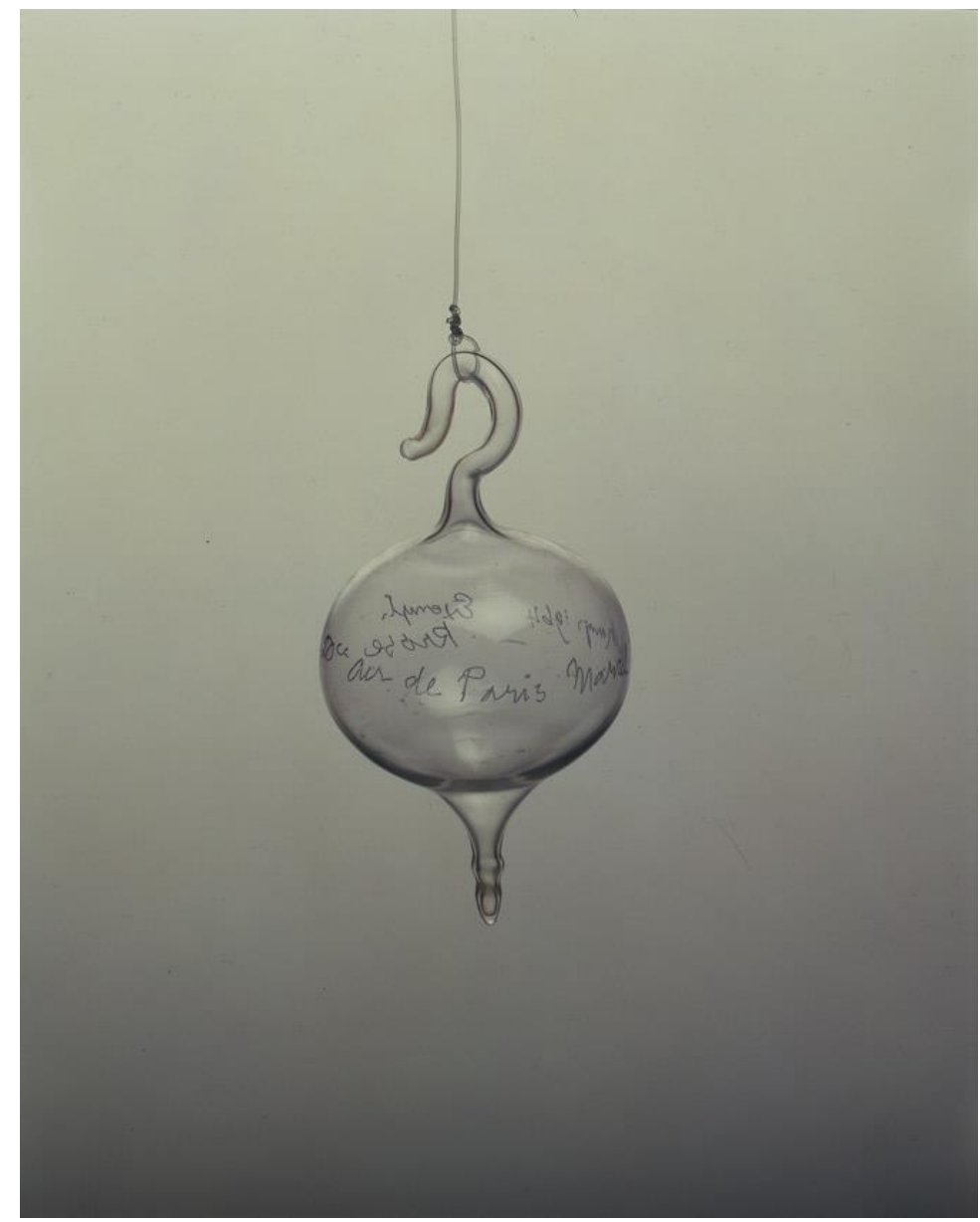

Figura 2 - DUCHAMP. Air de Paris. 1919.

Em Kassel no invita a la lógica, (2014) Vila-Matas ficcionaliza sua participação na documenta de Kassel e seu narrador autoficcional comenta sobre como o espírito duchampiano, mesmo após décadas de sua morte, ainda se faz tão presente nos museus e na arte contemporânea.

Além destes, são diversos os momentos da obra de Vila-Matas em que a figura de Duchamp aparece como portadora de características indispensáveis para a construção dessa ideia de arte. A partir da comparação entre as posturas artísticas e críticas destes dois artistas, observamos que a escolha por Duchamp não acontece por acaso.

Assim como o artista francês, o escritor espanhol defende a ruptura da arte com o cânone. Assumindo uma postura vanguardista, suas obras são mais do que ficções que tomam como tema arte e artistas que violaram modelos artísticos tradicionais; elas mesmas se apresentam como formas violadoras da norma, que rompem, por exemplo, com a ideia de gênero bem delimitado. 
Ao comentar a proximidade entre as obras de Vila-Matas e a de Duchamp, Shaj Mathew, em seu artigo intitulado Welcome to literature's Duchamp moment, fala inclusive em romance Ready-made. Ao se referir a Kassel no invita a la lógica, ele afirma:

\begin{abstract}
Assim como Marcel Duchamp perguntou se um mictório pode ser arte, o romance readymade pergunta o que a literatura pode ser, e o que deveria ser no futuro. Em vez de tentar compreender a realidade através de uma série de detalhes concretos, onisciência, múltiplos pontos de vista, ou qualquer outra coisa que nós tradicionalmente esperamos da ficção o romance readymade coloca uma ideia ou levanta uma questão [...] O romance readymade sublinha a principal virtude (ou maldição) da arte conceitual: Ao contrário do que ocorre com a arte visual tradicional [...] Se você abriu um romance ready-made você já não é apenas um espectador passivo de arte, mas um participante ativo em sua formação (MATHEW, 2015, tradução nossa).
\end{abstract}

Esta criação de obras que se abrem ao "horizonte de expectativa" do receptor é mais um aspecto em comum nas obras dos artistas em questão. Vila-Matas trabalha com esta abertura de horizontes em História abreviada de la literatura portátil. Ao propor uma arte de miniaturas, que teria como expressão máxima a Caixa-Valise de Duchamp, já que para os seus shandys "quanto mais sem vida são as coisas, mais potente e engenhosa pode ser a mente que as comtempla"15, o autor comenta sobre a importância da imaginação e da experiência do receptor para a constituição total da obra, já que é esse receptor o responsável por preencher os vazios que nela se apresentam, de forma que diante de tais obras o espectador assume um papel ativo.

Como aponta Shaj Mathew, se esta abertura de horizonte pode ser considerada como uma das maiores virtudes da arte conceitual, por outro, ela também pode se tornar objeto de críticas. O poeta e crítico brasileiro Affonso Romano de Sant' Anna (1937), por exemplo, destina críticas ferrenhas a Duchamp e à arte conceitual. Em Desconstruir Duchamp: a arte na hora da revisão (2003), livro que reúne uma série de crônicas em que comenta a situação da arte contemporânea, Sant'Anna afirma que a maioria destas obras de arte conceituais são criadas aleatoriamente, nada dizem, apenas esperam que o receptor, utilizando sua imaginação e poder de criar a partir do nada, encontre nelas um significado.

Outros críticos, por sua vez, afirmam que as obras de artistas como Duchamp apresentam, de maneira inovadora, temas de grande relevância. Octavio Paz (1914-1998),

\footnotetext{
15 "cuánto más sin vida son las cosas, más potente e ingeniosa puede ser la mente que las contempla" (VILA-MATAS, 1985, p.120).
} 
por exemplo, realiza uma análise minuciosa de $O$ grande vidro duchampiano, inclusive, Marcel Duchamp o el castillo de la Pureza (1968), dedicado a análise desta obra, teve uma reedição ampliada com o título de Apariencia desnuda (1973), em que também realiza análises de outras obras de Duchamp.

Mais tarde, em 2008, Affonso de Sant'Anna volta a publicar um livro onde critica os gestos artísticos, as obras e os defensores de Duchamp. Em O enigma vazio: impasses da arte e da crítica, o escritor brasileiro estuda a análise que vários estudiosos de arte realizaram de diversas obras duchampianas. Um de seus objetivos é confrontar diferentes interpretações de uma única obra, na tentativa de comprovar que estas interpretações são frutos antes da capacidade interpretativa e das imaginações, segundo ele, muitas vezes incabíveis, do que a do artista de criar uma obra que estabeleça um diálogo real com o público.

Este debate nos direciona novamente para os diferentes tipos de leitura dos textos ficcionais, mas também nos guia até teorias distintas, porém não distantes, da teoria da recepção. Como a da morte do autor, proposta por Roland Barthes e a narratologia, por Genette.

Em Palimpsestos (1982), Genette analisa certos aspectos da paródia. Vale lembrar que tanto Vila-Matas como Duchamp, com seu L.H.O.O.Q, por exemplo, muitas vezes têm suas obras definidas como paródias. Apesar de que, principalmente no caso de VilaMatas, quando ele toma elementos centrais de outras obras, tal como o Bartleby de Melville, ele constrói um jogo mais de autoparódia que necessariamente parodístico.

Genette chega a classificar a paródia como um gênero menor, mas em certo momento aponta para a possibilidade de ela aparecer como uma "figura de leitura". Segundo ele, "esta dimensão reduzida e esta investidura frequentemente extra ou paraliterária explicam a inclusão na retórica da paródia, considerada mais como uma figura, ornamento pontual do discurso (literário ou não), que como um gênero, ou seja, uma classe de obras"16.

Assim, quando Stierle comenta sobre a importância da segunda leitura, afirmando que esta possibilita uma percepção muito mais ampla da construção do sistema de ideias impressas no texto, evidenciando os conceitos que estão por trás do texto literário, ele

\footnotetext{
16 "esta dimensión reducida y esta investidura a menudo extra o paraliteraria explican la inclusión en la retórica de la parodia, considerada más como una figura, ornamento puntual del discurso (literario o no), que como un género, es decir, una clase de obras" (GENETTE, 1982, P. 24).
} 
estabelece uma relação da segunda leitura, como "figura de leitura", com a figura de relevância.

Ainda sobre a paródia, é preciso ressaltar que esta tem sempre um sentido de humor muito marcado, o que, claro, também acontece com as produções vilamatianas e duchampianas. Humor que geralmente vem acompanhado por um espírito transgressor. Quando se analisa estas obras sem se considerar este humor, o que se estabelece é uma interpretação mecânica, que não observa o deslocamento de significado proposto.

Porém, o fato de uma obra ser tecida com um forte sentido de humor, não impede que ela levante questões sérias e que o cumprimento de sua figura de relevância seja realizado, afinal de contas, um humor irônico sempre se mostrou como meio bastante eficaz de tocar o leitor e fazê-lo, no mínimo, refletir sobre as questões levantadas.

Sobre a figura de relevância e sua relação com a experiência Stierle afirma:

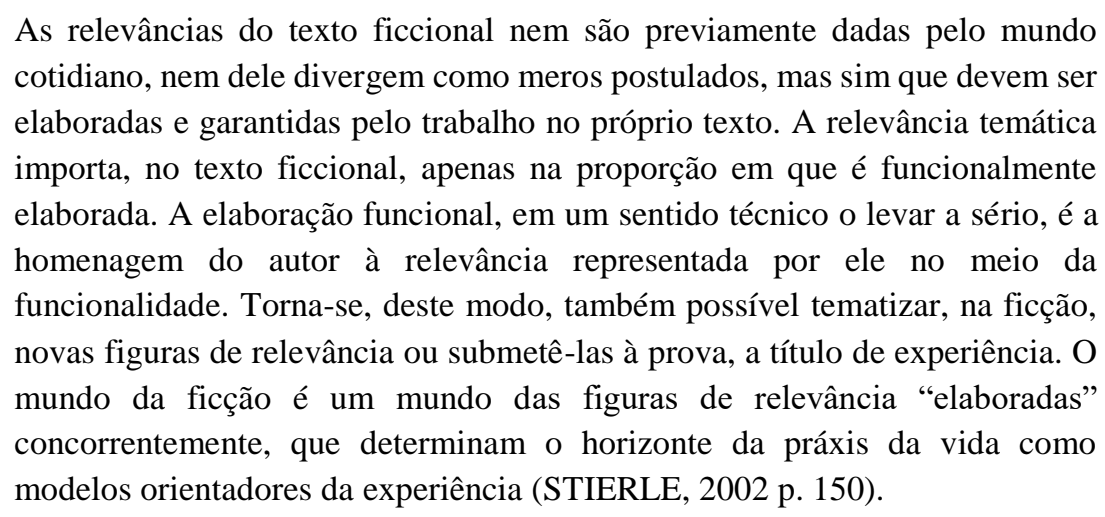

Assim, a figura de relevância se torna responsável pela mediação entre os aspectos mais verossímeis e os mais fantasiosos do texto, de modo que influencia na maneira como o leitor interage com a obra. No caso de diversas obras de Vila-Matas, é a figura de Marcel Duchamp o elemento que articula os diversos níveis textuais do "horizonte de expectativas" das narrativas. Também é por meio desta figura que o autor comprova como literatura e demais linguagens artísticas se conectam e juntas podem captar mais amplamente o "espírito" de determinados momentos históricos. 


\subsection{O elo entre tema e horizonte}

Durante todo o seu estudo em que busca estabelecer uma teoria formal da ficção, Stierle toma vários préstimos de teorias linguísticas. Ele comenta que a base da recepção se constitui por uma sequência de "significantes" e da ideia de que estes só se qualificam realmente como significantes a partir do momento em que passam a pertencer a um significado. Assim, um passo elementar da recepção é a tradução do significante em seu significado. Porém, como se sabe, para um único significante podem haver diversos significados, de modo que esta tradução consiste em encontrar o significado visado, o que implicaria uma redução.

Ao pensar nesta teoria aplicando-a em um plano mais complexo, uma obra literária, por exemplo, ocorre uma reunião de significantes e seus significados, de maneira que para se chegar na redução da quantidade de significados é necessário analisar a contextualização e o modo como significantes e significados se conectam com outros, passando a integrar uma esfera maior. A partir desta redução, é possível chegar ao núcleo do significado visado e este é definido por Stierle como estado de fato.

Porém, não é somente a atividade redutora que constitui o estado de fato. Existe também o que Stierle chama de atividade catalizadora, a capacidade do leitor de preencher vazios. Ele afirma:

O preenchimento dos vazios torna-se especialmente necessários onde o estado de fato constituído pelo texto é complexo, articulado por uma sequência de estados de fatos. Neste processo, a posição do estado de fato simples, com vista ao complexo, deve ser sempre reajustado pelo leitor (STIERLE, 1979, p.124).

A partir do momento em que o estado de fato simples torna-se complexo, a simples tradução de significante em significado passa a ser insuficiente, bem como as atividades redutoras e catalisadoras e a contextualização. O texto passa então a exigir uma nova competência recepcional que visa a relação entre tema e horizonte. Stierle chama a atenção para o fato de que na ficção, ao contrário do que acontece na experiência vivencial, esta relação é pré-constituída de acordo com os princípios estabelecidos por uma poética. $\mathrm{O}$ autor ainda diz:

No "mundo da vida" (lebenswelt), o tema para o qual se dirige a atenção, está situado diante de um horizonte do outro contingente, que necessita, em primeiro lugar, ser excluído, de forma que o distanciamento - pelo qual o tema 
se faz tema- depende de uma produção sempre renovada do agente. Ao invés, no mundo ficcional, a relação entre tema e horizonte se encontra fixada pela entrada do leitor na situação de comunicação ficcional. Isso significa que na ficção se tematiza a própria relação do tema com o horizonte (STIERLE, 1979, p. 146/ 147).

Aqui, temos a principal distinção entre textos pragmáticos e textos ficcionais. Enquanto o texto pragmático leva sempre o leitor para fora do texto, a ficção o convida para sua interioridade, já que seu núcleo é o texto em si, sua própria ficcionalidade, de modo que a linguagem e a dimensão que ela cria se torna mais relevante que uma realidade externa a ser retratada.

Refletindo sobre o caso específico da recepção dos textos de Enrique Vila-Matas, é importante considerar que em diversos deles, como em História abreviada e Aire de Dylan, o narrador já traz muitas informações sobre o universo próprio do livro, já informa ao leitor sobre sua história, sua origem, as motivações pelas quais foram escritos. Desta forma, estes textos autorreferenciais, mesmo que os textos referenciais ficcionais também convidem o leitor para sua interioridade, acabam exigindo ainda mais sua participação.

Boa parte dos textos vilamatianos, inclusive ensaios e textos jornalísticos, possuem esta poética de que fala Stierle. São textos em que se torna praticamente impossível determinar o que é real e o que é ficcional. Sobre este entrelaçamento entre elementos ficcionais e não ficcionais Stierle afirma:

\footnotetext{
A marca básica do texto ficcional é, não obstante, todas as referências à realidade, o seu caráter de colocação (setzung). Sob este pressuposto, a relação do texto com a realidade não é mais uma simples função de uma realidade a ser retratada, mas sim de uma poética da ficção, que pode ser ora mais, ora menos relacionado com a realidade e com a experiência coletiva da realidade (STIERLE, 1979, p.131).
}

Assim, voltamos à questão das figuras de experiência que se relacionam, por um lado, à intimidade de uma concepção prévia do mundo, e por outro pela estranheza. Pensando no universo vilamatiano não é raro encontrar ali uma infinidade de elementos possíveis de criar essa relação de intimidade.

Em suas obras encontram-se comentários de obras reais, de artistas conhecidos, que circulam por lugares concretos. Muitos fatos neles narrados poderiam ser comprovados em jornais, livros de história ou manuais de arte. Por outro lado, em meio a tantos elementos que causam uma sensação de intimidade no leitor, há outras tantas que provocam sensação de estranheza. 
É a figura de relevância a responsável pela mediação entre estes dois campos. Considerando, então, a figura de Marcel Duchamp como a figura de relevância de romances como Historia abreviada e Aire de Dylan, comprova-se que nela se concentram tanto os elementos que proporcionam intimidade quanto os que causam estranheza. Em Historia abreviada, por exemplo, o conhecido nome de Duchamp se converte no nome do principal membro da conspiração Shandy, também formada por artistas contemporâneos do francês.

Assim, o leitor inteirado dos movimentos artísticos da década de 1920 não estranha ao se deparar com a amizade e com a troca de opiniões artísticas entre Duchamp e Picabia, por exemplo. Desta forma, por mais que o leitor saiba que aquela sociedade secreta não tenha existido de fato e que a maioria dos fatos narrados sejam ficcionais, o texto cria uma verossimilhança.

Mesmo os acontecimentos mais fantásticos, como quando em Aire de Dylan o jovem Vilnius passa a ser assombrado hamletianamente pelo fantasma de seu pai, ou quando em Historia abreviada os odradeks, misteriosos inquilinos que habitavam o interior de cada Shandy, às vezes até adquirindo forma física, passavam a aterrorizar o Shandy que era seu duplo, estão conectados com os elementos verossímeis do texto.

Ainda em Historia abreviada, o narrador começa a se questionar se Duchamp não seria seu odradek, seu duplo, esse inquilino negro que lhe causa inquietação e exerce influência inclusive em sua produção artística. Deste modo, a figura de Duchamp é mais uma vez a mediadora entre os elementos que causam estranheza, neste caso os odradeks e os elementos que trazem intimidade, além de direcionar a atenção do leitor para a própria constituição do texto.

A figura de relevância, que em Historia abreviada e em Aire de Dylan consideramos como a figura de Duchamp, atua como elemento da ficção na qual se mesclam elementos que causam intimidade e estranhamento, abrindo portas para que se estabeleça um elo do tema da obra com todos os seus horizontes possíveis. 


\subsection{Um voo panorâmico pela obra de Enrique Vila-Matas}

Enrique Vila-Matas é hoje um dos grandes nomes da literatura espanhola contemporânea. $\mathrm{O}$ autor que sempre buscou se distanciar do estilo de narrativa comum à literatura de seu país, é ainda hoje visto como um escritor exótico e destoante do panorama literário espanhol. Aqui, empreenderemos um voo panorâmico pela obra do autor catalão, dando ênfase não apenas a seu percurso literário, mas também às leituras que críticos e escritores realizam de sua obra.

A empreendida de Vila-Matas no mundo do mercado editorial começa em 1973 quando, aos 25 anos, durante o período em que cumpria serviço militar, o autor escreve Mujer en el espejo contemplando el paisaje. Já neste pequeno romance de pouco mais de 70 páginas, é possível perceber a proximidade do texto com certos jogos borgeanos, como o manuseio com ideias de espelhos e labirintos, além da fusão entre ficção e realidade, inclusive por meio da inserção de nomes de artistas reais que ali aparecem ficcionalizados.

Em Paris no se acaba nunca (2003), o espanhol omite sua existência afirmando que seu primeiro livro foi La asesina ilustrada. Somente muitos anos mais tarde, VilaMatas deixa de ignorar a existência deste texto e o publica novamente na coletânea $E n$ um lugar solitário (2011). Esta coletânea reúne todas suas narrativas de 1973 a 1984 e conta com um prólogo em que comenta sobre sua visão de quando já era um escritor um pouco mais experiente cuja primeira obra lhe causava vergonha a ponto de proibir que esta fosse republicada. No entanto, quem escreve o prólogo é o Vila-Matas ainda mais maduro, que já desfruta de uma consciência literária que nem o jovem de 25 , nem o autor já experiente de meia idade possuíam. Nesta fase, o autor ainda reconhece os problemas de sua escrita primaveril, mas também já reconhece que esta etapa também foi indispensável na construção do escritor que ele se tornaria.

Após o cumprimento do serviço militar, Vila-Matas foi viver em Paris, onde a vida cultural experimentava um momento consideravelmente mais fecundo do que a Espanha franquista. Durante sua permanência na França, o espanhol chegou a alugar um apartamento de Marguerite Duras (1914 - 1996), a quem pediu conselhos para tornar-se um escritor e que lhe respondeu com diversas sugestões. Foi durante este período, precisamente no apartamento alugado pela escritora francesa, que Vila-Matas escreveu La asesina ilustrada, publicada em 1977. 
Este é um livro assassino, como afirma o próprio escritor em sua Breve autobiografia literária, também presente em El viento ligero em Parma: "se trata de um pequeno livro que pretende assassinar a todos que o leem"17. Deste modo, enquanto se discutia a teoria de Barthes sobre a morte do autor, Vila-Matas escrevia um livro cujo tema central era a morte do leitor. Aqui, se observa certas características que se tornariam constantes na produção vilamatiana. Como a reunião de citações, a literatura no centro das discussões e a fusão entre vida e literatura.

Posteriormente, em 1980, o autor publica Al sur de los párpados, este já escrito em Barcelona. Aqui, conta-se a história de um jovem escritor que está aprendendo a ser realmente um escritor. Vila-Matas conta que não gosta deste livro e que proíbe como pode que as pessoas o leiam; afirma que é um livro pedante, mas que, apesar de tudo, foi importante para seu próprio aprendizado, já que aprendia exatamente o que seu narrador aprendia.

Em 1982, é publicado Nunca voy al cine, livro que reúne alguns contos breves, nos quais o autor empreende quase uma autoanalise, uma busca pelos temas que lhe interessavam e que lhe parecia importante abordar em suas produções. Da mesma forma como seus romances, seus contos desta fase também já unem vida e literatura de maneira indissolúvel.

Dois anos depois, em 1984, é publicado Impostura, livro baseado em fatos reais. A ideia surgiu da história de um italiano desmemoriado que foi preso e posteriormente mandado a um manicômio, onde permaneceu por alguns meses até que publicaram sua foto em um jornal esperando que alguém o reconhecera. Após a publicação do anúncio e a desconfiança de muitos de que se tratara do professor e escritor conservador Giulio Canella, a esposa do professor o reconheceu como tal.

Pouco tempo após deixar o manicômio e tentar retomar a vida de Giulio Canella, outra mulher afirma que aquele é Mario Martino Bruneri, um tipógrafo e seu marido, o que mais tarde foi comprovado pela polícia. Porém após esta comprovação, o amnésico já vivia no Brasil ao lado da esposa de Giulio Canella. Aqui, ele dá continuidade ao trabalho do professor, de forma que ainda que fossem dois homens distintos, passam a possuir apenas uma biografia literária.

Segundo o próprio Vila-Matas, o que ele faz é adaptar esta história atordoante, porém real, e associá-la à Barcelona do pós-guerra onde, de acordo com o autor,

\footnotetext{
17 "Se trata de un librito que pretende asesinar a todo aquel que lo lee" (VILA-MATAS, 2008, p. 207).
} 
prevalecia uma sensação de impostura generalizada na qual ninguém podia acreditar totalmente nas outras pessoas e no que elas diziam ser. Neste livro, além da crítica contra seus compatriotas e do comentário sobre a situação política de Barcelona e da Espanha, o estilo irônico do escritor já aparece mais acentuado. Já aparece também a discussão sobre memória e identidade, que sempre estiveram muito presentes na produção vilamatiana.

Mas é em 1985 que Vila-Matas publica um dos livros que se tornaria um divisor de águas na sua carreira: Historia abreviada de la literatura portátil. A publicação deste romance, que se insere na chamada fase "metaficional" do autor, conta a trajetória da conspiração Shandy, nome que faz referência tanto a um tipo de cerveja como a Tristram Shandy, personagem do célebre romance de Laurence Sterne (1713 - 1768), A vida e as opiniões do cavalheiro Tristram Shandy (1759/1769).

Nesta obra, marcada por um estilo de construção híbrida, onde as fronteiras de gênero são ultrapassadas, de maneira que características ensaísticas, romanescas e historiográficas passam a ocupar o mesmo espaço no texto, o narrador nos conta os eventos vivenciados pelos artistas shandys. Com a utilização de recortes sobre as biografias vezes reais, vezes inventadas, de diversos artistas que formaram as vanguardas da década de 20, o autor capta e recontextualiza o espírito deste momento efervescente do entreguerras que marcou a história da Europa e a própria história da arte. É com o lançamento deste romance abreviado que o autor passa a ser mais conhecido tanto em seu país como internacionalmente.

É também após a publicação de Historia abreviada de la literatura portátil que começam aparecer mais análises críticas de sua obra, o que inclui não apenas este novo romance, mas também os primeiros romances deste escritor que cada vez mais vão chamando atenção da crítica.

De todas as críticas que já recebeu ao longo de sua carreira, uma em especial incomodou desmedidamente o autor, tanto que ele a menciona em diversos momentos. Trata-se de uma resenha de Historia abreviada publicada no El País, na qual se diz "se nota que el autor veranea em Cadaqués". Esta e outras diversas críticas apontavam o romance como light, bem destoante do estilo de narrativa que seus conterrâneos escreviam e liam naquele momento. Em La levedad, ida y vuelta, texto de conferência realizada na Biblioteca Nacional de Madrid em 2012, Vila-Matas ainda lembrava e rebatia as opiniões destes críticos dizendo: 
Quando Historia abreviada de la literatura portátil foi publicada, em 1985, foi um livro visto pelos críticos espanhóis mais prestigiados do momento como uma obra light em meio a explosão eufórica e "plana narratividade" em que, em oposição ao "intricado experimentalismo da década anterior", começava a acontecer na Espanha por aqueles dias. Quero deixar claro que o qualificativo light foi utilizado de forma depreciativa e que, no entanto, a maioria das novelas espanholas publicadas naquele ano já não são lembradas por ninguém, enquanto Historia abreviada - grande dinossauro em miniatura - segue aí, como paradigma da leveza (não do light), da leveza as que se ocuparia três anos depois, em 1988, Italo Calvino em seu livro Seis propostas para o próximo milênio, seis conferências escritas por 1984 e 1985 com destino à Universidade de Harvard nos Estados Unidos. A primeira delas se intitulava precisamente Lightness, Leveza. ${ }^{18}$

O autor comenta que foi apenas em 1988, quando o livro de Calvino chegou à Espanha, que alguns críticos, como boa parte do público, passaram a aceitar melhor as propostas daquele livro feliz que defendia a leveza na literatura. Nesta ocasião, muitos escritores espanhóis começaram a supor que a ideia para História abreviada havia nascido justamente da leitura do livro de Calvino, o que Vila-Matas desmente, já que o romance havia sido publicado em 1985, mesmo ano em que Calvino escrevia suas propostas para o novo milênio.

Apesar de muitas vezes rebater as críticas recebidas, Vila-Matas acredita que o fato de muitos criticarem negativamente os trabalhos de um jovem escritor é um bom sinal, indica que há escritores que têm coragem de romper com velhos mecanismos, negando-se a continuar reproduzindo fórmulas de sucesso que agradam crítica e público facilmente. Por isso, diz não se queixar da forma como Historia abreviada foi inicialmente recebida na Espanha.

Porém, enquanto dentro das fronteiras espanholas se via mais defeitos do que qualidades na obra daquele jovem escritor espanhol, na América Latina sua obra começava a ser cada vez mais valorizada, especialmente no México, primeiro lugar onde seu livro foi bem lido e criticado. Em entrevista a Gabriel Ruiz Ortega, quando

\footnotetext{
18 “Cuando Historia abreviada de la literatura portátil se publicó en 1985 fue un libro visto por los críticos españoles más prestigiosos del momento como una obra light en medio de la explosión de eufórica y "llana narratividad" que, en oposición al "intrincado experimentalismo de la década anterior", empezaba a darse en España por aquellos días. Quiero precisar que el calificativo light fue utilizado despectivamente y que, sin embargo, la mayoría de las novelas españolas publicadas aquel año ya no las recuerda nadie, mientras que Historia abreviada -gran dinosaurio en miniatura- sigue ahí, como paradigma de la levedad (que no de lo light), de la levedad de la que se ocuparía tres años después, en 1988, Italo Calvino en su libro Seis propuestas para el próximo milenio, seis conferencias escritas por 1984 y 1985 con destino a la Universidad de Harvard en Estados Unidos. La primera de ellas llevaba por título precisamente Lightness, Levedad" (VILA-MATAS, 2012).
} 
questionado porque acreditava que sua obra havia sido mais bem recebida no México do que em seu país, Vila-Matas comenta que, para ele, isso também é um mistério e chegou a perguntá-lo para o escritor mexicano e seu amigo Sérgio Pitol (1933). Este lhe respondeu afirmando que um dos motivos era o fato do México ser um país excêntrico, como era também a sua obra. O México era um país que, do mesmo modo que o catalão, também já estaria cansado da realista e pouco imaginativa literatura espanhola.

Quando, em 2001, Vila-Matas recebeu o prêmio Rómulo Gallegos por El viaje vertical, Pitol comentou em seu artigo Vila-Matas, premiado, a satisfação de ver a evolução da literatura daquele escritor que na juventude havia empreendido complicados experimentos literários a este que agora escreve perfeitas e grandes obras. Pitol comenta:

Enrique Vila-Matas foi reconhecido como um escritor de importância antes no México que em seu país. Sua excentricidade se condicionava facilmente como nosso ambiente nacional. A partir da Historia abreviada de la literatura portátil, sua obra acompanhada por um círculo cada vez mais amplo de leitores cultos: Augusto Monterroso, Bárbara Jacobs, Álvaro Mutis, Vicente Rojo, Alejandro Rossi, Margo Glantz, Juan Villoro. Dois críticos registraram sua originalidade desde o início: Christopher Domínguez Michael y Álvaro Enrigue. Na Espanha, os primeiros e quase únicos por muito tempo foram dois críticos esplêndidos: Juan Antonio Masoliver e Mercedes Monmany. Hoje seus leitores em nosso idioma formam tumultos. ${ }^{19}$

Os nomes mencionados por Pitol são poucos se comparado à quantidade de críticos e escritores que analisaram e comentaram obras de Vila-Matas. Hoje já existe uma série de textos, teses e livros destinados ao estudo da produção vilamatiana, além de coletâneas que reúnem textos de vários grandes nomes da literatura e crítica literária que comentam obras do autor catalão.

Após a publicação de Historia abreviada, é publicado, em 1986, Una casa para siempre, romance que narra a história de um ventríloquo que perde a capacidade de controlar sua própria voz. Diante da impossibilidade de continuar realizando seu antigo ofício, o ventríloquo e narrador decide começar a escrever suas memórias. Aqui, também já é possível encontrar temas que sempre estiveram presentes na produção vilamatiana,

\footnotetext{
19 “Enrique Vila-Matas fue reconocido como un escritor de importancia en México antes que en su país. Su rareza se acondicionaba fácilmente con nuestro entorno nacional. A partir de la Historia abreviada de la literatura portátil, su obra fue seguida por un círculo cada vez más amplio de lectores ilustrados: Augusto Monterroso, Bárbara Jacobs, Álvaro Mutis, Vicente Rojo, Alejandro Rossi, Margo Glantz, Juan Villoro. Dos críticos registraron su originalidad desde el inicio: Christopher Domínguez Michael y Álvaro Enrigue. En España, los primeros y casi únicos por mucho tiempo fueron dos críticos espléndidos: Juan Antonio Masoliver y Mercedes Monmany. Hoy día sus lectores en nuestro idioma forman tumultos” (PITOL, 2001).
} 
como a questão da construção de um discurso próprio a partir da utilização de vozes alheias, além da criação de um narrador que encontra uma possibilidade de criar uma vida a partir da escritura.

Vila-Matas afirma que é durante a escrita deste livro que ele começa a se preocupar constantemente com a estrutura demandada pela construção de um romance. Mais uma vez sua obra foi muito mal recebida pela crítica espanhola. Por outro lado, na França, apenas dois livros espanhóis foram considerados como alguns dos melhores livros traduzidos ao francês, entre eles Una casa para siempre. Ele conta que foi neste momento que deixou de se considerar um escritor espanhol e passou a aplicar a si mesmo a lei do estrangeirismo, afirmando que, a partir dali, não pertencia mais a nenhum país e ao mesmo tempo pertenceria a todos.

Em 1991, é publicado Suicidios ejemplares, livro que reúne contos que gira em torno do tema do suicídio. Como o autor mesmo conta, é precedente de Bartleby y compañía, já que também narra a história de pessoas que tomam a iniciativa de abandonar sua atividade, porém, neste caso, de uma forma muito mais abrupta e definitiva. Muitas vezes o suicídio não significa necessariamente a morte física, mas pode referir-se a diferentes formas de morte, inclusive a que se dá apenas dentro do espaço da literatura.

Aqui, como também ocorre em Historia abreviada quando aborda o tema do suicídio, a gravidade do tema não deixa de ser tratada com certo humor. Nestes contos, ao falar destas pessoas que convivem com a ideia do suicídio, muitas vezes rendendo-se a ela, Vila-Matas aborda diversas questões e até mesmo cria personagens que fazem o possível para parecer estrangeiros dentro de seu próprio país. São textos que também revelam a sensação de não pertencimento do autor a seu país.

No ano seguinte, em 1992, é lançado El viajero más lento, seu primeiro livro de ensaios, carregados sempre por uma boa dose de ficção. O livro também conta com a presença de nomes de grandes artistas, como o ator Marlon Brando e o espanhol Salvador Dalí, em situações que mesclam circunstâncias e citações reais dos artistas com as situações imaginadas por Vila-Matas.

Hijos sin hijos é lançado em 1993. Trata-se de uma reunião de contos que retoma temas tratados em obras anteriores, como suicídios em Suicidios ejemplares e as máquinas solteiras de Historia abreviada. Os filhos sem filhos são personagens sem raízes que não possuem nenhuma pretensão de terem herdeiros ou laços muito estreitos com ninguém, já que para conseguirem continuar a existir verdadeiramente só poderiam 
alimentar-se de si mesmos. O livro conta mais uma vez com citações de nomes que frequentemente são mencionados pelo Espanhol como Kafka e Fernando Pessoa.

Em 1995 é publicado El traje de los domingos, uma coleção de ensaios e artigos jornalísticos no qual Vila-Matas incorpora e comenta sobre a vida de um escritor que se dedica a ser crítico literário, prologuista de amigos e ainda colunista dominical. Nestes textos, bem como nos romances do autor, o narrador se aproxima muito da vida de VilaMatas, mas nunca se pode confiar totalmente que a voz por trás destes ensaios é pura e simplesmente a do autor catalão.

No mesmo ano é lançado Lejos de Verzcruz, livro que homenageia o país que primeiro soube reconhecer o valor de sua excêntrica literatura. Este livro, no qual mais uma vez autor e narrador se confundem, se conta a história de um professor espanhol que viaja ao México após a morte de seu irmão lhe causar diversos transtornos, inclusive a sensação de que ouvia vozes e de que os hóspedes de sua livraria, quase como odradeks, o observam de maneira hostil. Durante a viagem, o perturbado narrador se encontra com Sérgio Pitol, que lhe ajuda a lidar com sua complicada situação.

O livro está repleto de acontecimentos bastante imaginativos que fazem lembrar situações realmente vivenciadas pelo autor, como suas diversas visitas ao México e à cidade de Veracruz, onde costumava encontrar Sérgio Pitol. O livro é mais um em que se evidencia a visão de Vila-Matas de que vida e ficção podem se tornar uma só. Além disso, homenageia e faz referências a diversos autores que compõe a rica literatura mexicana.

O livro seguinte é Extraña forma de vida (1997), que conta a história de um escritor que divide a sua vida em duas atividades: escrever e espionar pessoas desconhecidas nas ruas de Barcelona. Vila-Matas cria um jogo ao criar um narrador realista que todo o tempo espiona pessoas e tenta retratar de forma mais real possível aquilo que observa, mas que a final só comprova que por mais realista que uma obra literária se proponha a ser, ela nunca será espelho da vida real, sendo que o fato de ser realista causa o efeito contrário e acaba por distanciar mais a literatura da realidade.

É em 1999 que se publica El viaje vertical, livro pelo qual o autor receberia o Prêmio Romulo Gallegos. O livro narra a história de Federico Mayol, um barcelonês nacionalista que parece a síntese de todos os aspectos de seus conterrâneos que incomodam a Vila-Matas. É um senhor de 77 anos que sempre foi "pesado" e intolerante, mas que após ser deixado por sua esposa e desprezado por seus filhos, é obrigado a se mover, deixando tanto os espaços que costumava a habitar quanto as regras e ideologias 
que seguiu durante tantos anos. Em sua Breve autobiografia literária o autor confessa que muito de Federico Mayol foi baseado em seu pai, um nacionalista catalão.

Em 2000 é publicada uma das mais importantes obras do autor: Bartleby $y$ compañía. Este texto, inexistente, segundo próprio narrador que se auto intitula como CasiWatt, é constituído por notas de pé de páginas trabalhadas em forma de diário. Nesta obra o narrador, assim como a maioria dos narradores vilamatianos, apresenta uma série de características comuns a Vila-Matas, desde o fato de estarem escrevendo de Barcelona até o de vivenciarem os mesmos acontecimentos vividos pelo autor barcelonês.

O livro leva este título por conta do personagem do romance Bartleby, o escrivão (1853) de Herman Melville (1819 - 18991), que diante da possibilidade de produção artística optou pelo "não". Nestas notas de roda pé de um texto inexistente, são mencionados diversos artistas, como Marcel Duchamp, Arthur Rimbaud (1854 -1891), entre outros, que após produzirem uma ou mais obras e até adquirirem certa fama, decidem abandonar a produção artística. Neste livro, o autor já demonstra seu interesse em propor um debate sobre os caminhos e idiossincrasias da literatura contemporânea.

Entre 2002 e 2005 o autor publica respectivamente El mal de Montano e Doctor Pasavento, livros que também abordam as chamadas "patologias da escritura", já que enquanto a síndrome de Bartleby causa no artista enfermo a impossibilidade de produção, o mal de Montano causa uma compulsividade pela escritura, e a "patologia" sugerida em Doctor Pasavento relaciona-se com a desaparição do narrador diante da mesma.

Em meio a esta trilogia das patologias da escritura, o autor ainda publicou París no se acaba nunca (2003), mais uma obra fortemente marcada por um caráter autoficcional, que neste caso tende mais para um divertido autorretrato em que VilaMatas empreende uma divertida reflexão sobre seus anos de "aprendiz de escritor" na Paris da década de 1970. Aqui, o narrador relembra e comenta com bastante ironia os anos de sua juventude, quando, em Paris, no mesmo período em que vivia no apartamento alugado por Marguerite Duras, ele se encontrava cada vez mais certo de que o que dava sentido a sua vida era a literatura. Também em sua Breve autobiografia literária o autor diz o seguinte sobre este livro:

Na realidade, uma tentativa de dar a meus leitores alguma notícia verdadeira sobre mim. Mas tudo isso disfarçado baixo a ideia de que o livro é um fragmento do romance da minha vida em que tudo é verdade porque tudo é 
inventando, pois no final das contas, um relato autobiográfico é uma ficção entre muitas possíveis. ${ }^{20}$

Este é um dos fragmentos nos quais se evidencia que a vida de Vila-Matas está totalmente conectada a literatura e que para ele não há como desvincular a realidade da ficção, a verdade da imaginação.

Em 2004, é publicado no México mais um livro que reúne artigos e ensaios: $E l$ viento ligero en Parma. Nesta coletânea encontram-se diversos textos que revelam as opiniões de Vila-Matas sobre arte e literatura. Nestes textos, bem como em todos os artigos publicados pelo autor, é possível observar que mesmo quando se trata de comentários críticos, o autor não abre mão de uma poética ao escrevê-los. Todos eles evidenciam a forte relação que o autor estabelece entre literatura e vida, de modo que ambas passam a se indissociáveis. Desta forma, tais textos surgem como comentários de produções literárias, suas ou de outro autor, mas se tornam também mais um espaço em que Vila-Matas utiliza sua linguagem, fruto do diálogo com diversos autores de diversos lugares, mas uma linguagem própria, para aproximar crítica à vida e à literatura.

Em 2008, é publicado mais uma obra que marca uma transição na obra do autor. Dietario voluble marca a passagem do Vila-Matas metaficcional para um mais autobiográfico, que já ocupa lugar de destaque entre os grandes nomes da literatura contemporânea e que transmite esta experiência em suas obras. Este é mais um livro escrito como diário, neste caso, diário de leitura, que abarca notas de leitura do escritor que se mesclam com suas memórias pessoais. Também nesta obra se levantam questões referentes à contemporaneidade. A partir deste momento, as opiniões e ideias do autor sobre literatura e arte se tornam cada vez mais evidentes.

Em 2012 é lançado Aire de Dylan, livro que surge, segundo o próprio autor, de sua vontade de se divertir. O romance estabelece um diálogo com Historia abreviada e também narra o surgimento de uma sociedade secreta. Conecta-se também a Bartleby y compañía. Estes três livros formam, de acordo com Vila-Matas em Levedad: ida y vuelta, "uma linha no ramo nobre -ou no mínimo extremamente shandy- da árvore da vida da minha obra" ${ }^{21}$. São livros que se manifestam em favor da ligeireza na literatura.

\footnotetext{
20 "En realidad, un intento de darles a mis lectores alguna noticia verdadera sobre mí. Pero todo esto disfrazado bajo la idea de que el libro es un fragmento de la novela de mi vida en el que todo es verdad porque todo está inventado, pues a fin de cuentas un relato autobiográfico es una ficción entre muchas posibles" (VILA-MATAS, 2004, p.2012).

21 "Una línea en la rama noble -o como mínimo extremadamente shandy- del árbol de la vida de mi obra" (VILA-MATAS, 2012).
} 
O livro seguinte é Kassel no invita a la lógica, publicado em 2014. O livro narra a experiência de Vila-Matas na Documenta 13 na cidade alemã em 2012. Nesta ocasião o autor foi convidado a participar como escritor residente e durante a exposição iria a um restaurante chinês onde escreveria na frente dos expectadores que a qualquer momento poderiam the interromper. Ele comenta também sobre as impressões que as obras de outros artistas participantes da Documenta lhe causaram e as reflexões sobre a arte contemporânea que esta experiência lhe possibilitou.

Ao contrário do que aconteceu com suas primeiras publicações, Kassel no invita a la lógica, até então o último romance publicado por Vila-Matas, foi muito bem criticado tanto dentro quanto fora da Espanha. A cada dia, o autor ganha mais olhares sobre suas obras, tanto de leitores comuns como de importantes nomes da literatura mundial, que fazem questão de escrever sobre o espanhol que é hoje um dos mais expressivos nomes da literatura de seu país. 


\subsection{A dimensão duchampiana na obra de Vila-Matas}

Enrique Vila-Matas foi um jovem que desde cedo defendeu sua liberdade criativa. Em 1971, quando a Espanha ainda vivia baixo à ditadura franquista, o barcelonês deixou sua cidade natal e foi prestar serviço militar na África, onde escreveu seu primeiro livro, Mujer em el espejo contemplando el paisaje (1973). Pouco tempo após seu regresso a Barcelona, ao encontrar a cidade sob domínio dos repressores, ele decide se mudar para Paris, onde os artistas, bem como toda população, gozavam de maior autonomia e liberdade. Foi ali que o autor escreveu seu segundo livro, La asesina ilustrada (1977), o qual anos mais tarde, em seu livro Paris no se acaba nunca (2003), consideraria seu primeiro.

O fato de suas primeiras obras terem sido escritas fora da Espanha já indica o desejo do autor de "viajar, perder países" como propõe o título do poema de Fernando Pessoa, mais um destes autores com quem Vila-Matas compartilha ideias de literatura e que também é figura constante em seus textos. Perder países significaria primeiro se distanciar da literatura produzida na Espanha naquele momento, uma literatura grave, bem distante da literatura leve tão defendida em História abreviada de la literatura portátil. Significava se distanciar do regime franquista e todas as perdas que este causou à cultura espanhola.

Assim, Vila-Matas sempre se identificou mais, segundo suas próprias palavras, com autores mais extravagantes do que com seus compatriotas que continuavam a se dedicar a adormecida narrativa espanhola daquele momento. Segundo o autor, escritores como o mexicano Sérgio Pitol e o polonês Witold Gombrowicz, vistos no panorama espanhol como estranhos e inusitados, também o influenciaram na construção de seu estilo de narrativa livre e inabitual.

Como homem ávido por cultura que sempre foi, o escritor desde cedo se interessou por toda forma de manifestação artística, de modo que as ideias que tinha após o contato com as obras dos mais variados artistas logo eram apresentadas em seus textos. Estes artistas e suas obras aparecem constantemente nos romances, nos ensaios, nos textos jornalísticos do autor, sendo que uma destas presenças constantes e mais relevantes é a de Marcel Duchamp. Por isso, aqui investigamos a dimensão que o artista francês ocupa na obra do autor. 
Um dos principais motivos para Vila-Matas admirar Duchamp é evidente: o francês com certeza é um destes artistas excêntricos que, não estando satisfeito com o que acontecia no mundo das artes, fez questão de remar contra a corrente ao produzir sua obra. Esta, além de ser totalmente diferente de qualquer coisa que já havia sido produzida até então, era um manifesto contra certas imposições que limitavam fortemente a ideia do que poderia ser considerado uma obra de arte, ao mesmo tempo em que também revelava sua despreocupação em fazer parte desse suntuoso mundo artístico.

Este artista insolente, que também perdeu países e se negou a produzir uma obra "normal”, a qual um público acostumado com certos estilos contemplaria e aceitaria facilmente, não demorou a se tornar uma das maiores inspirações para aquele desassossegado jovem espanhol, que anos mais tarde, em seu Dietario voluble (2008) revelaria:

Quando via Marcel Duchamp jogando xadrez no Café Melitón de Cadaqués,
não sabia que aquele homem havia se retirado da pintura e transformando sua
vida em uma obra de arte. Eu tinha dezessete anos e só via um francês que
jogava xadrez todos os dias. Foi alguns anos depois que me inteirei que estava
vendo um homem sabiamente liberado de todas as estúpidas ataduras da arte.
Não nego que faz tempo me tenta a ideia de me situar no rastro duchampiano. ${ }^{22}$

Em Paris no se acaba nunca, o autor também confessa que de todos os seus mitos artísticos de juventude, Duchamp era o único que ele continuava a admirar. As obras, as ideias, a postura do francês, são tão decisivas na produção de Vila-Matas que influenciaram não somente o que o autor seria, mas também aquilo que nunca viria a ser: “juego a no ser Duchamp y serlo", é o que diz em Una vida absolutamente maravillosa, mais um de seus artigos publicados no El País.

É claro que o dono dessa vida absolutamente maravilhosa a que se refere é Duchamp. Essa vida leve, despreocupada, é o estilo de vida que motivará os membros da sua sociedade secreta Shandy em Historia abreviada e da sociedade infraleve de Aire de

\footnotetext{
22 "Cuando veía a Marcel Duchamp jugando al ajedrez en el Café Melitón de Cadaqués, no sabía que aquel hombre se había retirado de la pintura y había convertido su vida en una obra de arte. Yo entonces tenía diecisiete años y sólo veía a un francés que jugaba todos los días al ajedrez. Fue unos años después cuando me enteré de que había estado viendo a un hombre sabiamente liberado de todas las ataduras estúpidas del arte. No niego que hace tiempo que me tienta la idea de situarme en la estela duchampiana" (VILAMATAS, 2008, p.12).
} 
Dylan. É também motivação para que, em meio a toda produção literária que considerava exageradamente grave e pesada de seu país, o autor construísse sua narrativa ligeira.

É importante ressaltar que essa leveza nada tem a ver com amenidade ou com mero entretenimento. Ao contrário, é uma narrativa que comprova que assuntos complexos podem ser narrados com humor e leveza, de modo bastante literário, em que a parte artística não perde em relevância para a abordagem de temas externos.

Uma das características em comum entre estes dois artistas é o gosto confesso pela contradição. Uma das diversas contradições que pode se comentar sobre a produção vilamatiana é que, mesmo os assuntos mais pesados e intensos, como a questão do suicídio que perpassa muitas de suas obras, é tratado de maneira aprazível e com um forte sentido de humor. Como Vila-Matas mesmo afirma no artigo em que comenta sobre a maravilhosa vida que Duchamp soube levar, tanto a parte na qual o autor se aproxima do artista francês, quanto na parte em que se diferenciavam, servem como inspiração para o espanhol compor muitas de suas obras.

O principal motivo para Duchamp lograr o êxito de uma vida bem vivida ele mesmo revela a Pierre Cabanne em Conversaciones con Duchamp: levar a vida sem demasiado peso, sem preocupação com muitas coisas para fazer. Assim, a escolha do artista de simplesmente parar de produzir não lhe causou nenhum peso de consciência ou mal-estar. O fato de não ter novas ideias não o inquietava ou o obrigava a se repetir, pelo contrário, deixar de produzir e poder se dedicar tranquilamente a hobbies, como jogar xadrez, que era mais um dos prazeres daquela vida maravilhosa, poderia ser muito tranquilizante.

Essa abdicação à produção é uma das diferenças entre Duchamp e Vila-Matas. A pesar da possibilidade desse abandono ser frequentemente abordados nos textos do espanhol, desde o início de sua carreira como escritor, ele se dedicou arduamente não apenas a seus romances e ensaios, mas também a seu blog e artigos. Em um destes, Escribir es dejar de escribir, ele diz: "escrever vale a pena, não conheço nada mais atrativo que escrever, ainda que seja necessário pagar um certo tributo por esse prazer". Assim, se Duchamp encontrou sua satisfação também ao renunciar a produzir, Vila-Matas a encontra justamente na prática de seu ofício.

Em La casa de la escritura. Conversación con Enrique Vila-Matas, um dos textos presentes no livro organizado por Margarita Heredia, Vila-Matas portátil: un escritor ante la crítica (2007), que reúne uma série de textos de diversos críticos que comentam a 
obra do autor, ele revela a Rodrigo Fresán que nesse lado prolífico se assemelha mais a Picasso:

\begin{abstract}
Eu acredito que na mina personalidade convivem três temperamentos artísticos. Um é o de Picasso, a personalidade do trabalhador infatigável, do homem-máquina de escrever que fui durante esses últimos dez anos. Mas tenho também o lado Dalí: essa compulsão delirante e exibicionista de chamar a atenção sobre mim, sobre meu personagem; uma atitude que com o tempo justifiquei como necessidade de chamar atenção sobre mim para ver se finalmente me liam. E a terceira faceta, que é a mais secreta, e que é a que no fundo adoro: a vertente Duchamp, que é a indiferença em relação à arte. ${ }^{23}$
\end{abstract}

Porém mesmo que sua personalidade, bem como sua obra, seja um tecido composto por um pouco de tudo o que leu ao longo da vida, na mesma entrevista o autor salienta: "não acredito que esse equilíbrio triangular vá se manter para sempre na minha vida. Evidentemente acabará triunfando Duchamp acima de todos e de tudo" ${ }^{24}$.

Este aspecto no qual os artistas divergem também está bastante presente nas obras de Vila-Matas, principalmente em Bartleby y compañía, afinal, existe uma atitude que indique mais o diagnóstico de síndrome de Bartleby que decidir parar de produzir e passar a dedicar maior parte do tempo a jogar xadrez?

Este livro se constrói a partir de contradições. É escrito por um narrador que afirma categoricamente que deixou de escrever, já que também sofre com a síndrome de Bartleby, e que decidiu catalogar outros artistas que assim como ele optaram por abandonar seus ofícios, reunindo-os em notas de pé de página de um texto inexistente.

Neste livro que existe sem que exista um texto, Duchamp aparece como alguém que conhecia muito bem a sombra de Bartleby, tanto que chegou a fabricá-la manualmente. Esta sombra produzida pelo francês é bem mais literal do que se espera, trata-se da sombra produzida por um toldo no qual após ficar sem ideias, o artista passou a se dedicar a reformá-lo durante anos a fim de que fornecesse uma sombra maior e mais confortável para seu descanso.

\footnotetext{
23 "Yo creo que en mi personalidad conviven tres temperamentos artísticos. Uno es el de Picasso, la personalidad del trabajador infatigable, del hombre-máquina de escribir que he sido durante estos últimos diez años. Pero tengo también el lado Dalí: esa compulsión delirante y exhibicionista de llamar la atención sobre mí, sobre mi personaje; una actitud que con el tiempo he justificado como necesidad de llamar la atención sobre mí para ver si de una puta vez me leían. Y esta la tercera faceta, que es la más secreta, y que es la que en el fondo adoro: la vertiente Duchamp, que es de la indiferencia hacia el arte" (VILA-MATAS, 2007, p.321).
}

24 “No creo que ese equilibrio triangular vaya a mantenerse para siempre en mi vida. Evidentemente acabará triunfando Duchamp por encima de todos y de todo" (VILA-MATAS, 2007, p.321). 
Observa-se, assim, que o nome do artista francês é presença constante nos textos de Vila-Matas, seja em romances, em artigos e até mesmo em muitas de suas entrevistas. Se em alguns destes textos, como Bartleby y compañía, esta figura de Duchamp se conecta com os fatos narrados e passa a ser um elemento que contribui amplamente com esta, em outros casos Duchamp se torna o centro da narrativa, do qual se irradiam os demais temas. É o caso dos romances trabalhados aqui, Historia abreviada de la literatura portátil e Aire de Dylan.

Em La levedad, ida y vuelta, Vila-Matas faz uma análise de sua própria obra e afirma que ela se divide em três partes. A primeira delas, na qual se insere Historia abreviada, seria uma indagação sobre o sem sentido, a segunda, o momento em que o autor se dedicou a construir, segundo suas próprias palavras, sua automitografia e a terceira, na qual se inclui Aire de Dylan, uma busca de se aproximar da verdade por meio da ficção.

Nestas três fases, por mais que seu estilo de narrativa tenha passado por diversas mudanças, muitos aspectos sempre estiveram presentes. Seus narradores sempre tiveram muito em comum com o autor, as citações literárias sempre foram presença confirmada, o mundo das artes, em seus mais diversos aspectos, sempre ocupou o centro de suas discussões e as ideias de Marcel Duchamp, mesmo quando não mencionadas diretamente, sempre dialogaram com as do autor e perpassaram suas obras.

Em Historia abreviada de la literatura portátil Duchamp aparece como o principal membro da conspiração Shandy, sua Boîte-en-valise se torna o anagrama dessa sociedade e seu estilo de vida de máquina solteira que leva a vida sem demasiadas preocupações, sempre de viagem, passa a ser o estilo de vida que um membro daquela sociedade deveria levar. Vila-Matas define este romance como um livro feliz. Nele, o autor toma um tema que sempre lhe chamou a atenção: sociedades secretas, e cria ele mesmo sua sociedade formada por artistas que admirava. 


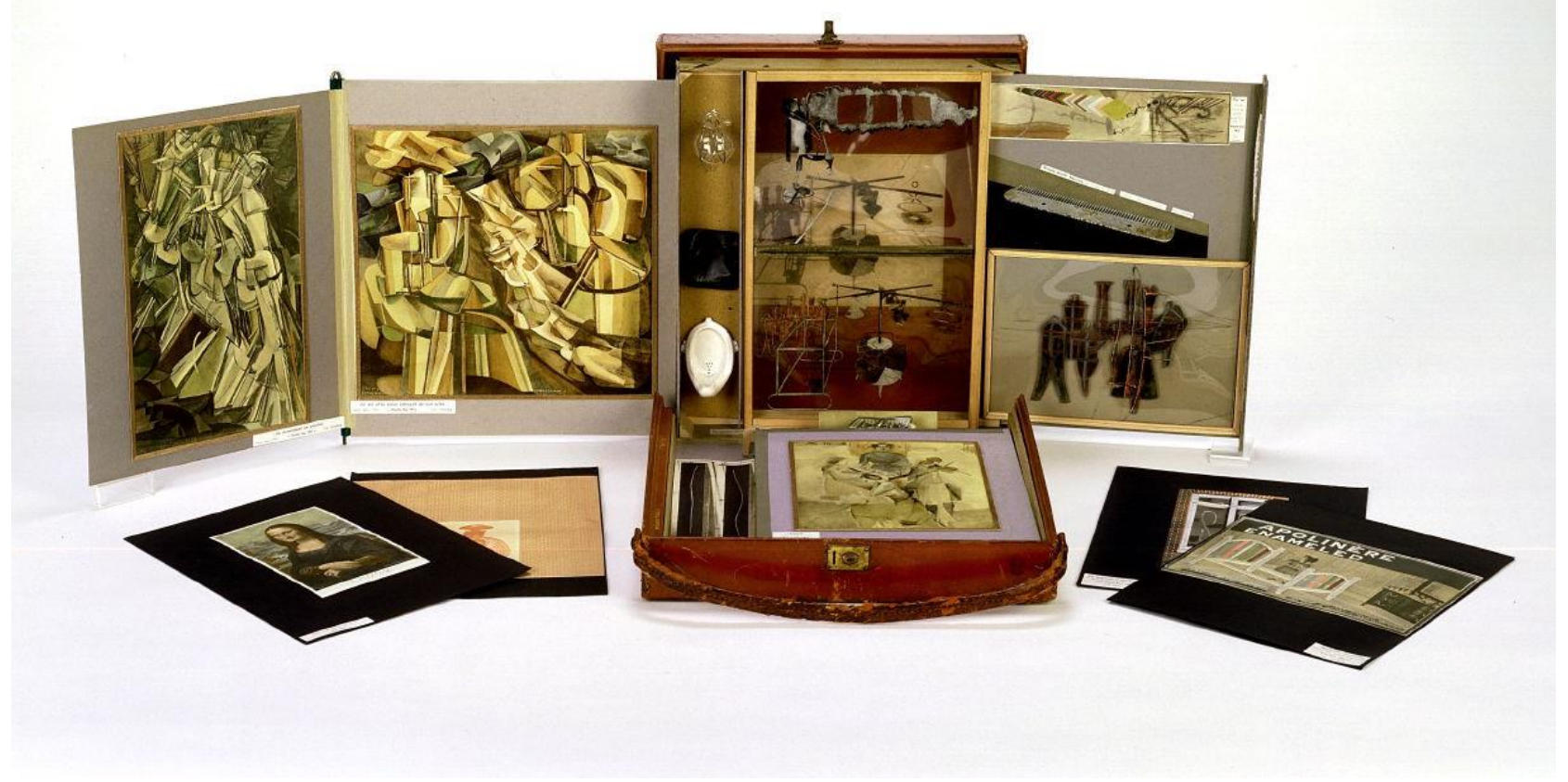

Figura 3 - DUCHAMP. Boîte-en-valise. 1941.

A Bô̂te-em-valise, mais do que guardar miniaturas de produções duchampianas, guarda o mistério típico das coisas pequenas. Mas guarda principalmente o espírito portátil. O espírito de quem está pronto para seguir viagem a qualquer momento, deixando para trás os velhos costumes, a fim de explorar e construir novos caminhos possíveis. $\mathrm{O}$ espírito de quem está pronto para ganhar todas as coisas que a estrada tem a oferecer e para abandonar outras tantas, entre elas a própria pátria, como indica Fernando Pessoa em seu poema, também presente em Poesias (1942):

\section{VIAJAR! PERDER PAÍSES!}

Viajar! Perder países!

Ser outro constantemente,

Por a alma não ter raízes

De viver de ver somente!

Não pertencer nem a mim!

Ir em frente, ir a seguir

A ausência de ter um fim,

E a ânsia de o conseguir! 
Viajar assim é viagem.

Mas faço-o sem ter de meu

Mais que o sonho da passagem.

O resto é só terra e céu.

(PESSOA, 1942 [15ª ed. 1995], p. 182)

A vida de uma pessoa que abre mão de viver em um único lugar e se põe a viajar, seja de forma literal, literária ou de ambas, é também a vida de uma pessoa que renuncia uma identidade única em favor de múltiplas identidades. Essa escolha é um dos fatores que une Vila-Matas a Pessoa, Duchamp, Dylan e tantos outros artistas cosmopolitas e multíplices. Em El discurso de Caracas, discurso de recebimento do XII Prémio Internacional de Novela Rómulo Gallego (2001) por El viaje vertical, mais tarde reunido na coletânea de artigos literários El viento ligero en Parma, o autor menciona o poema de Pessoa e comenta sobre seu desejo de ser sempre um estrangeiro:

É bom viajar, como é bom — como dizia Pessoa— viajar e perder países, perdê-los todos, perder seu próprio país, perder até sua identidade ou no mínimo, ironizar sobre o desejo maníaco de identidade, se tornar menos neurótico e aceitar o fato de que a vida é sempre uma mestiçagem [...] É necessário caminhar até uma literatura que conforme com o espírito do tempo, uma literatura mista, mestiça, onde os limites se confundam e a realidade possa dançar na fronteira com o fictício, e o ritmo apague essa fronteira [...] Eu quero ser estrangeiro sempre. De um tempo para cá, acredito que cada vez mais a literatura transcende as fronteiras nacionais para fazer revelações profundas sobre a universalidade da natureza humana. ${ }^{25}$

O espírito do também viajante Duchamp é outro que se conecta com o do escritor que desde cedo se propôs encarar a estrada. Mesmo antes de começar a escrever, VilaMatas já ansiava por transcender as fronteiras de seu país, não só a geográfica, mas

25 "Es bueno viajar, que es bueno — como decía Pessoa — viajar y perder países, perderlos todos, perder tu propio país, perder hasta tu identidad o como mínimo, ironizar sobre el deseo maniático de identidad, volverse menos neurótico y aceptar el hecho de que la vida es siempre un mestizaje [...] Hay que ir hacia una literatura acorde con el espíritu del tiempo, una literatura mixta, mestiza, donde los límites se confundan y la realidad pueda bailar en la frontera con lo ficticio, y el ritmo borre esa frontera [...] yo quiero ser extranjero siempre. De un tiempo a esta parte, creo que cada vez más la literatura trasciende las fronteras nacionales para hacer revelaciones profundas sobre la universalidad de la naturaleza humana (VILAMATAS, 2008, p. $200-201)$. 
principalmente a ideológica. E o fez de diversas maneiras. Habitou, explorou, visitou muitos países, mas foi a literatura que o levou a lugares mais distantes. Foi outro constantemente, e assim conectou-se consigo mesmo. Começou diversos textos sem destino, sem ter um fim, e acabou encontrando vários. Ao escrever Historia abreviada, encontrou um meio de viajar junto a um de seus grandes inspiradores, Marcel Duchamp.

Vinte e sete anos depois de publicar Historia abreviada, Vila-Matas publica Aire de Dylan, mais um livro que conta a história de uma sociedade secreta, mas dessa vez Duchamp deixa a posição de membro e passa a ocupar a de homenageado, afinal esta nova sociedade formada inicialmente apenas pelos jovens Vilnius e Débora, é denominada Ar de Dylan e considerada como infraleve em homenagem ao francês e ao seu Aire de Paris. Novamente esta influência não se limita às obras de Duchamp, mas também chega à postura destes jovens ante a vida e a arte.

Aire de Dylan também surge da influência de Duchamp na produção, porque não na vida, de Vila-Matas. Suas maiores motivações para escrever esse livro em que resgata os temas e a feliz escritura do jovem autor de Historia abreviada também vêm do artista francês. A primeira destas motivações é que este livro surge do desejo de Vila-Matas de se divertir, o prazer que encontra ao escrever fica ainda mais evidente quando comenta estes dois livros. Em La levedad, ida y vuelta ele diz: "com Aire de Dylan tratei, sobre tudo, de me divertir. <<Quis me divertir >>, recordo que dizia frequentemente Duchamp quando lhe perguntavam por aspectos de sua obra" ${ }^{26}$. De Duchamp também veio a vontade e ideia de voltar aos temas tratados em sua juventude:

Enquanto escrevia o romance, como Marcel Duchamp na idade madura, quando sem ideias que superassem as que já havia tido em sua vida, decidiu se aprofundar nas mais antigas e juvenis, convencido de que estas poderiam chegar a lhe revelar, em uma hipotética nova fase de sua obra, com maior profundidade e complexidade. ${ }^{27}$

Outros dois elementos que também se encontram na origem do livro é o direito de um artista de se contradizer e o de se retirar do que quiser, quando quiser, inclusive se

\footnotetext{
26 “con Aire de Dylan he tratado, sobre todo, de divertirme. <<Quise divertirme>>, recuerdo que decía a menudo Duchamp cuando le preguntaban por aspectos de su obra" (VILA-MATAS, 2012).

27 "Mientras escribía la novela, como Marcel Duchamp en la edad madura, cuando falto de ideas que superaran a las que ya había tenido en su vida, decidió profundizar en las más tempranas y juveniles, convencido de que éstas podrían llegar a revelársele, en una hipotética nueva etapa de su obra, con mayor calado y complejidad" (VILA-MATAS, 2012).
} 
retirar da obrigação de produzir. Nestes aspectos Aire de Dylan estabelece forte ligação com Bartleby y Compañía. Seu narrador se contradiz ao escrever o romance após ter afirmado que jamais voltaria a escrever e ao fazê-lo também nos conta a história de dois jovens que defendiam o direito de se retirar do meio artístico, como o fez Duchamp e os diversos escritores mencionados em Bartleby y compañía.

Essa divisão em três etapas que o próprio Vila-Matas faz de sua obra comprova que Duchamp e suas ideias sempre se fizeram presentes nela. Tudo o que está entre Historia abreviada e Aire de Dylan, e o que vem depois, também está repleto de ideias duchampianas.

Em seu último romance, Kassel no invita a la lógica (2014), o narrador, que mais uma vez se emaranha a Vila-Matas, conta sua experiência como escritor convidado na Documenta 13, em Kassel. Nesta ocasião, o autor participou de uma performance na qual todos os dias ele ia a um restaurante chinês e escrevia diante dos espectadores.

Durante o período de realização desta grande exposição de arte contemporânea, Vila-Matas teve contato com diversas obras e artistas que, assim como Duchamp, e também graças ao legado que este deixou às artes, expunham suas obras provocadoras e repletas de novas propostas artísticas. O contanto com estas obras suscitou não apenas uma série de reflexões sobre a arte contemporânea, mas também as memórias do jovem Vila-Matas, que antes mesmo de conhecer profundamente os artistas e a arte vanguardista, já via em Duchamp uma de suas fontes de inspiração.

O narrador nos conta sobre o dia em que, sendo ele muito jovem, viu em um restaurante as viúvas de Man Ray e Duchamp e comenta:

\footnotetext{
Não sabia que tipo de obra haviam deixado seus maridos, mas havia visto antes nas paredes do restaurante fotos das enigmáticas pegadas culturais de um e outro e desejava ser um criador estrangeiro como eles, desejava ter um ar distinto que intuía que estes artistas sempre haviam exibido e, se não fosse pedir muito, quando terminasse o verão, não ter que voltar jamais à <<atrasada〉> Barcelona; desejava ser um artista de vanguarda, ou seja, o que naquele momento eu entendia como <<alguém em ruptura com a encolhida realidade artística da minha cidade $>>$. E, como desejava tudo isso, pensava que o modo mais direto de me tornar um <<vanguardista >> seria adotar um ar parecido ao que adotavam Marcel Duchamp ou Man Ray. ${ }^{28}$
}

\footnotetext{
28 "No sabía que clase de obra habían dejado sus maridos, pero había visto antes en las paredes del restaurante fotos de las enigmáticas huellas culturales de uno y otro y deseaba ser un creador extranjero como ellos, deseaba tener el aire distinto que intuía que estos artistas siempre habían exhibido y, si no era mucho pedir, cuando terminara el verano, no tener que volver jamás a la «retrasada» Barcelona; deseaba ser un artista de vanguardia, es decir, lo que entonces yo entendía por «alguien en ruptura con la encogida realidad artística de mi ciudad». Y, como deseaba todo esto, pensaba que el modo más directo de
} 
Este fragmento também revela um pouco da dimensão duchampiana na produção de Vila-Matas. Vemos que desde quando era um jovem descontente com a realidade cultural de seu país, o espanhol viu nos artistas vanguardistas, e de modo especial em Duchamp, uma inspiração para criar uma obra que rejeitasse qualquer possibilidade de ser um espelho mimético da realidade, que busca a inovação, se recusando fazer parte e dar continuidade a um sistema já saturado. O que interessa não é reproduzir, mas reinventar.

Aqui, o narrador revive as memórias do jovem que logo se tornaria escritor e que em Historia abreviada criaria uma sociedade secreta formada somente por estes artistas que como Duchamp sabiam cultivar a arte da insolência, livro que, por sua vez, daria origem a Aire de Dylan, que agora tinha Duchamp não como membro, mas como influencia e homenageado. Toda a produção vilamatiana entre os vinte e sete anos que separam os romances também revelam a herança que esta inspiração juvenil deixou ao autor.

convertirme en «vanguardista» sería adoptar un aire parecido al que adoptaban Marcel Duchamp o Man Ray” (VILA-MATAS, 2014 p. 169). 
3. A ARTE DA CONTRADIÇÃO 


\subsection{Breve história de uma sociedade infraleve}

A Ninguém é dado abarcar num único instante a plenitude de seu passado. Nem a Shakespeare, que eu saiba, nem a mim, que fui seu herdeiro parcial, foi oferecido esse dom. A memória do homem não é uma soma; é uma desordem de possibilidades indefinidas.

Jorge Luis Borges

Uma única vida na qual muitas vidas habitaram. Uma pessoa que soube ser várias pessoas diferentes, mas que mesmo ao abrigar múltiplas personalidades, também soube ser único. Trata-se de Robert Allen Zimmerman, ou Bob Dylan. Dylan é considerado por muitos um dos mais influentes artistas do século XX, e é também uma incógnita para aqueles que tentam categorizá-lo.

Não é por acaso que Vila-Matas elege a figura do cantor americano como uma das figuras centrais de Aire de Dylan. Neste romance o cantor aparece não como um personagem, mas como um artista que também representa o espírito de sua época, espírito que consegue captar não apenas em suas canções, mas também por suas atitudes e inúmeras facetas que assumiu ao longo de sua carreira.

Mais uma vez, trata-se de um artista que, apesar da distância geográfica e da linguagem artística com a qual trabalha, guarda diversas semelhanças com Vila-Matas. Bem como Dylan, o espanhol fez da multiplicidade mais do que tema que permeia muitas de suas obras, mas uma das mais fortes características de sua carreira como escritor.

Esta multiplicidade é substancial em Aire de Dylan, romance no qual Vila-Matas reflete sobre sua própria trajetória. Nele, o autor tem a oportunidade de unir vozes não só com outros artistas e escritores, como geralmente o faz, mas com ele mesmo, com todas as suas versões. Aqui, o experiente autor tem a oportunidade tanto de avaliar suas antigas opiniões de jovem escritor quanto de refletir sobre quem ele se tornou.

A viagem tem início quando o narrador, um prolífico escritor barcelonês cujo nome não é mencionado, recebe uma carta com o convite para participar de uma conferência sobre o fracasso e literatura em San Gallen. Apesar do tema incomum, esta poderia ser apenas mais uma conferência entre as várias que o narrador-escritor já havia participado ao longo de sua vida, não fosse pela presença do jovem cineasta Vilnius 
Lancastre, filho de outro proeminente nome da literatura espanhola, o escritor Juan Lancastre.

A própria presença de Vilnius na conferência já era vista por ele como um fracasso em si, visto que quem realmente havia sido convidado era seu pai que falecera poucos dias antes. Assim, o jovem cineasta cuja filmografia era composta por um único curtametragem e que trabalhava em um projeto que buscava reunir um grande arquivo geral sobre o fracasso - que talvez um dia poderia até ser convertido em um filme - substituiu seu pai na conferência com o texto que nomeou como Teatro de realidad.

Vilnius lê o seu Teatro de realidad, narrado em forma de conto, com a intenção secreta de fracassar e, deste modo, poder mais uma vez incorporar fatos de sua própria vida em seu grande arquivo de histórias sobre o fracasso. Seu objetivo era que ao final da leitura daquele longo texto, todos já tivessem se enfadado com os seus relatos que narravam os quase inacreditáveis acontecimentos que sucederam a morte de seu pai.

Em seu teatro de realidade, o jovem revela que, após um escorregão em seu quarto, ele começa a ter memórias de momentos que nunca havia vivido de fato, percebendo então que só poderiam ser memórias da juventude de seu pai. Mais do que estas memórias, Vilnius sente que o próprio Juan Lancastre havia se infiltrado em sua mente e o chamava desde um mundo desconhecido. Chamava-o por Vilnius, mas também por Hamlet.

Impressionava a Vilnius a capacidade da vida de se assemelhar à ficção e até mesmo de ultrapassá-la em criatividade e na ocorrência de eventos aparentemente impossíveis. Ainda assombrado diante daquela situação, o rapaz se questiona quais eram os objetivos de seu pai ao se infiltrar em sua mente e o porquê da sua voz interior insistir em chamá-lo por Hamlet.

Durante a leitura de cada página de seu texto, Vilnius olhava esperançoso para o auditório esperando que este se esvaziasse aos poucos, até o ponto de que já não restasse ninguém para ouvi-lo. Gradativamente, ele percebia que estava cada vez mais perto de alcançar seus objetivos. Porém, novamente Vilnius fracassou em fracassar. Ao final da leitura de seu Teatro de realidad, restava outro barcelonês que ouviu atentamente do primeiro ao último minuto aquela conferência, sendo o único a aplaudi-la no final.

Este ouvinte fiel, que sem saber frustrou as expectativas de Vilnius, é o narrador de Aire de Dylan, um escritor da mesma geração de Juan Lancastre, com quem já tivera oportunidade de se encontrar algumas vezes. Este narrador, por motivos que nem ele conhecia muito bem, estava ansioso por uma oportunidade de conversar pessoalmente com Vilnius. Havia algo naquele jovem extremamente parecido com Bob Dylan em seus 
anos de juventude que despertava seu interesse, além da curiosidade em saber mais sobre toda aquela história de infiltração paterna.

Na manhã seguinte, os dois se encontraram durante o café da manhã no hotel em que estavam hospedados. Apesar do narrador afirmar que seu interesse em conversar com o jovem não era questionar sobre o que de realidade e o que de ficção havia em seu relato, - posto que esta era uma pergunta que sempre o faziam e não lhe agradava nada - ele admite que gostaria de saber se de fato Juan Lancastre havia infiltrado em sua mente e se as interferências paternas ainda se realizavam mesmo sem a permissão de Vilnius, que lhe respondeu positivamente.

Após o fim do congresso e o retorno a Barcelona, o teatro sem teatro - modo como o escritor se referia à conferência de Vilnius - ainda o deixava inquieto e provocava reflexões. Em seu texto, Vilnius ainda contava como a relação com seu pai e sua mãe Laura Verás, mulher cuja maldade histriônica causava horror e humor, era conturbada. Fala também do seu desejo de descobrir o verdadeiro autor da frase "cuando oscurece todos necesitamos a alguién" que ouviu pela primeira vez no filme Três camaradas, roteirizado também por Scott Fitzgerald. Logo, esta frase passa a ser chamada de frase motor, pois a busca por seu verdadeiro autor leva Vilnius a lugares e descobertas impensáveis.

A frase o leva a procurar por Claudio Arístides Maxwell, um grande conhecedor do cinema hollywoodiano da década de 70, que lhe afirma que Fitzgerald foi apenas um dos oito roteiristas de Três camaradas. Vilnius decide então ir a Hollywood por acreditar que lá poderia descobrir a autoria daquela frase tão importante em sua vida, frase que sentia que se conectava com toda a sua história e poderia inclusive levá-lo a sua realidade última. Depois de alguns dias de interação com muitos cineastas que, devido a sua semelhança com o cantor americano lhe apelidaram Little Dylan, o jovem descobre que um dos roteiristas ainda era vivo. Aquela informação restaurou suas esperanças de descobrir aquilo que logo percebeu que dificilmente descobriria com os cineastas de sua geração, visto que nenhum deles sequer conhecia aquele filme.

O próximo passo de Vilnius foi ir até Culver City, onde vivia John Pechmann, um senhor de 90 anos, único roteirista ainda vivo de Três camaradas. Apesar da idade, Pechmann estava em forma e continuava a ser um bom conversador, além disso ainda se dedicava a estudar e praticar hipnose. Vilnius tentou não ser muito específico sobre as razões pelas quais buscava a autoria da frase "Cuando oscurece todos necesitamos a alguién”, mas suas tentativas foram em vão porque, apesar de sua resistência, Pechmann 
o hipnotizou. Durante o tempo que passou hipnotizado, o rapaz falou de sua vida e de sua realidade última:

Você disse que todos éramos uma mesma pessoa e uma mesma fonte de energia e que você era seu pai e sua mãe e também seu filho e todas as pessoas do mundo inteiro e seu rosto se iluminou de uma maneira que jamais havia visto quando disse estar diante da realidade última, e logo resultou que essa realidade final era o barulho da chuva sobre este telhado de ferro. ${ }^{29}$

Mesmo se sentindo humilhado por ter sido hipnotizado sem consentimento, Vilnius decide continuar a conversa a fim de descobrir algo relevante sobre uma das frases mais importantes de sua vida, e quem sabe até descobrir qual dos oito roteiristas do filme era o seu autor. Pechmann revela então que, de certa forma, havia nove roteiristas, sendo que o nono era um senhor apelidado Harlem, homem controlador que não estava satisfeito com a escolha feita por seu filho Pechmann de se tornar um cineasta.

Durante uma noite na qual os oito jovens cineastas trabalhavam no roteiro do filme, Harlem apareceu no escritório exigindo que seu filho fosse embora com ele, Fitzgerald pede ao senhor que se acalme enquanto Pechmann se recusa a voltar. Harlem que, como seu filho afirma, era um homem muito comprometido com seu papel de pai, bem como Juan Lancastre, sente-se então desconsertado. Soluçando devido ao efeito de bebida, diz a seu filho: "cuando oscurece todos necesitamos a alguién". Os roteiristas se olham e, antes mesmo de trocar qualquer palavra, concordam que aquela frase deveria entrar no roteiro de Três camaradas. Anos depois Pechmann não apresentava nenhum sentimento por aquela frase que Vilnius havia escolhido para ser seu epitáfio.

O filho de Lancastre voltou para casa convencido de que Harlem era o roteirista mais fugaz de toda a história de Hollywood, e que era aquele pai como o seu - muito comprometido com seu papel de pai - que havia desenhado a linha de sua vida e seu destino com aquelas palavras. Ao conseguir descobrir o autor da frase, a única queixa de Vilnius é que outra vez ele fracassara em seu desejo de fracassar em sua busca. Ainda assim o rapaz voltou contente para Barcelona acreditando que, com ajuda de sua "frasemotor", ele ainda poderia desvendar muitos mistérios.

Ao regressar, Vilnius e o narrador, que a essa altura já haviam se tornado amigos, se encontravam frequentemente. Em um destes encontros, o jovem convida o escritor para

\footnotetext{
29 “Dijiste que todos éramos una misma persona y una misma fuente de energía y que tú eras tu padre y tu madre y también tu hijo y todas las personas del mundo entero y se iluminó tu cara de una manera que jamás había visto iluminársela a nadie cuando dijiste estar frente a la realidad última, y luego resultó que esa realidad final era el ruido de la lluvia tibia sobre este tejado de hierro" (VILA-MATAS, 2012, P. 141).
} 
assistir mais uma conferência que aconteceria em uma livraria próxima ao bairro em que moravam. Outra conferência de Vilnius que giraria em torno de seu pai, visto que havia sido planejada pelos sócios do "club de interrupdores Lancastre", cujos membros eram grandes admiradores da extensa produção literária de Juan Lancastre. Para aquela noite, Vilnius escreveu um texto chamado Teatro de ratonera. Além de convidar seu novo colega e escritor, Vilnius convidou sua namorada a participar da execução daquele teatro de ratoeira. A jovem se chamava Débora e já havia sido amante de seu pai.

Aquele texto guardava uma série de revelações que deixariam todos os presentes, inclusive o experiente escritor, muito surpresos e cheios de incógnitas. É revelado que, assim como Lancastre, Laura Verás também tinha um amante, e este era Claudio Arístides Maxwell, o especialista em cinema hollywoodiano dos anos 70 a quem Vilnius havia pedido ajuda para tentar descobrir o autor daquela frase. Porém, uma das revelações centrais era a existência de manuscritos das memórias de Lancastre.

Tanto Vilnius como Débora desejavam ter estes manuscritos em mãos, porém Laura Verás afirma ao filho que, em uma noite na qual bebia e sofria muito pela morte do marido, acabou os atirando ao fogo. Logo o jovem descobre que, caso os manuscritos estivessem realmente destruídos, a razão não era o desconsolo e o luto de sua mãe pela morte de seu pai, mas a raiva que ela sentia por Lancastre haver dedicado suas memórias a Débora. Além disso, não era apenas Vilnius que mantinha uma relação conturbada com os pais. O casamento entre Laura e Juan passou longe de ser o começo de uma família feliz.

Devido às duas surpreendentes descobertas recentes, Vilnius começava a suspeitar que não era em vão que seu pai se infiltrara em sua mente e que havia um forte motivo para que essa voz interior o chamasse repetidamente por Hamlet. O jovem passou a suspeitar que a morte de seu pai não fora culpa de problemas cardíacos, como os laudos médicos apontavam. Na verdade, havia uma grande possibilidade de que se tratasse de um assassinato planejado por Laura e seu amante. O Teatro de ratonera era então uma tentativa de encontrar justiça pela morte de seu pai, que apesar de sempre haver discordado com todas as escolhas do filho, principalmente as artísticas, sempre foi menos perverso com ele do que Laura Verás.

O objetivo de Vilnius ao ler aquele texto, também escrito em forma de conto, não era exatamente o mesmo de Hamlet ao planejar a representação de um assassinato semelhante ao de seu pai e observar quem na plateia reagiria àquela peça como um 
culpado de assassinato. O plano do jovem era deixar as suspeitas subtendidas para todos aqueles ouvintes e contagiá-los com o remorso que ele sentia por Laura e seu amante.

Os boatos sobre a hipótese de Lancastre haver sido envenenado de forma que parecesse um ataque cardíaco foram se espalhando, fazendo com que Laura e Claudio tomassem duras atitudes contra Débora e Vilnius, atitudes tão cruéis que indicavam aos leitores que pessoas frias, como aquele casal, poderiam sim serem cruéis o suficiente para cometer um assassinato.

A atitude de Laura e Max só aumentou nos jovens a vontade de que a morte de Lancastre fosse vingada. Após tantos anos de desentendimento com o pai, Vilnius sentia que agora deveria defender sua memória. Até mesmo sua produção literária, que em diversos aspectos chegava até a irritar o jovem, a essa altura já havia sido defendida por ele.

Vilnius decide então que as memórias de Juan Lancastre devem ser publicadas de qualquer forma. Se sua mãe realmente as tivesse eliminado, elas poderiam ser escritas por outra pessoa que conhecesse as obras e fatos da vida do escritor. Porém, como tanto Vilnius quanto Débora não tinham a menor intenção de perder tempo de suas vidas com nenhuma espécie de trabalho, ainda mais com o trabalho de escritura destas memórias que demandaria tanto esforço, eles pedem ao narrador-escritor que realize este trabalho.

O narrador, apesar da decisão de não voltar a escrever nenhum livro a mais, sentese interessado na proposta. Segundo ele, esta poderia ser uma oportunidade para alterar tudo o que achava que deveria ter sido feito diferente em sua obra. As memórias de Juan Lancastre poderiam ser o encerramento perfeito de sua carreira de escritor. Além disso, esta seria uma ótima chance para que o experiente escritor continuasse em constante contato com Vilnius e Débora.

O laço que unia aquele jovem casal era forte, ambos estavam conectados por muitos aspectos:

Eram, além de jovens com leves e sempre passageiros problemas mentais, problemas que se faziam presentes tanto nele como nela, em forma de rajadas [...] Além de jovens artistas da indolência, talvez eram também ou haviam começado a ser uma espécie de sociedade incipiente. Uma sociedade artística de dois, mas que não os estranharia se abrissem caminhos e não tardassem em crescer. Recordavam vagamente a Marcel Duchamp, que ao longo de sua vida não fez muitas coisas, mas de vez em quando fez alguma. ${ }^{30}$

\footnotetext{
30 "Eran, además, jóvenes con ligeros y siempre pasajeros problemas mentales, problemas que se hacían presentes tanto en él como en ella, en forma de ráfagas [...] Aparte de jóvenes artistas de la indolencia, tal vez eran también o habían empezado a ser una especie de sociedad incipiente. Una sociedad artística de dos, pero que no les extrañaría que abriera caminos y no tardara en crecer. Recordaban vagamente a Marcel
} 
Assim, o casal se torna uma sociedade secreta que não se dedicava a nenhuma atividade concreta. $\mathrm{O}$ que lhes interessava eram as ideias, apenas uma por dia era o suficiente. Deste modo, a cada dia eles comentavam sobre suas ideias que poderiam se referir às coisas mais simples e aparentemente banais da vida cotidiana.

Como a vida, que é tudo ao mesmo tempo, era a história destes três artistas. Seus destinos eram marcados pelo inesperado e pela contradição. Ao mesmo tempo em que a trajetória do jovem casal se assemelhava a um filme feliz no qual dois jovens com estilo de vida semelhantes se encontram e vivem felizes, poderia se assemelhar também a um drama psicológico no qual os terríveis vilões cometiam grandes barbáries contra um casal que já sofria o suficiente com suas enfermidades mentais.

Além disso, a vida de Vilnius era, ao mesmo tempo, fuga e busca pelo fracasso. Enquanto decide que já não pretende mais produzir nenhuma obra, provavelmente temendo o fracasso, ele dá início a empreitadas tendo como principal objetivo o fracasso. Lhe incomodava o fato de tê-lo encontrado muitas vezes ao longo de sua vida, mas nunca quando buscava por ele.

Há ainda o narrador afirmando que já não escreveria nenhum livro, mas que conta sobre essa escolha justamente enquanto narra tudo o que sucedeu seu encontro com Vilnius naquele congresso em San Gallen. Durante esta narração comenta ainda sobre a possibilidade de escrever as memórias abreviadas de Juan Lancastre. E é este escritor, vezes tão distante, vezes tão conectado ao estilo destes jovens artistas, que viria a ser o terceiro membro desta sociedade infraleve, sociedade que:

Em homenagem a Duchamp, [...] podia se chamar Ar de Dylan, o que lhes permitiria imaginar a si próprios como uma gota de vidro que continha a essência de sua época, o ar de seu tempo, do nosso, de um tempo ligado em arte ao mundo de Bob Dylan, criador escorrediço e homem de tantos personagens e personalidades. ${ }^{31}$

Assim que decide aceitar a proposta de escrever a bibliografia de Lancastre, o escritor logo começa a ter diversas ideias. Inventa muitos eventos que deixariam estas

Duchamp, que a lo largo de su vida no hizo muchas cosas, pero de vez en cuando hizo alguna" (VILAMATAS, 2012, p. 201).

31 "En homenaje a Duchamp, [...] podía llamarse Aire de Dylan, lo que les permitiría imaginarse a sí mismos como una gota de cristal que contendría la esencia de su época, el aire de su tiempo, del nuestro, de un tiempo ligado en arte al mundo de Bob Dylan, creador escurridizo y hombre de tantos personajes y personalidades" (VILA-MATAS, 2012, p. 201). 
memórias ainda mais interessantes, também escolhe alguns acontecimentos de sua própria vida para narrá-los como se quem os tivesse vivido fosse Lancastre. Porém, ao saber das intenções de Vilnius de publicar as memórias de seu pai escritas por outro conhecido autor espanhol, Laura Verás revela que os manuscritos estavam intactos e que em breve seriam publicados.

Embora Débora continue com esperanças de que esta outra biografia ainda fosse concretizada, o narrador revela seus planos de não voltar a escrever. E agora que os manuscritos do próprio Lancastre haviam reaparecido, já não havia necessidade de adiar a sua decisão.

Poucos dias depois, os três conspiradores infraleves são pegos de surpresa com a notícia de que Claudio havia sido encontrado morto em sua casa após cometer suicídio. No entanto, esta notícia não abalou tanto como a que receberam alguns dias depois. Laura Verás, durante um almoço com uma representante da editora que publicaria as memórias de Lancastre, se engasgou e morreu ali mesmo.

Apesar de todo o ódio que cultivou ao longo da vida, Vilnius atende ao último desejo de sua mãe: que seu corpo fosse cremado e as cinzas lançadas em um rio. O jovem é acompanhado por Débora e o escritor que, enquanto observa as cinzas de Laura serem lançadas à água, tenta afugentar o medo que o destino daquela família continue seguindo o mesmo desfecho escrito por Shakespeare. Àquela altura, ele já estava muito apegado aos jovens artistas e companheiros de sociedade secreta para aceitar que o fim de suas vidas chegasse tão cedo e de forma tão drástica, como chegou para Hamlet e Ofélia.

Esta é a história que Vila-Matas nos conta em Aire de Dylan, romance que o autor afirma tratar-se de um de seus textos mais pessoais. O livro se torna uma revisão do autor sobre as diferentes etapas de sua carreira, revisão na qual, além de comentar sobre o escritor que foi, viaja ao seu interior para se conectar com seu antigo eu e também lhe dar a oportunidade de opinar sobre o escritor que viria a ser e a obra que produziria.

Bem como Bob Dylan, Vila-Matas também é homem de múltiplos personagens e personalidades. Neste romance ele, mais uma vez, constrói um narrador bastante semelhante a ele, que certamente confunde muitos leitores desavisados. Além disso, empresta algumas de suas inúmeras facetas a Vilnius e Juan Lancastre, de modo que o que vemos é a reunião de três personagens diferentes que representam um único homem: Enrique Vila-Matas. 


\subsection{Viver ou encenar: eis a questão}

Se assim como Bob Dylan, Vila-Matas é um artista que exerce entusiasmado o direito de, dentro e fora de sua obra, assumir diferentes facetas e representar múltiplos papéis, seria inevitável que um dia teatro e cinema apontassem como cerne de um de seus romances. É o que acontece em Aire de Dylan, mais uma das produções vilamatianas que evidenciam a ótica do autor segundo a qual não há muros que separem realidade e ficção.

Já na primeira linha do romance, pode-se notar a forte relação que este estabelece com o teatro, assim como toda a literatura está associada à vida. O livro se inicia com as seguintes palavras do narrador:

\footnotetext{
Algumas pessoas entram muito tarde no teatro da vida, mas quando o fazem parecem que entram sem rédea e direto no final da obra. Esse foi o meu caso. E hoje posso afirmar com toda a segurança. A representação começou na manhã em que minha mulher me entregou uma carta que acabava de chegar da Suíça, um convite a participar em um congresso literário sobre o fracasso. ${ }^{32}$
}

Assim, o narrador já confere um tom teatral ao romance ao definir os relatos que começa a narrar a partir daquele momento como representação. Naquele dia em que se iniciou mais uma história dentro da história de sua vida, dois fatos lhe surpreenderam. Primeiro, o modo como sua esposa cria uma reverência teatral para comunicá-lo que alguém o considerava um completo fracassado; depois, a natureza insólita daquele convite -afinal, mesmo que, segundo sua visão- poucas coisas estivessem tão conectadas nesta vida como literatura e fracasso, este não era um tipo de convite que escritores costumam receber.

Passada a surpresa inicial, o escritor se dá conta de que o tema daquele congresso literário era totalmente legítimo e aceita com naturalidade e até certa indiferença o fato de que seu nome figurasse entre nomes de escritores que mantinham uma proximidade com o fracasso. A questão com a qual se defrontava agora era se deveria adotar uma nova máscara e postura de fracassado ou simplesmente continuar levando sua vida normal de fracassado:

\footnotetext{
32 "Algunos entran muy tarde en el teatro de la vida, pero cuando lo hacen parece que entran sin brida y directos ya hasta el final de la obra. Ése fue mi caso. Y hoy puedo afirmarlo con toda seguridad. La representación empezó la mañana en la que mi mujer me entregó una carta que acababa de llegar de Suiza, una invitación a participar en un congreso literario sobre el fracaso" (VILA-MATAS, 2012, p.13).
} 
Li a carta suíça com a mais absoluta calma, como se soubesse desde sempre que um dia a receberia. Não movi nem um só músculo do rosto. Encarei o convite com elegância e sentido de fatalidade, como se estivesse em um canto de um grande cenário. E fiquei só com uma dúvida para as horas seguintes: pôr a máscara de fracassado ou continuar levando minha vida normal de fracassado. ${ }^{33}$

Outra vez realidade e ficção se encontram tão próximas que se torna impossível distinguir qual é qual, até porque aqui não há esta distinção. Todo o tempo, a vida dos personagens toma rumos que parecem totalmente fictícios, tanto que seguir a vida normalmente parece ser exatamente o mesmo que encenar uma peça teatral.

O narrador não é o único que se sente como se sua vida seguisse o roteiro escrito por um dramaturgo imaginativo. Vilnius, não poucas vezes, também se surpreende com os eventos inverossímeis que marcam sua vida; não é sem razão que o texto escrito por ele para aquela conferência se intitulava Teatro de realidad. Ao jovem também "lhe havia deixado perplexo observar que um fragmento de sua vida pudesse ter um ar tão parecido ao de uma história de ficção, especialmente um ar de peça teatral com desenlace inesperado e cortina abrupta" 34 .

O Teatro de realidad era uma variante do Cinema-verdade, ou Cinéma Vérité, estilo que surgiu na Europa como oposição ao cinema hollywoodiano clássico. Esta nova forma de se pensar e fazer cinema buscava realizar filmes que retratavam os personagens pautando-se mais em suas vidas reais. $\mathrm{O}$ objetivo principal não era narrar fatos e apresentar os personagens, de modo que sua principal função fosse contribuir para o desenrolar do enredo, importava mais trabalhar a realidade daquele personagem. Consequentemente, havia também uma preocupação com a retratação de seu estado psicológico e a subjetividade de seus sentimentos.

Embora narrado em forma de conto, o Teatro de realidad é um texto híbrido influenciado pela linguagem teatral e cinematográfica adotada por aquele jovem cineasta produtor de um único curta-metragem. Neste texto, Vilnius não se intimida em lançar a público suas angústias e se abrir quanto ao que se sente, até porque uma de suas aspirações

\footnotetext{
33 "Leí la carta suiza con la más absoluta flema, como si hubiera sabido desde siempre que un día la recibiría. No moví ni un solo músculo de la cara. Encajé la invitación con elegancia y sentido de la fatalidad, como si estuviera en un rincón de un gran escenario. Y me quedé sólo con una duda para las horas siguientes: ponerme la máscara de fracasado o continuar llevando mi vida normal de fracasado" (VILA-MATAS, 2012, p.14).

34 "Le había dejado perplejo observar que un fragmento de su vida pudiera tener un aire tan parecido al de una historia de ficción, un aire sobre todo a pieza teatral con desenlace inesperado y telón abrupto" (VILAMATAS, 2012, p. 17).
} 
ao participar daquele congresso era justamente gritar suas histórias para desconhecidos que provavelmente não se importariam nada com ela - como forma de desabafo.

É a partir do que ouve naquele dia que o narrador também começa a tecer uma análise psicológica de Vilnius que, se fisicamente mantinha muitas semelhanças com Bob Dylan, psicologicamente recordava em muitos aspectos o melancólico Hamlet. Afinal, Dylan e o personagem de Shakespeare também são ambíguos e apresentam diversas semelhanças entre si.

Bem como o príncipe da tragédia de Shakespeare, o rapaz que guardava memórias ressentidas de sua infância e que agora sofria os impactos da morte de seu pai, também empreendia uma busca obstinada por sua realidade última e não media esforços para desvendar os mistérios que o inquietavam.

É ao se dar conta de que todos os indícios apontavam para o fato de que a morte de Juan Lancastre não havia sido natural, mas planejada por Laura Verás (personagem que parece estar sempre atuando de forma teatral e descomedida como a grande vilã do enredo) que o jovem decide executar o plano semelhante ao de Hamlet e infundir entre seus ouvintes a ideia de que sua mãe era uma assassina. Se sua vida imitava, contra a sua vontade, os mesmos caminhos sinuosos da ficção, por que ele não poderia por conta própria imitá-la também?

Então Vilnius, em companhia de Débora, cria o Teatro de ratonera. Neste momento, Vila-Matas, a partir de seus personagens porta-vozes, fala diretamente sobre um fato que se faz perceptível em cada uma de suas obras, que a ficção é a mais eficaz forma de se expor a realidade:

Com seu teatro de ratoeira lhes guiava aos dois, a Débora e Vilnius, o convencimento de que a ficção sempre servirá muito melhor para dizer ou insinuar a verdade que outros meios que se revelaram ineficazes. E lhes guiava também outra convicção: a de que à história do gênero épico lhe vem faltando há anos um novo capítulo, talvez o último, um que seria verdadeiramente épico e que incluiria a todos aqueles narradores que lutaram com esforço titânico contra toda forma de fingimento ou de impostura e cuja luta teve sempre um evidente caráter paradoxo, pois os combatentes foram escritores que viveram mergulhados até o pescoço no mundo da ficção: artistas que buscaram o modo de dizer ou de se aproximarem da verdade através dela, através da ficção, conseguindo que ao menos dessa tensão estilística surgissem as maiores aproximações à verdade conhecidas até agora. ${ }^{35}$

35 "Con su teatro de ratonera les guiaba a los dos, a Débora y Vilnius, el convencimiento de que la ficción siempre servirá mucho mejor para decir o insinuar la verdad que otros medios que se han revelado ineficaces. Y les guiaba también otra convicción: la de que a la historia del género épico le viene faltando desde hace años un nuevo capítulo, quizás el último, uno que sería verdaderamente épico y que incluiría a 
Assim, pode-se dizer que Débora e Vilnius percebiam que obras de escritores como Enrique Vila-Matas eram capazes de se aproximar da verdade de um modo como jamais os escritores realistas que tentavam mimetizar o real conseguiriam. $\mathrm{O}$ autor espanhol sempre foi desses que estiveram afogados até o pescoço no mundo da ficção. Sua vida, como a vida de todos nós, sempre teve algo de fictício, e sua ficção sempre esteve repleta de préstimos de sua vida real. Esta é uma das razões pelas quais o autor se tornou exemplo de personalidade múltipla. Ele, a todo o momento, jogou com o fato de ser e não ser os seus narradores, os seus personagens, as suas invenções. A todo o momento foi real e foi fictício simultaneamente.

Ao conferir este ar ficcional também à vida de seus personagens, estes paradoxalmente - acabam se tornando mais reais aos olhos do leitor. Suas vidas se convertem no que é a vida de todos nós, a extensão de um palco onde, sem nos darmos conta, agimos e interagimos como atores que seguem os roteiros inimagináveis escritos pela vida.

É justamente este o principal papel do teatro e da ficção: ressaltar as verdades ocultas na realidade e despertar no público a percepção de que os espetáculos representados no palco nada mais são do que variações da vida cotidiana. Do mesmo modo que acontece na tragédia de Shakespeare, na qual Hamlet e os demais personagens - ainda que se imaginem meros espectadores de uma representação teatral - acabam sendo, na verdade, os personagens principais, uma obra de arte pode levar o espectador a perceber que ao entrar em contato com determinadas obras, não está se conectando apenas com a vida e a história de personagens nela representada, mas com a sua própria.

O que Vila-Matas faz em Aire de Dylan é tornar estes níveis de recepção mais complexos ao inserir uma peça, que tem como um dos momentos principais a execução de outra peça, dentro de mais um texto ficcional. Aqui, vida é teatro, memória é teatro dentro do teatro. São ficções dentro de ficções. São também obras que despertam no leitor a consciência de que suas vidas também fazem parte desse conjunto de bonecas russas em que realidade e ficção se fundem.

todos aquellos narradores que lucharon con esfuerzo titánico contra toda forma de fingimiento o de impostura y cuya lucha tuvo siempre un evidente acento paradójico, pues quienes así combatieron fueron escritores que vivieron anegados hasta el cuello en el mundo de la ficción: artistas que buscaron el modo de decir o de aproximarse a la verdad a través de ella, a través de la ficción, logrando que al menos de esa tensión estilística sugieran las mayores aproximaciones a la verdad que se conocen hasta ahora" (VILAMATAS, 2012, págs. 180/181). 


\subsection{Metamorfoses}

Em 2011, Vila-Matas publica uma coletânea intitulada En un lugar solitário, que reúne seus cinco primeiros livros. Neste volume, o escritor analisa, agora já sob a perspectiva de um reconhecido e experiente autor, os processos pelos quais sua produção literária passou. $\mathrm{O}$ autor comenta como seu modo de encarar e escrever romances mudou ao longo do tempo. Quando analisa, por exemplo, Al sur de los párpados, o escritor fala de três Vila-Matas diferentes, que lidavam de formas distintas com aquele livro. Primeiro, o autor que escreveu o romance, depois, o que durante anos tentou proibir que qualquer pessoa o lesse e, por último, o que trinta anos depois, volta a abrir o seu exemplar e percebe que apesar de aquele romance não o haver ensinado a escrever, o havia ensinado o que era e o quão dura era a vida de um romancista.

Este último reconhece ainda que, mesmo trabalhados de forma ainda bem imaturas, certos detalhes que lhe acompanharam em sua produção já se faziam latentes em sua escritura. Neste prólogo intitulado No hay que hacer nada luego, o autor reflete ainda sobre sua juventude e sobre as transições pelos quais ele e sua obra passaram, sobre a responsabilidade de deixar de ser alguém que poderia escrever quando e o que tivesse vontade, para se tornar o que seu destino o chamava a ser: escritor. As reflexões levantadas neste prólogo também são abordadas em Aire de Dylan, agora, em forma de ficção.

Vila-Matas, bem como Hamlet e Bob Dylan - e mesmo antes de passar por diversas metamorfoses e alcançar a multiplicidade que só o passar dos anos pode proporcionar - foi sempre um escritor ambíguo, extremante paradoxal que soube ser vários em um, conferindo a si e suas obras um caráter inclassificável. Aire de Dylan é então a obra em que o autor se dedica a fazer uma autoanálise de toda a sua produção e das várias personalidades adotadas por ele dentro e fora dela.

Assim, se ao analisar Al sur de los párpados, o autor se depara com versões diferentes dele mesmo, em Aire de Dylan ele dá continuidade a este processo de autoanálise tendo seus personagens como mecanismo. Neste sentido, o romance se distancia da maioria de seus textos, nos quais quase sempre se nota uma forte dose de autoficção, mas que parte maiormente de seus narradores, não raramente escritores barceloneses que se dedicam também a explorar outros artistas e obras dentro de suas ficções. 
Este é sim mais um romance no qual o autor trata do tema da identidade, e claro, trabalhando sobretudo a sua própria. Entretanto, não busca unicamente descrevê-la, mas acima de tudo conhecê-la melhor. No prólogo de En un lugar solitário ele afirma:

\begin{abstract}
Me incomoda que alguém, depois de ler um texto meu, pudesse chegar a acreditar que já sabia algo de mim. Porque, se pensar bem, eu sempre escrevi me ocultando, dando falsas pistas e ao mesmo tempo oferecendo ao leitor aspectos insólitos de minhas diferentes personalidades, todas verdadeiras. Nada me incomoda mais que saber quem sou, ainda que a tensão de minha escritura procede daí, pois vem sempre da obstinada, quase compulsiva, busca de minha identidade mais única, também a mais próxima da ficção, ainda que ao mesmo tempo, paradoxalmente, a mais próxima da verdade. ${ }^{36}$
\end{abstract}

Aire de Dylan é então, mais uma de suas ficções convertidas em espaço de busca por sua identidade e é, entre todas, a obra na qual esta busca se torna mais complexa, já que passeia por toda sua vida: de seus anos de juventude e aprendizagem, até o seu presente como escritor consagrado.

A principal diferença entre este romance e seus escritos anteriores é que sua voz não se faz presente somente pelo narrador, escritor tão experiente como ele, mas também por outros dois personagens centrais: Vilnius e Juan Lancastre. Assim, não é apenas o veterano escritor que tem espaço para lançar suas reflexões sobre arte, literatura e até mesmo para refletir quem ele foi e quem se tornou. Existe um diálogo entre o jovem e o maduro Vila-Matas, no qual um pode opinar sobre a vida e as opiniões do outro. Deste modo, partimos da hipótese de que estes três personagens, narrador, Juan e Vilnius Lancastre, representam momentos diferentes da carreira de Vila-Matas.

Apesar dos vários conflitos e da diversidade de opinião entre os personagens, também são diversos os pontos que os unem entre si e entre Vila-Matas. Juan Lancastre, por exemplo, revela que também não sabe quem é, não conhece profundamente sua identidade, e que esta dificuldade em conhecer a si próprio pode ser ainda mais manifesta na vida de escritores:

\footnotetext{
36 "Me molesta que alguien, tras leerme, pudiera llegar a creer que ya sabía algo de mí. Porque, si piensa bien, yo siempre he escrito ocultándome, dando falsas pistas y al mismo tiempo ofreciendo al lector aspectos insólitos de mis diferentes personalidades, todas verdaderas. Nada me molestaría más que saber quién soy, aunque la tensión de mi escritura procede de ahí, pues viene siempre de la empecinada, casi obsesiva, búsqueda de mi identidad más única, también la más próxima a la ficción, aunque al mismo tiempo, paradójicamente, la más cercana a la verdad" (VILA-MATAS, 2011, p. 14).
} 
Uma pessoa nunca sabe quem é. São os demais que lhe dizem quem e o que é. Te explicam tantas vezes quem é você e de formas tão diferentes, que ao final você acaba não sabendo quem é você. Todos dizem algo diferente sobre você. Inconcluso você mesmo está sempre mudando de opinião. Se a isso acrescentamos que uma pessoa se esforça para surpreender os outros sendo várias pessoas ao mesmo tempo, o que na verdade acaba acontecendo é que terminamos não tendo nem a menor noção de quem somos ou poderíamos ter sido. $^{37}$

O próprio autor, seja em seus artigos e ensaios ou por meio dos personagens de seus romances, já afirmou que não se sente muito confortável quando os críticos ou seus leitores de modo geral tentam definir quem é Vila-Matas, quando nem mesmo ele tem esta resposta. Porém, tendo em vista que suas obras quando publicadas também passam a estar nas mãos de seus leitores, é inevitável que estes realizem leitura não apenas da obra que têm em mãos, mas também de seu criador, ainda mais se este se fizer tão presente em seus personagens e no enredo que narram.

Em Aire de Dylan, também há espaço para o autor refletir como diversas leituras realizadas pelo público e pela crítica acabaram se tornando mais um elemento que influenciou na construção de sua identidade (ou identidades). Por um lado, houve leituras que o fez perceber que realmente poderia ser interessante explorar novas possibilidades, por outro, certas leituras reforçavam seu interesse de criar obras transgressoras que jamais agradaria a certos críticos.

O gosto pela transgressão é mais um ponto que une Vila-Matas aos três personagens de seu romance. Mesmo Vilnius, que não poucas vezes havia se posicionado contra seu pai, se vê forçado a defendê-lo ante Max, amante de sua mãe e personagem que em diversos momentos ocupa o papel que a crítica espanhola desempenhou na vida do autor. Diz Vilnius a Max:

Mas, Max, por Deus, todo mundo sabe que Juan Lancastre não foi nunca inimigo do narrativo. Na verdade, o que fazia era tratar de mover as coisas paralisadas; provocava as vezes só para pôr em questão o que o cânone espanhol toma tontamente como sério e bom. Fazia coisas assim, mas não estava contra o narrativo, pelo contrário. Agitava tudo o que podia, demonstrava que se podiam fazer coisas diferentes, que não havia leis

\footnotetext{
37 'Uno nunca sabe quién es. Son los demás los que le dicen a uno quién y que es. Te explican tantas veces quién eres y de formas tan distintas, que al final uno acaba por no saber en absoluto quién es. Todos dicen de ti algo diferente. Inconcluso uno mismo está siempre cambiando de opiniones. Si a eso añadimos que uno se esfuerza por sorprender a los otros siendo varias personas al mismo tiempo, lo que en verdad acaba sucediendo es que terminamos no teniendo ni la menor noción de quién somos o podríamos haber sido" (VILA-MATAS, 2012, p. 157).
} 
imutáveis nisso de literatura e menos ainda nas leis espanholas, tão antiquadas. $^{38}$

Aqui fica claro que Juan Lancastre não apenas era contemporâneo a Vila-Matas, como também compartilhava seu desejo de inovar a literatura rompendo com o cânone espanhol. Neste ponto, até mesmo Vilnius estava em acordo com seu pai. Outro aspecto que aproximava pai e filho era que, do mesmo modo que o jovem Vila-Matas quando era ainda um escritor iniciante, o rapaz desde cedo já se posicionava contra os preceitos do realismo:

Vou te explicar, Max. Há um realismo para o qual o próprio realismo é um gênero como qualquer outro, não o componente essencial da criação. Esse gênero realista é uma convenção morta, relacionada a um certo tipo de trama tradicional, com princípios e finais previsíveis, com diálogos tópicos, com marquesas que saem de casa às cinco da tarde e tudo isso. ${ }^{39}$

Desta vez, Vila-Matas optou por delegar estas palavras a um de seus personagens, neste caso Vilnius, mas as mesmas poderiam muito bem haver sido ditas em algum de seus artigos ou ensaios nos quais revela suas opiniões sobre uma literatura que se propõe realista.

Entretanto, se por um lado Vilnius mantém estas semelhanças com seu pai, com o narrador do livro e com Vila-Matas; por outro, o jovem desacreditava no estilo de vida que os três maduros escritores adotaram, dedicando-se arduamente à literatura e lutando sempre para produzir obras superiores às que haviam produzido anteriormente. Sobre esta incansável busca, Vilnius diz:

Se colocava como exemplo sempre de homem feito a si próprio e trabalhador infatigável. Um tipo espantoso e ao mesmo tempo um homem comovente. Levou muito a sério sua carreira e a possibilidade de chegar a algo através dela.

\footnotetext{
38 “Pero, Max, por Dios, todo el mundo sabe que Juan Lancastre no fue nunca enemigo de lo narrativo. Más bien lo que hacía era tratar de mover cosas estancadas; provocaba a veces sólo para poner en cuestión lo que el canon español da tontamente por serio y bueno. Hacía cosas así, pero no estaba contra lo narrativo, ni muchísimo menos. Agitaba todo lo que podía, demostraba que se podían hacer cosas diferentes, que no había leyes inmutables en esto de literatura y menos aún en las leyes españolas, tan rancias" (VILAMATAS, 2012, p. 67).

39 “Te lo voy a explicar, Max. Hay un realismo para el que el propio realismo es un género como cualquier otro, no el componente esencial de la creación. Ese género realista es una convención muerta, relacionada con un cierto tipo de trama tradicional, con principios y finales previsibles, con diálogos tópicos, con marquesas que salen de casa a las cinco de la tarde y todo eso" (VILA-MATAS, 2012, p. 69).
} 
Tinha a ideia de que progredia dia a dia, de que avançava em um bosque em direção à luz. Desde cedo era comovente. E também patético. ${ }^{40}$

Talvez aquele jovem Vila-Matas que escreveu seu primeiro livro, Mujer en el espejo contemplando el paisaje, enquanto cumpria serviço militar em Melilha e que depois ainda chegou a escrever outros livros, antes de se dar conta que a vida de um escritor realmente comprometido com sua produção poderia ser extremamente árdua, compactuaria com a opinião de Vilnius.

Logo após o jovem cineasta falar de sua opinião sobre o estilo de produção que seu pai seguia, Lancastre parece infiltrar-se novamente em sua mente lhe introduzindo memórias:

\begin{abstract}
Vilnius foi reconstruindo em silêncio umas palavras que Lancastre lhe havia dito alguns meses antes de morrer quando lhe disse que na realidade uma pessoa sempre desejava melhorar escrevendo, caso contrário seria para ficar louco... Se tratava, the havia dito seu pai aquele dia, de um fenômeno que aparecia com a idade. Alguém sentia de repente que suas criações haviam de ser cada vez mais rigorosas, ainda que soubesse, ao mesmo tempo, que o rigor lhe iria matar o frescor, a genialidade juvenil, a vitalidade do bruto ignorante, a raiva rebelde. ${ }^{41}$
\end{abstract}

Se antes temos uma opinião que parece ser a do jovem Vila-Matas referindo-se a um tipo de escritor que ele mesmo, sem saber, viria a ser, agora temos uma resposta de sua versão muito mais experiente para aquele jovem. É desta forma, criando o diálogo entre algumas das diversas personalidades que assumiu ao longo de sua vida, que VilaMatas desenvolve mais uma narrativa que é também espaço para investigar sua identidade e se aproximar um pouco mais da resposta que ele busca, provavelmente sem o intuito de chegar a uma verdade definitiva e limitadora, de quem ele realmente é.

Este é mais um romance no qual o caráter autoficcional e a conexão com diversas obras de outros autores se faz presente. A escolha por trazer Hamlet para o universo de sua narração, aproximando-a do universo cênico, já é em si mais uma escolha que

\footnotetext{
40 "Se ponía como ejemplo siempre de hombre hecho a sí mismo y de trabajador infatigable. Un tipo espantoso y al mismo tiempo un hombre conmovedor. Se tomó muy en serio su carrera y la posibilidad de llegar a algo en ella. Tenía la idea de que progresaba día a día, de que avanzaba en un bosque hacia la luz. Desde luego era conmovedor. Y también patético" (VILA-MATAS, 2012, p. 165).

41 "Vilnius fue reconstruyendo en silencio unas palabras que le había dicho Lancastre unos meses antes de morir cuando le habló de que en realidad uno siempre anhelaba mejorar escribiendo, pues si no sería para volverse loco... Se trataba, le había dicho su padre aquel día, de un fenómeno que aparecía con la edad. Uno de pronto sentía que sus creaciones habían de ser cada día más rigurosas, aunque supiera, al mismo tiempo, que el rigor iba a matarle la frescura, la genialidad juvenil de primera hora, la vitalidad del bruto ignorante, la rabia rebelde" (VILA-MATAS, 2012, p.165).
} 
intensifica este atributo autoficcional, visto que a própria obra de Shakespeare já guarda semelhanças com a vida pessoal de seu criador, que assim como seu personagem principal também havia acabado de perder o pai. Hamlet é um pouco de Shakespeare do mesmo modo como Vilnius, Juan Lancastre e o narrador de Aire de Dylan são um pouco de VilaMatas.

Mas então um romance poderia levar seu autor a descobrir quem realmente é? E afinal de contas quem é Vila-Matas de verdade? Quem é Bob Dylan? Ele é mais Robert Zimmerman, mais o cantor folk, mais o cantor que "traiu o folk" ao trocar seu violão pela guitarra elétrica, mais o Nobel de literatura ou tudo isso e muito mais? Quem é Duchamp? Quem sou eu? Quem é você? A resposta, meu amigo, está soprando no vento. Ler, escrever, viajar, pode nos levar a encontrarmos com nós mesmos, pode dar pistas de quem somos, mas quanto a resposta... ela não é tão importante. 


\subsection{Filosofia da composição dadaísta}

Em seu ensaio Filosofia da composição (1845) Edgar Allan Poe (1809 - 1849) comenta sobre os métodos que o verdadeiro artista deveria utilizar na constituição de uma obra de arte. $\mathrm{O}$ autor afirma que tais métodos haveriam sido utilizados por ele na elaboração de seu célebre poema $O$ corvo (1945).

Segundo Poe, pensando mais especificamente no caso do poeta, mas estendendose também a qualquer criador de ficção, o bom artista deve ter consciência de uma série de fatores antes mesmo de dar início ao seu trabalho. $\mathrm{O}$ artista deve ter em mente desde a extensão que sua obra terá, até o efeito que esta atingirá, de modo que tema e acontecimentos sejam trabalhados em harmonia de forma a auxiliar na construção do efeito pretendido.

Sendo assim, um autor já deve iniciar sua produção sabendo tudo o que quer dizer para que sua obra não seja mero fruto do acaso e de sua intuição. Sobre a composição de O corvo Poe afirma: "É meu desígnio tornar manifesto que nenhum ponto de sua composição se refere ao acaso, ou à intuição, que o trabalho caminhou, passo a passo, até completar-se, com a precisão e a sequência rígida de um problema matemático" (POE, 1999, p. 102).

Esta filosofia da composição proposta pelo autor norte-americano é totalmente oposta ao método que Vila-Matas e boa parte dos artistas admirados e ficcionalizados por ele, como Marcel Duchamp, adotaram em suas produções. Ainda no prólogo de En un lugar solitário, o autor comenta que, ao escrever seu primeiro, livro utilizou as únicas leis líricas que conhecia até então, criando um "monólogo de escritura automática acerca de todo lo que buenamente fuera dictándome la inspiración" (VILA-MATAS, 2011, p. 12).

Ao analisar suas primeiras produções tantos anos depois, o autor continua considerando legítimo o método que adotou em sua primeira produção literária:

\footnotetext{
Nada vejo de mal nesse método empregado para meu primeiro livro, pelo contrário. No final das contas, como disse J.M. Coetzee, uma das coisas que a gente não costuma compreender dos escritores - os escritores sérios, pelo menos, é que não se começa por ter algo sobre o que escrever e então se escreve sobre isso, mas que é o processo de escrever propriamente dito que permite ao autor descobrir o que quer dizer. ${ }^{42}$
}

\footnotetext{
42 "Nada veo de malo en ese método empleado para mi primer libro, sino todo lo contrario. A fin de cuentas, como dijo J.M. Coetzee una de las cosas que la gente no suele comprender de los escritores - los escritores serios, por lo menos - es que uno no empieza por tener algo de lo que escribir y entonces escribe sobre ello,
} 
Esta ideia conecta-se com as ideias de Duchamp, que em diversos momentos, inclusive na entrevista concedida a Cabanne, admitiu que antes de se preocupar com a interpretação de suas obras e as mensagens que estas poderiam transmitir, lhe interessava mais a execução em si. Entre estas obras está uma das quais mais se discutiu e se discute acerca de seus possíveis significados: o Grand Verre.

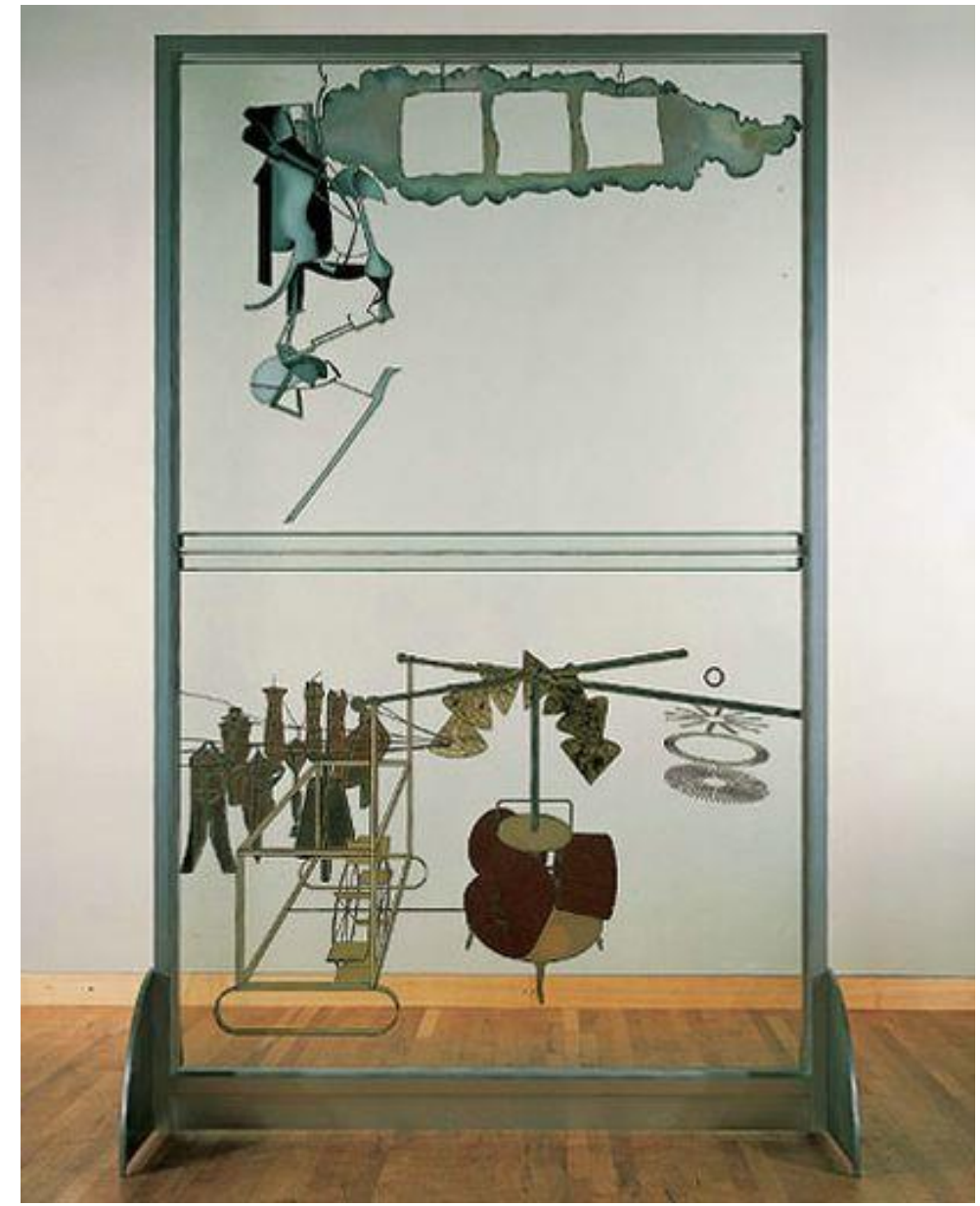

Figura 4 - DUCHAMP. Gran Verre, 1915-1923

Quando questionado por Cabanne sobre a interpretação que ele tinha de sua própria obra ele responde:

Não a tenho porque a fiz sem ter uma ideia concreta. Eram coisas que iam se apresentando a medida em que se ia fazendo a obra. A ideia global é, pura e simplesmente, a execução; se acabaram as descrições tipo catálogo das Armas

sino que es el proceso de escribir propiamente dicho el que permite al autor descubrir lo que quiere decir" (VILA-MATAS, 2011, p. 12). 
de Saint-Etienne sobre cada parte. Era uma renúncia a toda estética, no sentido normal da palavra. ${ }^{43}$

De uma forma diferente, mas ainda conexa com o modo de produção de Duchamp, Vila-Matas também se dedicou a ir contra a realidade lógica e fez da sua escritura muito mais do que um espaço sério onde se reflete seriamente a realidade. Ele, como Duchamp, se permitiu divertir durante o trabalho. O trabalho de ambos é prova de que literatura e arte podem abordar temas complexos e provocar reflexões mesmo quando não levam a si próprias tão a sério.

43 "No la tengo porque lo hice sin tener una idea concreta. Eran cosas que se iban presentando, a medida que se iba haciendo la obra. La idea global es, pura y simplemente, la ejecución; se acabaron las descripciones tipo catálogo de las Armas de Saint-Etienne sobre cada parte. Era una renuncia a toda estética, en el sentido normal de la palabra" (DUCHAMP apud CABANNE, 2001, p. 35). 
4. POR TERRENOS DESCONHECIDOS 


\subsection{Trajetórias Shandys}

Happiness is not the road that leads somewhere. Happiness is the road itself ${ }^{44}$

Bob Dylan

Segunda década do século XX, o continente europeu ainda sofria os desastrosos efeitos da primeira guerra mundial quando já passava a sentir os prenúncios da segunda. É nesse cenário, marcado por delimitações e conflitos territoriais, que uma série de artistas se une para também entrar em combate, dessa vez, o interesse não é proteger fronteiras, mas destruí-las, romper com toda e qualquer forma de limitação.

Em total contraste com austera realidade daqueles dias, estes artistas instauram uma sociedade secreta que tinha como maior desígnio exaltar a leveza e o portátil na arte e na vida. A sociedade chama-se Shandy, nome que incorpora em muitos aspectos o espírito dessa conspiração que surgia como um relâmpago da insolência, pronta para transgredir qualquer limite. Além de ser uma homenagem ao também explosivo e insolente Tristam Shandy, de Sterne, este nome também poderia traduzir-se como alegre, louco e volúvel.

É sobre os percursos percorridos pelos Shandys que nos conta o narrador de Historia abreviada de la literatura portátil, um admirador e investigador do shandysmo que examinou obras e documentos relacionados à conspiração e chegou até mesmo a conversar com um de seus membros, Marcel Duchamp, a fim de revelar alguns dos mistérios ainda desconhecidos daquela sociedade secreta que teve sua existência exposta ao mundo, e consequentemente seu fim, em 1927.

A sociedade secreta surge em 1924, de forma leve e ligeira, como uma mala preparada às pressas, mas que contém tudo o que um viajante precisa para percorrer diversos caminhos sem que sua bagagem se torne um fardo e diminua o prazer ou o dinamismo da viagem. Não é em vão que a boîte-envalise de Duchamp logo se converteu em emblema da literatura portátil e da conspiração shandy, já que essa obra que trazia reproduções em miniaturas de outras obras duchampianas, representava não apenas o espírito nômade daqueles artistas, mas também o encanto que as miniaturas lhes despertavam.

\footnotetext{
44 “A felicidade não é a estrada que leva a algum lugar. A felicidade é a própria estrada.”
} 
Desde o início, foram estipulados alguns princípios que todos os que estivessem interessados em formar parte da conspiração deveriam seguir. Nos conta o narrador que para alguém ser considerado um artista shandy, antes de tudo, era necessário que este apresentasse um alto grau de loucura. Cumprido esse requisito, um candidato a shandy também deveria ser ou funcionar como uma perfeita máquina solteira, já que as obrigações e preocupações com filhos ou matrimônios poria em risco o estilo de vida nômade, libertino e despreocupado que a conspiração pregava. Outro requisito indispensável era possuir uma obra portátil, que não fosse pesada, coubesse facilmente e pudesse ser facilmente transportada a qualquer lugar. Além destes requisitos indispensáveis, conhece-se também uma série de exigências de características recomendáveis:

\begin{abstract}
Ainda que não indispensáveis, recomenda-se também possuir certas características que eram considerados como tipicamente shandys: espírito inovador, sexualidade extrema, ausência de grandes propósitos, nomadismo infatigável, tensa convivência com a figura do duplo, simpatia pela negritude, cultivar a arte da insolência. ${ }^{45}$
\end{abstract}

Um artista que apresentasse todas essas características estaria certamente apto a propagar o espírito shandy por onde quer que passasse e, apesar do clima na Europa daquele momento ser extremamente pesado e contrastivo com esse espírito, não foi difícil reunir uma série de artistas excêntricos, prontos para entrar em movimento e produzir mais obras portáteis, ansiosos para combater rígidos e velhos mecanismos.

Porém, antes que partissem para a primeira viagem, Walter Benjamin criou sua máquina risonha de pesar livros. Benjamin se deu conta que a criação era necessária depois que começaram a surgir diferentes adaptações da Boîte-em-valise duchampiana, muitas vezes realizadas pelos próprios shandys. Estes, eram artistas que não se importavam em ver suas obras sendo transgredidas, afinal, além de também serem transgressores, lhes agradavam o fato de suas criações estarem abertas para interagir com ideias de outras pessoas. No entanto, era necessária uma precaução para que o emblema shandy não chegasse ao alcance de qualquer farsante.

A máquina risonha de Benjamin torna-se então uma das mais importantes criações shandys, uma máquina que ainda hoje permite detectar quais livros são realmente

\footnotetext{
45 "Aunque que no indispensables, se recomendaba también poseer ciertos rasgos que eran considerados como típicamente shandys: espíritu innovador, sexualidad extrema, ausencia de grandes propósitos, nomadismo infatigable, tensa convivencia con la figura del doble, simpatía por la negritud, cultivar el arte de la insolencia" (VILA-MATAS, 1985, p. 13).
} 
portáteis e quais, ainda que tentem se passar por ligeiros e portáteis, são na verdade livros insuportáveis e, consequentemente, intransportáveis.

Os primeiros shandys realizam sua primeira viagem para Port Actif, na África. Nos conta o narrador que, ao chegar naquele destino, nenhum dos viajantes compreendia o que fazia ali. Entre todos, Francis Picabia era o mais otimista e buscava insensatamente por um sinal que indicassem aos shandys a razão daquela viagem. É certo que o motivo pelo qual Picabia buscava nas ruas e no céu sinais que justificassem àquela viagem, era o fato de ter sido ele o responsável por animar aos demais a embarcar nessa aventura.

Duchamp, Ferenc Szalay, Paul Morand e Jacques Rigaut, além de Picabia, eram os cincos membros daquela sociedade secreta, ainda incipiente, que participavam da viagem. Quando todos, inclusive Picabia, já se sentiam entediados e passavam a aceitar que aquela, bem como toda viagem, corria o risco de carecer de sentido, uma mulher fatal surge em seus caminhos. Tratava-se de Georgia O'Keefe, pintora e escultora americana que introduz ao shandysmo o conceito de sexualidade extrema, conceito este que harmonizava totalmente com o preceito básico de funcionar como uma máquina solteira, visto que visava o puro prazer, e jamais a descendência ou qualquer outro fim.

Esse encontro com O'Keefe foi primordial para a consolidação da sociedade secreta. A partir daquele encontro, os viajantes não só encontraram um sentido para aquela viagem como também conceberam melhor o espírito do shandysmo. E assim, filha do equívoco e do acaso, nasceu a sociedade que representou o sopro e a aura do século XX.

Logo, a conspiração já contava com muito mais do que os cinco membros que estiveram em Port Actif e, cada vez mais numerosa, mantinha-se em movimento como uma brisa misteriosa e infraleve, soprando por cidades e países sem nunca saber exatamente o que encontrar, mas sempre encontrando algo, ainda que fosse apenas perguntas.

Nessa caminhada, chegaram também a Viena, onde com muito esforço e descrição conseguiram realizar uma festa para celebrar o encontro de tantas almas portáteis e audaciosas. Sobre esta festa, o narrador destaca o episódio que por pouco não abreviou ainda mais a existência daquela sociedade secreta. Depois de muita diversão e conversas regadas a álcool, o criado do anfitrião da festa, tomado pela empolgação, efetuou uma série de disparos de arma de fogo contra o teto.

O anfitrião era Werner Littbarski, um incômodo frequente para seus vizinhos devido seu costume de realizar festas extremante barulhentas nas quais os únicos 
presentes eram ele e seu criado. Apesar da vizinhança já ser acostumada com estas festas um tanto loucas promovidas por Littbarski, já desconfiavam que dessa vez tanto barulho não pudesse ser causado por um homem só. Os shandys tiveram que sair pelos fundos e rapidamente se esvanecer pela noite vienense para garantir mais tempo de vida para a conspiração. Apenas Scott Fitzgerald permanecia no local quando a polícia chegou. E os eventos vivenciados naquela noite se tornam também inspiração para a escrita do romance que o autor publicou naquele mesmo ano: O Grande Gatsby (1925).

Durante a fuga desesperada, Walter Benjamim foi quem garantiu que os artistas não se dispersassem de forma definitiva, convocando a todos para um novo encontro, dessa vez em Praga. Entretanto, ainda que o espírito shandy fosse um espírito alegre e viajar representasse para eles se encontrar como uma série de prazeres, a vida de um artista nem sempre é fácil e foi em Praga que os caminhos shandys se tornaram mais sinuosos e sombrios.

Ser escritor e ser artista é também ser dono de angústias. É muitas vezes a angústia que leva o artista a produzir, às vezes pela necessidade de retratar o que sente, outras vezes, como forma de procurar alívio. No entanto, muitas vezes é o próprio processo de produção de uma obra o que pode haver de mais angustiante na vida de um artista. E ali em Praga foi onde cada shandy começou a ser atormentado por pequenas criaturas que causavam forte aflição a todos. Tratavam-se de criaturas que poderiam ou não assumir a forma humana, mas que estavam ali para inquietar aqueles artistas.

Kafka, em distintos momentos soube traduzir como ninguém o sentimento de angústia, assim, nada mais justo que aquelas criaturas responsáveis por afligir os shandys fossem nomeadas com o nome de uma criatura mencionada em um de seus contos, no caso, As preocupações de um pai de família, presente em Um médico rural (1919). Estas criaturas foram chamadas então de odradeks.

Um dos shandys, Stephan Zenith, totalmente atormentado após se deparar com seu odradek pela primeira vez, decide ir embora de Praga imediatamente, deixando um bilhete a Gombrowicz, que foi seu companheiro de quarto durante aquela viagem. Em nenhum momento Zenith ou o próprio narrador, quando nos conta sobre esse bilhete destinado a Gombrowicz, menciona o conto de Kafka, mas é impressionante como, ao descrever a criatura que o atormenta, Zenith utiliza algumas palavras que são exatamente as mesmas utilizadas por Kafka que assim descreve ao odradek: 
À primeira vista ele tem o aspecto de um carretel de linha achatado e em forma de estrela, e com efeito parece também revestido de fios; de qualquer modo devem ser só pedaços de linha rebentados, velhos, atados uns aos outros, além de emaranhados e de tipo e cor dos mais diversos. Não é, contudo, apenas um carretel, pois do cento da estrela sai uma varetinha e nela se encaixa depois uma outra, em ângulo reto. Com a ajuda desta última vareta de um lado e de um dos raios da estrela do outro, o conjunto é capaz de permanecer em pé como se estivesse sobre duas pernas. Alguém poderia ficar tentado a acreditar que essa construção teria tido anteriormente alguma forma útil e que agora ela está apenas quebrada. Mas não parece ser este o caso; pelo menos não se encontra nenhum indício nesse sentido; em parte alguma podem ser vistas emendas ou rupturas assinalando algo dessa natureza; o todo na verdade se apresenta sem sentido, mas completo à sua maneira. Aliás não é possível dizer nada mais preciso a esse respeito, já que Odradek é extraordinariamente móvel e não se deixa capturar. (KAFKA, 1994 p. 41-42).

O odradek de Stephan Zenith também possuía a forma de um carretel de linha em formato de estrela. Ao tentarem entender o que era aquela criatura, tanto o personagem kafkiano quanto o shandy tentaram estabelecer um diálogo com ela, no entanto, ambos obtêm a mesma reposta:

Ele se detém alternadamente no sótão, na escadaria, nos corredores, no vestíbulo. Às vezes fica meses sem ser visto; com certeza mudou-se então para outras casas; depois, porém volta infalivelmente à nossa casa. Às vezes quando se sai pela porta e ele está inclinado sobre o corrimão logo embaixo, tem-se vontade de interpelá-lo. É natural que não se façam perguntas difíceis, mas sim que ele seja tratado - já que o seu minúsculo tamanho induz a isso - como uma criança. "Como você se chama?", pergunta-se a ele. "Odradek", ele responde. "E onde você mora?" "Domicílio incerto" diz e ri; mas é um riso como só se pode emitir sem pulmões. Soa talvez como o farfalhar de folhas caídas (KAFKA, 1994, p. 41).

Apesar do odradek de Zenith ser igual ao descrito por Kafka, praticamente transposto da ficção kafkiana para a realidade shandy, cada membro da conspiração começou a encontrar odradeks que assumiam as mais distintas formas. Foi nos labirintos de Praga que a presença desses seres enigmáticos se tornou tão imponente e angustiante para os membros da conspiração.

E não era só externamente que estes seres invadiam a vida dos shandys. Muitas vezes o odradek não precisava assumir a forma de nenhum objeto para romper com a paz daqueles artistas. Não demorou para que aparecem relatos de membros atordoados, que começavam a temer a si próprios porque sabiam que haviam odradeks habitando em seus interiores. Assim, suas mentes já guardavam não somente suas memórias, mas um palimpsesto de memórias próprias mescladas a memórias de odradeks.

Porém, ainda que estes seres tenham causado espantoso desconforto à vida dos artistas que, até aquele momento levavam alegremente a vida de viajantes infatigáveis, a 
aparição dos odradeks também trouxe aspectos positivos para a conspiração. Por um lado, era pavorosa a ideia de que inquilinos negros, como também denominaram os odradeks, aparecessem do nada, prontos para acabar com a normalidade da vida dos shandys, chegando a ameaçar a destruí-la como destrói a normalidade da vida da família do conto de Kafka. Por outro lado, romper com a normalidade, com tradições e rotinas, era o objetivo basilar do shandysmo, de modo que aceitar a existência destes seres e travar com eles uma tensa convivência, era mais um modo de levar uma vida não convencional.

Enquanto shandys e odradeks seguiam em tensa convivência, foi revelado um dos grandes segredos daquelas criaturas enigmáticas: elas também eram atormentadas por outras criaturas, os golems, que operavam de modo semelhante aos próprios odradeks, lhes causando a mesma inquietação que eles causavam aos portáteis. Não demorou para que se descobrisse que os golems, por sua vez, também possuíam um lado duplo, os bucarestis, "criaturas originárias da Romênia, parentes pobres do Conde Drácula e perseguidores implacáveis dos golems dos odradeks"46.

Assim, como bonecas russas, cada inquilino negro possuía seus próprios inquilinos negros do mesmo modo que na escrita de todo livro há sempre as marcas de textos que seu autor leu e que, por sua vez, também foram frutos de experiências extraídas de outras leituras e outros textos.

Apesar das dificuldades, seguindo a ideia de alcançar as melhores condições para que seus trabalhos não parassem, os portáteis continuam de viagem. E os caminhos shandys passam não apenas por cidades e lugares habituais, mas também por lugares cuja excentricidade conecta-se fortemente com o próprio espírito portátil. Desta forma, um sanatório e um submarino imóvel foram alguns dos lugares que fizeram parte das trajetórias shandys.

O percurso também passa pela aprazível cidade de Trieste, cidade cujo clima ameno se opunha totalmente ao cenário nebuloso de Praga, fazendo com que os inquietos conspiradores acreditassem que ali poderiam se ver livres da perseguição de seus odradeks. No entanto, já não importava para onde iam, estes artistas, por mais que fossem acostumados com a solidão de quem vive como uma máquina solteira, já não conseguiam se manter verdadeiramente sozinhos.

Sem encontrar a paz que buscavam em Trieste, os viajantes seguiram para Paris. $\mathrm{O}$ investigador-narrador relata que na cidade luz surgiram os primeiros elogios à preguiça

\footnotetext{
46 “criaturas originarias de Rumania, parientes pobres del Conde Drácula y perseguidores implacables de los golems de los odradeks" (VILA-MATAS, 1985, p.72).
} 
por parte dos portáteis, e que foi ali, em seu país natal, que Duchamp afirmou que o parasitismo era uma das Belas Artes.

No entanto, antes que a sociedade fosse traída e seus membros se dispersassem ou para continuar produzindo, ou para iniciar um estilo bartlebyano de vida, era necessário seguir com os planos e continuar funcionando como máquinas solteiras, afim de que nenhuma preocupação de uma vida comum atrapalhasse os portáteis a seguir trabalhando.

Para se afastarem dos pensamentos sobre como uma vida ociosa poderia ser maravilhosa, os artistas decidiram se submergir, literalmente, no trabalho. Assim, uma das últimas viagens dos portáteis como uma conspiração foi em um submarino, o Banhof $z o o$, que ironicamente não podia se mover. Aquela viagem imóvel foi primordial para aflorar as ideias dos artistas.

Ninguém, nem mesmo o investigador-narrador, sabe afirmar qual foi o motivo pelo qual os portáteis abandonaram o submarino, mas pouco depois de voltarem à terra firme, mais precisamente à Espanha de 1927, durante a homenagem a Góngora que inaugurou a geração de 27, Alaister Crowley deu a conhecer ao mundo a existência daquela sociedade. Perplexos com a traição, mas felizes por saberem que uma história de sociedade secreta não se faz sem traidores, os shandys puderam finalmente se revelar e tornar ainda mais estrondoso o relâmpago da insolência que eles vieram para propagar.

A conspiração acabou no dia da traição pública, mas o espírito shandy continuou percorrendo os quatro cantos do mundo. Como tiveram seus heróis, indispensáveis no despertar de seus interesses artísticos e na elaboração de seus trabalhos, agora os portáteis se convertiam em heróis de outras gerações, inspiração para novos artistas transgressores e infraleves.

Deste modo, o sopro infraleve e shandy continuou viajando, indo bem além de seu tempo e espaço. Hoje, ele está presente no espírito de novas sociedades secretas, como a ar de Dylan. Está presente em diversos museus, em diversas partes do mundo. Mas está presente também nas ruas, em manifestações anarquistas e no espírito de quem acredita no brilho da insolência nas artes. 


\subsection{Entre autores e narradores}

Walter Benjamin, que em Historia abreviada é o criador de um dos mais importantes inventos shandys, a máquina risonha de pesar livros, começa seu ensaio $O$ narrador (1936) afirmando que "por mais familiar que seja seu nome, o narrador não está de fato presente entre nós, em sua atualidade viva. Ele é algo distante, e que se distancia ainda mais" (BENJAMIN, 1987, p 197). Assim, quando ao se ler Borges o leitor se depara com um narrador chamado Borges, sente-se, muitas vezes, a tentação de pensar até qual ponto este narrador dá voz ao próprio autor. Por outro lado, essa mesma possibilidade alerta sobre a necessidade de diferencia-los e de situar o narrador em um plano distinto tanto do autor quanto do leitor.

Com os narradores vilamatianos ocorre o mesmo. Grande parte deles são escritores que escrevem desde Barcelona e que não revelam seus nomes. É o caso dos narradores de Historia abreviada de la literatura portátil, Bartleby y compañía e Aire de Dylan, a linha portátil da produção literária do autor, segundo suas próprias palavras.

Das leituras destes três livros pode-se depreender muitos aspectos da carreira de Vila-Matas como escritor, principalmente neste último, já que se trata também de um diálogo entre o escritor maduro que ele se tornou e o ainda iniciante de Historia abreviada. E essa análise dos processos vivenciados pelo autor se dá não apenas pelo trabalho com as semelhanças entre ele e seus narradores, mas também pelas diferenças. $\mathrm{Na}$ da leitura de Bartleby e compañía, por exemplo, encontra-se aspectos que podem revelar as razões pelas quais Vila-Matas seguiu o caminho totalmente oposto ao do narrador que renunciou a escritura.

No entanto, se como propõe Benjamin, o narrador não está presente em nossa realidade viva, autores como Vila-Matas, Borges e tantos outros que, a partir de diferentes formas evocam a si próprios por intermédio de seus narradores, confirmam que o autor está bem vivo, retornando da morte anunciada por Barthes quando este afirma: "A escrita é esse neutro, esse compósito, esse oblíquo para onde foge o nosso sujeito, o preto-ebranco aonde vem perder-se toda a identidade, a começar precisamente pela do corpo que escreve" ( BARTHES, 1987, p.49).

No caso de Vila-Matas a escrita, ao invés de provocar a fuga do sujeito, é o espaço em que este tenta descobrir-se, alcançando ou não sucesso em sua busca. Assim, ao 
escrever o autor não abre mão da identidade, mas lança reflexões sobre ela, tanto à sua própria quanto ao que ela pode significar em uma obra literária.

Deste modo, suas narrativas também questionam quem sou eu? Que é a Literatura? E estas perguntas são estendidas ao leitor, que também passa a ter a responsabilidade de refletir sobre esta literatura. Em Crítica e verdade, quando comenta a metalinguagem aplicada à literatura, Roland Barthes afirma:

[...] como essa interrogação é levada adiante, não do exterior, mas na própria literatura, ou mais exatamente na sua margem extrema, naquela zona assintótica onde a literatura finge destruir-se como linguagem-objeto sem se destruir como metalinguagem, e onde a procura de uma linguagem se define em última instância como uma nova linguagem-objeto, daí decorre que nossa literatura é há vinte anos um jogo perigoso com sua própria morte, isto é um modo de vivê-la: ela é como aquela heroína raciniana que morre de se conhecer mas vive de se procurar. Ora, isso define um estatuto propriamente trágico: nossa sociedade, fechada por enquanto numa espécie de impasse histórico, só permite à sua literatura a pergunta edipiana por excelência: quem sou eu? Ela lhe proíbe, pelo mesmo movimento, a pergunta dialética: que fazer? A verdade de nossa literatura não é da ordem do fazer, já não é mais da ordem da natureza: ela é uma máscara que se aponta com o dedo (BARTHES, 2003, p. 28).

Por um lado, os romances vilamatianos se aproximam das teorias de Barthes, como quando o crítico francês comenta sobre essa literatura que garante sua existência pelo simples fato de questionar-se, conectando-se assim, com muitas obras de arte contemporâneas que emanam da própria procura por uma face que sirva de discurso.

Por outro lado, tais romances se distanciam de tal teoria, visto que Vila-Matas não se limita a confins metaliterários a ponto de se sustentar em outras obras e autores sem trazer inovações. Além disso, na maioria das vezes em que o espanhol evoca outros autores e obras, o faz para chegar a uma conclusão sobre si e sobre sua própria produção. 


\subsection{Vila-Matas, Duchamp e os sentidos por trás do sem sentido}

Quantos textos críticos, quantas aulas de literatura e de artes, quantas conversas entre amigos já foram destinadas à busca por desvendar o grande sentido de uma obra de arte? Esta sempre será uma postura possível do público frente a produções artísticas, e não é que estas sejam livres de significado, a questão é que a arte é mais do que produtora de sentidos. O objetivo aqui é discutir sobre o espaço da sensibilidade no mundo das artes e refletir sobre o posicionamento de Vila-Matas e da crítica literária ante tal tema.

Em diversos momentos de sua obra, principalmente as do início de sua carreira, Vila-Matas empreende uma investigação sobre aquilo que não tem sentido na arte e na vida. Mais do que propor indagações sobre o sem sentido, o autor defende que a arte, bem como a vida, pode ser mais plena sem a obrigatoriedade de que tudo faça sentido. No seu artigo El buzón de los fantasmas ele comenta que se nem na realidade podemos encontrar muito sentido, na literatura não poderia ser diferente:

É certo, me digo, não há quem entenda a realidade. No entanto, vivo em um país, Espanha, onde todo o mundo a entende perfeitamente; a realidades sempre causou furor, na literatura o realismo impera, passeia vulgarmente no alto da pirâmide. Mas eu sempre pensei que não há quem entenda a realidade e que por isso escrevo. A realidade, como a vida - como este fim de semana tão longo - não tem sentido, mas em compensação o tem a literatura, e suspeito agora que até este artigo — que se converteu em relato— acabará por ter sentindo, adquirirá - como se o visse - uma íntima coerência. Escrever é pactuar com o sem sentido do mundo. ${ }^{47}$

Assim, não apenas a escritura, mas toda produção artística, não deveriam se perder na obrigatoriedade de fazer sentido. Esta despretensão de explicar o mundo e de auto explicar-se é um dos aspectos dos artistas vanguardistas que Vila-Matas admira e que leva a diversas de suas obras, muitas vezes ficcionalizando estes artistas, como tantas vezes o fez com Marcel Duchamp.

\footnotetext{
47 "Es cierto, me digo, la realidad no hay quien la entienda. Sin embargo vivo en un país, España, donde todo el mundo la entiende perfectamente; la realidad siempre ha hecho furor, en literatura el realismo impera, se pasea chulescamente en lo alto de la pirámide. Pero yo siempre he pensado que la realidad no hay quien la entienda y que por eso escribo. La realidad, como la vida - como este fin de semana tan largo-, no tiene sentido, pero en cambio sí lo tiene la literatura, y sospecho ahora que hasta este artículo - que se me ha vuelto relato - acabará por tener sentido, adquirirá — como si lo viera - una íntima coherencia. Escribir es pactar con el sinsentido del mundo" (VILA-MATAS, 2001).
} 
Em 1917, Duchamp expunha pela primeira vez seu ready-made Fonte (1917), naquele momento, mais que provocar críticos e público que claramente, em sua maioria, não aceitaram aquela proposta, além de levantar uma série de questionamentos sobre o que seria a arte e qual seria seu espaço e sua função, o artista francês rompia com diversas visões limitadoras sobre arte e, segundo TODOROV "tornava vã toda procura por sentido e verdade" (2009, p. 69).

Porém, o fato desta procura por sentido ser vã, não significa que os ready-mades de Duchamp, bem como as obras dos mais diversos artistas, com suas mais diversas técnicas, não se comuniquem com o público por meio de seus materiais, atingindo seus sentimentos e provocando reflexões.

É claro que estas obras que rompem com velhos mecanismos e trazem novas propostas para o universo das artes também exigem uma postura diferente por parte do crítico ou estudioso que se propõe a analisá-las. Aquele que analisar este estudo averiguando elementos e coletando dados a fim de encontrar um sentido, estará reduzindo potencialmente o valor de qualquer obra de arte, produzida em qualquer momento, especialmente estas cujo um dos principais objetivos é justamente eliminar a ideia de que uma obra de arte precisa ter um sentido.

Mais de 100 anos depois da exposição do primeiro ready-made de Duchamp, encontramos diversas análises para cada uma de suas obras. É possível encontrar interpretações completamente distintas para uma única obra, e não se pode dizer se há alguma correta ou equivocada, apenas podemos dizer que algumas são mais limitadas, já que se utilizam de métodos quase científicos para estudar o que é artístico e humano, consequentemente, não exato. Por outro lado, há críticos que antes de buscar sentidos, deixam que uma obra lhe desperte os sentidos e assim, antes de buscarem um resultado, vivem as experiências que tal obra convida a viver.

Vila-Matas desaprova os críticos que reduzem o valor da produção duchampiana devido o desinteresse do francês em dar explicações complexas e claras sobre seus trabalhos. No artigo Un Duchamp relajado ele comenta:

O que pode ocorrer com tanto desvario intelectual (de intelectual francês em sua maioria) é que muitos não podiam suportar que Duchamp houvesse desejado, ao final de sua vida, das para suas "coisas" (assim chamava a suas obras) explicações relaxadas, simples, concisas, sem segundas intenções complexas, ou intenções secretas. Muitos intelectuais adoradores deste artista não quiseram aceitar esse lado trivial de seu mito, porque isso equivalia a questionar as interpretações que este ou o outro haviam elaborado em torno à sua obra. Ou seja, todo mundo queria se apropriar dela. No entanto Duchamp 
nunca pertenceu a ninguém, e por sorte ninguém nunca possuiu sua chave, nem ninguém desvendará seu mistério. Tanto mais porque não há mistério nem chave..$^{48}$

Essa impossibilidade que as obras de Duchamp apresentam de gerar um sentido único e definitivo, ao mesmo momento em que é visto como uma grande qualidade artística para pessoas como Vila-Matas, também é motivo de duras críticas para outros. É o caso do poeta e crítico brasileiro Affonso Romano de Sant' Anna que já publicou dois livros em que critica ferrenhamente a Duchamp e a outros artistas que se dedicam à arte conceitual.

Em um aspecto Vila-Matas e Sant'Anna concordam: Duchamp tinha uma vida divertida. Porém, na visão do brasileiro, a maior diversão de Duchamp era blefar com seu público, criar objetos aleatórios e vazios de significado e esperar que o público lhes atribuísse muitos e importantes significados.

Em O enigma do vazio: impasses da arte e da crítica (2008), o que Sant'Anna faz é justamente revisar a análise que outros críticos realizaram da obra de Duchamp e sua conclusão é que as mentes de muitos dos que escreveram sobre a produção duchampiana eram muito mais engenhosas que a do francês, já que conseguiam extrair textos e análises brilhantes de obras que não seriam, segundo Sant'Anna, mais do que blefes, objetos totalmente vazios de significado esperando que alguém tirasse algo relevante de onde na verdade não havia nada. No entanto, do mesmo modo que as obras de Duchamp, bem como a arte vanguardista de maneira geral, sofreram e ainda sofrem severas críticas, elas também são admiradas e comentadas por muitos, como o próprio Vila-Matas.

Octavio Paz também foi um admirador de Duchamp, tanto que escreveu Apariencia desnuda, livro onde realiza sua análise de diversas obras do artista francês, em especial o Grande vidro. Como já mencionado, esta análise foi uma das que

\footnotetext{
48 "Lo que pudo ocurrir con tanto desvarío intelectual (de intelectual francés en su mayoría) es que muchos no podían soportar que Duchamp hubiera querido, al final de su vida, dar de sus "cosas" (así llamaba a sus obras) explicaciones relajadas, sencillas, concisas, sin segundas intenciones complejas, o intenciones secretas. Muchos intelectuales adoradores de este artista no quisieron aceptar ese lado trivial de su mito, porque eso equivalía a poner en entredicho las interpretaciones que éste o el otro habían elaborado en torno a su obra. Es decir, todo el mundo quería apropiárselo. Sin embargo, Duchamp, nunca ha pertenecido a nadie, y por suerte nadie ha poseído nunca su clave, ni nadie desvelará nunca su misterio. Tanto más cuanto no hay misterio ni hay clave" (VILA-MATAS, 2013).
} 
Sant'Anna comentou, afirmando que se trata de um texto belíssimo, de uma interpretação incrível, que estaria bem além do que Duchamp e sua produção mereciam.

Do mesmo modo que Vila-Matas, Duchamp também possuía um vínculo com a América Latina, tanto que o argentino Raúl Antelo publica em 2010 o livro Maria com Marcel: Duchamp nos trópicos, cujo intuito é analisar como a diversificada cultura latinoamericana "incide na elaboração da teoria modernista da arte e da sensibilidade no Ocidente" (ANTELO, 2010 p.09). Duchamp, suas obras e as suas passagens por países da América Latina estão no centro dessa discussão que também se relaciona com o espaço que as teorias que enfatizam a sensibilidade no mundo das artes têm ocupado atualmente.

Hans Ulrich Gumbrecht é outro teórico que contribuiu com esta discussão. Em Atmosfera, ambiência, Stimmung: sobre um potencial oculto da literatura, ele defende que neste momento no qual se nota "uma necessidade aumentada - e um maior desejo de encontros com a presença" (GUMBRECHT, 2014, p. 17), o estudo literário precisa dedicar atenção às atmosferas e ambientes que se apresentam em uma obra de arte.

Neste livro, Gumbrecht comenta textos literários, pinturas e músicas, entre estas Me and Bobby Mcgee, de Janis Joplin. No trecho intitulado "A liberdade na voz de Janis Joplin”, o autor relata como a voz da cantora americana fez e sempre fará parte da vida de pessoas de toda uma geração, da capacidade de obras de arte como esta canção de nos transportar para outros tempos, outros espaços: “A música e as vozes do passado eletrificam nossa pele e nos chamam para longe do presente. Nada é tão forte - nada incorpora esse mundo de maneira tão completa" (Idem, p. 121).

Gumbrecht ainda faz uma análise de trechos da letra da música, comentando como a voz de Joplin vai se alterando, transmitindo ora a suavidade que encontrava ao tocar as mãos de Bobby McGee, ora a dor pela felicidade perdida. Logo a voz, assim como as palavras e os sons dos instrumentos se fundem e toda tentativa de entendimento passa a ser desafiada. Mas a letra da canção e os sentidos que abriga são apenas auxiliares, tanto que mesmo o ouvinte que não fala inglês é capaz de se conectar com Stimmung existencial transmitido pela voz de Janis Joplin.

Este potencial de tocar e provocar os sentimentos humanos é um atributo não só da música, mas da literatura e das artes visuais. Uma das queixas de Vila-Matas é que, para muitos, acaba triunfando o potencial da arte de gerar compressões sobre o de gerar emoções.

Ao se considerar o número de pessoas que já se sentiram extremamente tocadas por músicas as quais não conheciam uma palavra, pode-se deduzir que o fato de não se 
chegar a conclusões quanto ao sentido exato de uma obra não significa que esta seja irrelevante ou incapaz de estabelecer uma relação com o público.

Em um de seus artigos publicados no periódico El País, Vila-Matas comenta sobre uma lista de filmes famosos por não serem compreensíveis. Neste artigo, que leva o mesmo nome de um desses filmes que retratam o incompreensível, El sueño eterno, de Howard Hawks, o autor se questiona: “de verdade não entender é uma condenação? Em vez disso, eu diria o contrário, não entender é a porta que se abre"49.

Para Vila-Matas, um dos grandes trunfos da arte é a imaginação, tanto a do artista quanto a do receptor que preenche os vazios presentes na obra. Uma produção artística que não explica tudo abre portas para a imaginação e para a experiência do leitor. Esta despreocupação em dar sentido a suas obras é uma das características de Marcel Duchamp admirada pelo escritor catalão que admite em diversos momentos o que se evidencia na maioria de suas obras, que as ideias de Duchamp sobre arte são algumas de suas principais fontes de inspiração.

Não é em vão que muitas vezes Vila-Matas transformou o artista francês em um de seus personagens, bem como outros diversos artistas. Em Historia abreviada (1985), o autor cria uma atmosfera a partir da atmosfera de outras diversas obras. A música de Edgar Varèse (1883-1965), por exemplo, se conecta intimamente com o clima espectral que ronda os membros da conspiração secreta e parece ecoar em Praga, Viena e demais cidades por onde passaram os artistas das vanguardas da década de 20 que formaram essa sociedade.

A própria escolha destas cidades já traz indiretamente ao seu texto questões históricas e políticas, da mesma forma que o modo de vestir dos personagens, as obras citadas como as fotografias de Man Ray, as pinturas de Paul Klee, Picabia, Geogia O'Keef, os escritos de Walter Benjamin, Sterne, Jacques Rigaut, os ready-mades de Duchamp, entre as mais variadas obras de diversos artistas vanguardistas que carregam em si a essência do que foi o shandysmo, o espírito das vanguardas artísticas e consequentemente a situação da Europa durante o entreguerras.

Assim, ao reunir diversos climas e atmosferas, Vila-Matas constrói sua narrativa híbrida que se conecta com as mais diversas formas de manifestações artísticas, rompendo com fronteiras genéricas e territoriais. $\mathrm{O}$ autor chega a esse resultado também porque se

49 “¿de verdad no entender es una condena? Más bien diría lo contrario, no entender es la puerta que se abre". 
reteve nas atmosferas e ambientes apresentados em obras rechaçadas por muitos por serem consideradas apenas como objetos ou textos sem sentido.

Em Literatura em perigo, justamente após comentar sobre o mictório de Duchamp, Todorov afirma: “A ausência de finalidade externa, é de algum modo, compensado pela densidade das finalidades internas, ou seja, pelas relações entre as partes e os elementos da obra. Graças à arte, o ser humano pode atingir o absoluto" (2009, p.52). A questão é que mesmo quando uma obra de arte aparentemente não apresenta sentido "ela nos proporciona sensações insubstituíveis que fazem o mundo mais pleno de sentido e mais belo" (TODOROV, 2009, p. 23).

Assim, propõe-se uma nova maneira de se analisar a literatura, cuja preocupação central não seja mais a busca por seu sentido, mas a compreensão do texto a partir do que ele provoca no leitor. Ainda que determinadas obras não apresentem sentidos claros, elas despertam os sentidos e atribuem sentido à vida humana. 


\subsection{Mais mistério, por favor}

De los diversos instrumentos del hombre, el más asombroso es, sin duda, el libro. Los demás son extensiones de su cuerpo. El microscopio, el telescopio, son extensiones de su vista; el teléfono es extensión de la voz; luego tenemos el arado y la espada, extensiones de su brazo. Pero el libro es otra cosa: el libro es una extensión de la memoria y de la imaginación. ${ }^{50}$

Jorge Luis Borges

Das criações humanas a arte foi a que mais se permitiu ser misteriosa. Milhares de grandes segredos se ocultam por trás de obras de todos os tempos, fascinando o público e lhe envolvendo em seus mistérios. E Vila-Matas admite ser fascinado por este fascínio provocador. Provocador de incógnitas, de reflexões, de ideias e emoções.

Não há nada de errado em tentar desvendar os mistérios escondidos por trás de uma produção artística. É essa tentativa que converte o receptor em coautor da obra, já que é sua imaginação aliada à sua experiência que vai preencher certos vazios apresentados na obra. No entanto, esperar de uma composição que ela contenha todas as respostas necessárias para alcançar um sentido, no qual se chega principalmente por meio da razão, é ignorar o potencial da arte de tocar os sentimentos humanos e sua capacidade de provocar emoções no receptor, mesmo quando este não alcança seu significado.

De forma bastante imaginativa, Vila-Matas preencheu vazios de diversas obras quando travou diálogos com elas e seus autores. Preencheu com ficção a história e os manuais de arte, enquanto deles tirava o principal alimento de sua imaginação. Mais que preencher lacunas, apresentou outras tantas, agora a serem preenchidas por seus leitores. E sendo um grande aficionado pelo mistério, brindou seus leitores com muitos.

Como o próprio autor já revelou diversas vezes, seus textos, sejam artigos ou livros, começam sendo um mistério para ele mesmo. Como quem viaja em um deserto vazio, o autor segue caminhando sem saber o que encontrará. O importante é ter ideias

\footnotetext{
50 "Dos diversos instrumentos do homem, o mais assombroso é, sem dúvida, o livro. Os demais são extensões de seu corpo. O microscópio, o telescópio, são extensões de sua vista; o telefone é extensão da voz; logo temos o arado e a espada, extensões de seu braço. Mas o livro é outra coisa: o livro é uma extensão da memória e da imaginação."
} 
que sirvam de motivação e o ponha em movimento, a partir daí o caminho reserva novas surpresas. Quando se percebe, do deserto já se fez uma floresta de ideias.

Esta floresta se torna ainda mais densa quando passa a ser integrada também pela imaginação, experiência e ideias do público, que além de dialogar com as ideias que o autor transmitiu conscientemente, dialoga com as ideias que traspassam a intenção do autor. Em $O$ ato criador, Duchamp também comenta sobre o papel do público na execução de uma obra:

\begin{abstract}
No ato criador, o artista passa da intenção à realização, através de uma cadeia de reações totalmente subjetivas. Sua luta pela realização é uma série de esforços, sofrimentos, satisfações, recusas, decisões que também não podem e não devem ser totalmente conscientes, pelo menos no plano estético. $\mathrm{O}$ resultado deste conflito é uma diferença entre a intenção e a sua realização [...] por conseguinte na cadeia de reações que acompanham o ato falta um elo. [...] Devemos lembrar que este "coeficiente artístico" é uma expressão pessoal da arte à l'état brut, ainda num estado bruto que precisa ser "refinado" pelo público como o açúcar puro extraído do melado [...] $\mathrm{O}$ ato criador toma outro aspecto quando o espectador experimenta o fenômeno da transmutação; pela transformação da matéria inerte numa obra de arte [...] Resumindo, o ato criador não é executado pelo artista sozinho; o público estabelece o contato entre a obra de arte e o mundo exterior, decifrando e interpretando suas qualidades intrínsecas e, desta forma, acrescenta sua contribuição ao ato criador. Isto torna-se ainda mais óbvio quando a posteridade dá o seu veredicto final e, às vezes, reabilita artistas esquecidos (DUCHAMP, 1986, p. 73-74).
\end{abstract}

Em romances, ensaios, entrevistas, fica evidente o interesse de Vila-Matas por obras que convidam o público a compô-las. Em Kassel no invita a la lógica (2014), o narrador (mais um quase Vila-Matas), conta sua experiência como escritor convidado a participar da Documenta de Kassel, sendo ele mesmo centro de contemplação para o público, que poderá observá-lo enquanto escreve. Conta ele que, estando ali, foi afetado de diversas maneiras, por diferentes obras.

Conta, por exemplo, da visita que fez a uma instalação, um lugar um tanto estranho, do qual não sabia o que esperar. Enquanto buscava um significado para o que acontecia (ou deixava de acontecer) ali, algo ou alguém lhe tocou as costas. Não soube dizer o que havia acontecido, até imaginar que se tratava da própria obra o convidando a compô-la. Assim, chega à conclusão que: "a arte faz, e então você que a componha, o toque já está feito, e agora depende de ti, vejamos como você a compõe"51.

\footnotetext{
51 “el arte hace, y ahí te la compongas [...] el roce ya está hecho, y ahora todo depende de tí, a ver cómo te la compones" (VILA-MATAS, 2010, P.61).
} 
No entanto, não se trata de estar tudo nas mãos do público. Se há tempos VilaMatas é um dos escritores que, dentro de suas narrativas, reivindicou sua vida como autor, não poderia deixar de ressaltar que para que exista um coautor, antes é preciso que exista um autor e uma obra. E a obra, como propõe Umberto Eco, pode conter milhares de interpretações possíveis, mas também contém os indícios necessários para anular interpretações incabíveis.

A partir de uma visão da semiótica, que se aproxima da Estética da Recepção, Umberto Eco (1932 - 2016), em Os limites da interpretação (1990) afirma que o texto literário é o conjunto de três intenções: a intenção do autor (intentio auctoris), a intenção do leitor (intentio lectoris) e ainda a intenção do texto (intentio operis). De acordo com Eco, esta última se trata de aspectos e mecanismos presentes dentro do próprio texto que pretere interpretações ilógicas e infundadas.

Não se trata da exigência de que autor, obra e público construam juntos uma única interpretação, mas que nenhuma das três intenções de que fala Eco seja menosprezada. Deste modo, o horizonte de expectativa e a experiência do leitor podem levá-lo a interpretações diversas, mas o texto sempre contém indícios para apontar se as diversas ideias de autor, obra e leitores passam pelas mesmas trilhas.

Historia abreviada de la literatura portátil e Aire de Dylan são exemplos de florestas de ideias. E o são não somente por serem resultado da reunião de múltiplas ideias de um homem, mas por serem ideias de um homem que adotou múltiplas faces e estabeleceu diálogos com as ideias de vários livros, de vários artistas, de várias personalidades adotadas por estes mesmos artistas, como Marcel Duchamp e Bob Dylan.

Originados no mistério, os romances são também celebração do enigmático no mundo das artes. Afinal, poucas coisas escondem mais segredos e causam mais curiosidade do que as práticas clandestinas de uma sociedade secreta, mesmo daquelas que, como as conspirações shandy e ar de Dylan, conspiram pelo fato mesmo de conspirar. Afinal, este ato de conspirar por conspirar, viajar por viajar, é também ansiar pelo mistério do que surgirá destas ações.

Shandys e Dylans também empreenderam viagens desconhecendo quais seriam os lugares aos quais chegariam. Enquanto shandys viajaram buscando inspiração para produzir, sinais que indicassem os caminhos que a conspiração deveria seguir e até mesmo os sentidos por trás de suas viagens, dylans empreendiam viagens buscando autores de frases, o brilho do autêntico e o silêncio. Em seus trajetos, seja movido por frases motores ou pela força do destino, ambas conspirações acabaram encontrando mais 
perguntas do que respostas, perguntas estas que se convertiam em motores para o início de novas jornadas.

Aliás, não fosse pela questão cronológica, shandys e dylans poderiam perfeitamente se unir em uma única conspiração cujo objetivo maior seria contemplar o mistério e as sensações causadas pelas pequenas coisas. Como a sociedade ar de Dylan chegou à conclusão de que pequenas coisas, apenas aparentemente insignificantes, como um simples desenho sobre o vapor em uma janela de vidro, poderia representar muitas coisas, alguns anos antes os shandys já haviam revelado:

Só as sensações mínimas e de coisas pequeníssimas são as que vivo intensamente. Pode ser pelo meu amor pelo fútil que isso acontece comigo. Pode ser pelo meu próprio escrúpulo no detalhe. Mas penso que talvez seja mais - não sei, essas coisas nunca as analiso - porque o mínimo, por não ter nenhuma importância social ou prática, tem, devido à mera ausência disso, uma independência absoluta de associações sujas com a realidade. O mínimo, e meu odradek o é, me sabe sempre irreal. O inútil é belo porque é menos real que o útil, que se continua e prolonga; ao passo que o maravilhoso fútil, o glorioso infinitesimal, fica onde está, não passa de ser o que é, vive livre e independente [...] O mistério nunca se transparece tanto como na contemplação das pequenas coisas que, como se movem, são perfeitamente translúcidas a ele, pois se detêm para deixa-lo passar. ${ }^{52}$

As máscaras de conspiradores portáteis e infraleves são apenas algumas das milhares que Vila-Matas utilizou para criar suas teorias. Aqui, o autor fala através de seus personagens e, mais uma vez, se posiciona contra a ideia de que a arte necessita estar associada à realidade ou conter um discurso social para que possua valor. Além disso, o autor também contempla e exalta a capacidade da arte de criar enigmas e mistérios em um momento em que muitos acreditam que o mais importante são as respostas, se esquecendo que elas não seriam possíveis se antes não existissem questionamentos e um dispositivo que os traga à tona.

\footnotetext{
52 "Sólo las sensaciones mínimas y de cosas pequeñísimas son las que vivo intensamente. Será por mi amor a lo fútil por lo que eso me sucede. Puede que sea por mi propio escrúpulo en el detalle. Pero más bien creo -no lo sé, estas cosas nunca las analizo- que es porque lo mínimo, por no tener en absoluto importancia ninguna social o práctica, tiene, debido a la mera ausencia de esto, una independencia absoluta de asociaciones sucias con la realidad. Lo mínimo -y mi odradek lo es- me sabe siempre a irreal. Lo inútil es bello porque es menos real que lo útil, que se continua y prolonga; al paso que lo maravilloso fútil, lo glorioso infinitesimal, se queda donde está, no pasa de ser lo que es, vive libre e independiente [...] El misterio nunca se transparenta tanto como en la contemplación de las pequeñas cosas que, como se mueven, son perfectamente traslúcidas a él, pues se detiene para dejarlo pasar" (VILA-MATAS, 1985, p. 59-60).
} 
Como o ready-made Fresh Window, um dos primeiros de Duchamp, a obra de arte também pode ser uma janela para o desconhecido. Incialmente vê-se somente uma escuridão enigmática, mas o espectador que se propor indagá-la, a poderá colorir com sua imaginação e suas ideias.

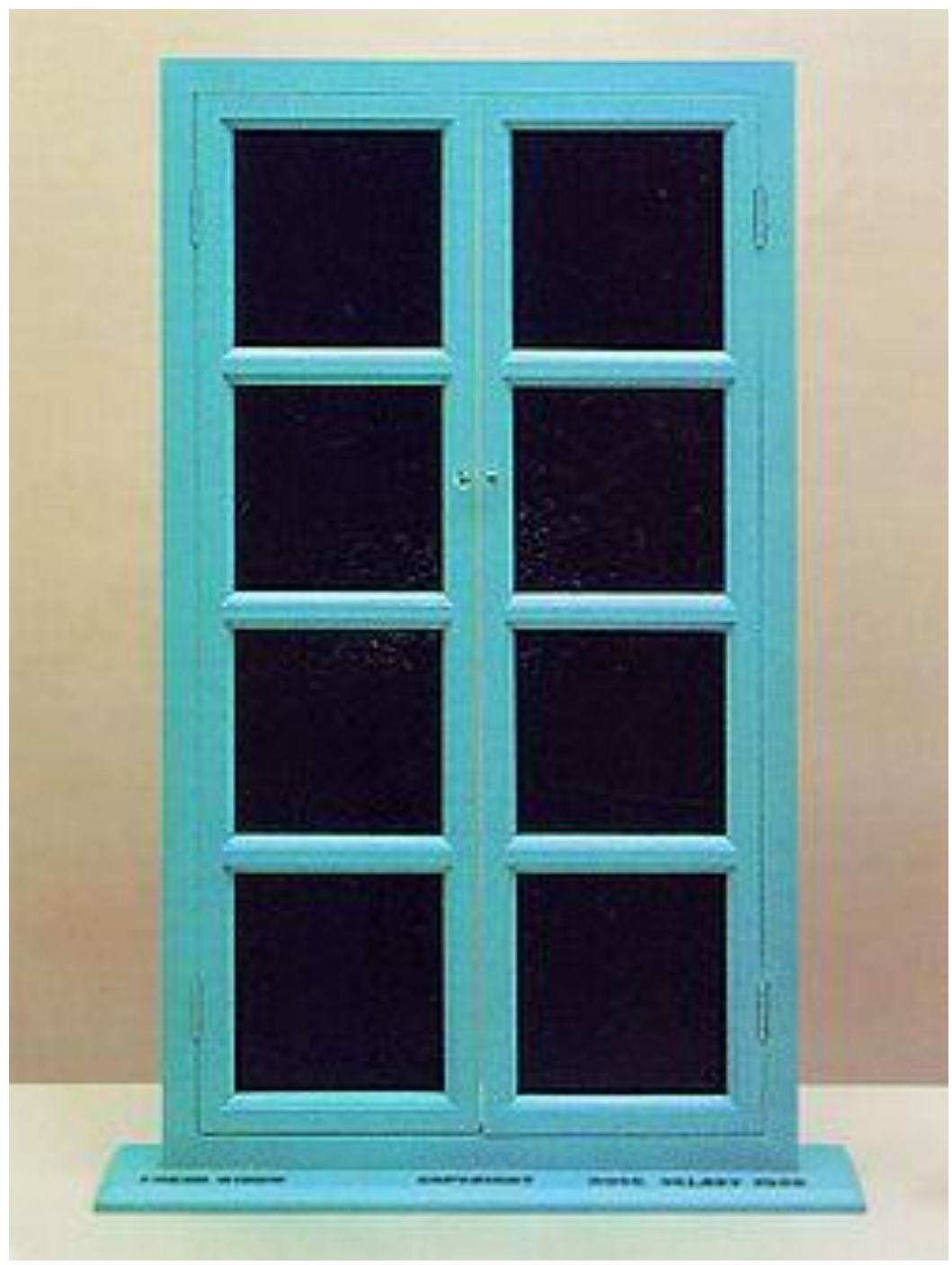

Figura 5 - DUCHAMP. Fresh Widow, 1920, réplica 1964.

Os mistérios que existem por trás de certas obras é o que elas possuem de mais significativo. Pensemos, por exemplo, na Mona Lisa de Da Vinci. Naqueles 77 x 53 centímetros, reside um dos grandes mistérios da humanidade. Entre outras incógnitas e possibilidades, o sorriso de Mona Lisa sempre gerou muitos questionamentos. Durante séculos, milhares de pessoas se perguntaram se ela está séria ou se está realmente sorrindo. Recentemente, um grupo de cientistas se reuniu para tentar desvendar esse 
mistério e depois de uma série de análises e cálculos acreditam ter encontrado a resposta. Segundo eles, tudo depende do ângulo pelo qual a obra é vista.

É normal uma obra de arte provocar tanta curiosidade a ponto de ser analisada por cientistas. No entanto, a percepção e as conclusões as quais um receptor chega através de sua própria experiência e a partir dos sentimentos que a obra lhe desperta é tão valida, ou até mais, que as conclusões alcançadas por qualquer cientista que tenha utilizado métodos matemáticos para interpretá-la.

A Vila-Matas, provavelmente pouco lhe importaria descobrir as reais intenções de Da Vinci, de Duchamp, ou de quem quer que fosse. Como autor que utiliza várias máscaras, inclusive a de si próprio, como também o fez Borges, Bob Dylan e outras grandes influências suas, não lhe interessa derrubar máscaras e descobrir um rosto real. O mais importante é caminhar pelo bosque da imaginação, pois é nele que reside a magia da literatura. 


\section{CONSIDERAÇÕES FINAIS}

Chego então, ao final dessa viagem, mas não ao destino final. Uma das grandes lições que aprendi com shandys e dylans é que mais importante que chegar a um destino, é a caminhada que nos leva até ele. É na caminhada que tudo acontece, nela se perdem países, teorias, tradições e se ganha amigos, conhecimento, histórias, ideias. É durante o percurso que obtemos os itens mais importantes para compor nossa bagagem.

Assim como todo viajante, volto com a bagagem mais cheia (contraditoriamente mais portátil e infraleve), do que quando embarquei, ainda que nela agora traga mais perguntas do que respostas, mais questionamentos do que tinha ao início e a certeza de que ainda havia muito a ser explorado nesse inesgotável mundo das narrativas de VilaMatas. Inesgotável não somente por si próprio, mas por nos levar a universos de outros artistas e autores, a explorar espelhos e labirintos até nos darmos conta de que a literatura é um mundo que não tem fim.

Deste modo, a inquietude pela consciência de que muitos tópicos não abordados aqui contribuiriam amplamente com as discussões planteadas também abre espaço para a satisfação de saber que a literatura está aí para isso. Para trazer questões à tona, apontar uma infinitude de caminhos possíveis e nos pôr em movimento.

Também aprendi que a literatura é um dos maiores e mais potentes canais de comunicação criados pelo homem. Ela reúne diversos horizontes e condensa a história da humanidade. Nela, autores e leitores separados por séculos de distância, têm a possiblidade de dialogarem e construírem novas perspectivas juntos, afinal se, por um lado, o passado originou o presente, por outro, este tem o poder de mantê-lo vivo, visto que a literatura prova que enquanto houverem leitores e escritores, nem o passado será imutável, pois de uma forma própria ele ainda habita entre nós, influenciando em nossa existência enquanto também o revisitamos.

No caso dos romances de Vila-Matas, isso também se faz possível porque autor, obras e personagens são duais em aparência. Tratam-se de obras que propõe rupturas e novidades, mas sem jamais esquecer as grandes influências do passado, fazendo da intertextualidade a ponte que permite que a historicidade da própria literatura transite do passado até o que dele surgiu e ainda surgirá.

Esta historicidade surge em um terreno autorreferencial, em que a literatura reflete sobre si própria, sem nenhuma pretensão de captar um reflexo de uma realidade exterior. 
No entanto, também não se trata da criação de um mundo fictício totalmente dissociado do real, já que a partir da utilização de nomes que o leitor reconhece como reais e da constante mescla entre realidade e ficção, Vila-Matas recorre a realidade, não para imitála, mas para criar um novo mundo a partir de elementos extraídos dela. Assim, suas obras atuam como colaboradoras da verdade e não como seu reflexo.

Do mesmo modo como a literatura está sempre se transformando, a teoria literária também precisa caminhar para compreender e discutir os novos vieses literários que surgem. A Estética da Recepção, ainda que seja um método parcial que se torna mais abrangente com o auxílio de outras teorias e disciplinas, possibilitou discussões mais complexas acerca destas obras que criam um mundo em si.

Nas narrativas vilamatianas, a construção destes mundos próprios se dá com a utilização de vozes alheias. Mais do que isso, a imagem do (ou dos) Vila-Matas que o próprio autor cria, se constitui por vozes e atributos alheios. É como ele afirma em Dietario voluble:

Escrevemos sempre depois de outros, e talvez por isso tantas vezes persegui com citações literárias distorcidas ou inventadas que ajudavam a criar sentidos diferentes - uma imagem minha feita com características alheias, e talvez por isso tantas vezes fragmentei o antigo texto da cultura, e disseminei suas características as tonando irreconhecíveis, do mesmo modo em que se disfarça uma mercadoria roubada. Assim fui abrindo caminho, assim fui avançando. Para andar por aí nada tranquiliza tanto como uma máscara. Me sentia um depravado quando me alegrava em segredo me disfarçar tanto, de construir meu estilo com caminhadas alheias. ${ }^{53}$

Assim, o autor utiliza vozes e máscaras de outros artistas na busca por conhecer melhor seu próprio rosto. Como ele mesmo já admitiu, além de buscar por si próprio, ele também trabalha na construção de sua automitografia. Para isso, conta também com o intercâmbio de ideias com outro artista que soube bem construir sua própria mitografia, Marcel Duchamp.

A figura do francês perpassa toda a produção vilamatiana, mas em Historia abreviada de la literatura portátil e Aire de Dylan, essa dimensão é ainda mais acentuada.

\footnotetext{
${ }^{53}$ Escribimos siempre después de otros, y quizás por eso tantas veces perseguí -con citas literarias distorsionadas o inventadas que ayudaban a crear sentidos diferentes- una imagen mía hecha con rasgos ajenos, y quizá por eso tantas veces fragmenté el antiguo texto de la cultura, y diseminé sus rasgos haciéndolos irreconocibles, del mismo modo en que se maquilla una mercadería robada. Así fui abriéndome camino, así fui avanzando. Para andar por ahí nada tranquiliza tanto como una máscara. Me sentía un depravado cuando me alegraba en secreto disfrazarme tanto, de construir mi estilo con andaduras ajenas (VILA-MATAS, 2008, P. 228).
} 
Nestes romances, a figura de Duchamp atua como figura de relevância, condensando o espírito do texto e as ideias que este tenciona transmitir.

Vila-Matas faz da figura de Duchamp sua companhia de diversas viagens. Junto a ela o autor constrói sua automitografia e suas ideias de arte, além de utilizá-la como elemento que chama seus leitores a também discutirem e refletirem sobre os pontos levantados em suas obras.

Obras estas que são leves (e nada lights) porque se permitem ao riso, riem dos outros, riem de si mesmas e apresentam vazios cheios de significados e possibilidades. São vazios que falam mais do que muitas obras graves, repletas de temas sérios. São obras que captam o espírito de momentos importantes da história da humanidade porque, ao invés de se concentrarem em cor local, centram-se na arte mesmo e na capacidade desta de captar a essência da humanidade.

Aqui, termino essa viagem que me levou e ainda levará por rumos desconhecidos. Depois dela, compreendi que viajar é a melhor experiência para ampliar nossa percepção de quanto o mundo é muito maior e mais complexo do que podemos imaginar, ainda mais se nos referimos ao mundo da literatura que, além de não ter fim, ainda é capaz de nos transportar a outros universos infinitos. 


\section{REFERÊNCIAS}

AGAMBEN, Giorgio. O que é o contemporâneo? E outros ensaios. Trad. Vinícios Niscastro Honesko. Chapecó: ARGOS, 2009.

ANTELO, Raúl. Crítica acéfala. Buenos Aires: Editorial Grumo, 2008.

. Maria com Marcel: Duchamp nos trópicos. Belo Horizonte: Editora UFMG, 2010.

ARISTÓTELES. A poética clássica. São Paulo: Editora Cultrix, 1997.

BAEZA, Felipe (org.). Enrique Vila-Matas: los espejos de la ficción. Puebla, México, 2012.

BARTHES, Roland. O rumor da língua. Trad. António Gonçalves. Lisboa: Edições 70, 1987.

. Crítica e verdade. Trad. Leyla Perrone-Moisés. São Paulo: perspectiva,

2003.

BENJAMIN, Walter. A obra de arte na era de sua reprodutibilidade técnica. In: Magia e técnica, arte e politica: ensaios sobre literatura e história da cultura. Obras escolhidas vol.1. Tradução de Sérgio Paulo Rouanet. São Paulo: Ed. Brasiliense, 1987.

O Narrador. In: Magia e técnica, arte e política: ensaios sobre literatura e história da cultura. Obras escolhidas vol.1. Tradução de Sérgio Paulo Rouanet. São Paulo: Ed. Brasiliense, 1987.

BORGES, Jorge Luis, Obras completas - 1923-1972. Buenos Aires: Emecé Editores. 1974.

. Kafka e seus precursores (1951), in: Outras inquisições (1952). Obras completas. vol. 2. São Paulo: Globo, 1999, p. 96-98.

. Nove ensaios dantescos e a memória de Shakespeare. Trad. Heloisa Jahn.

São Paulo: Companhia das Letras, 2011.

CABANNE, Pierre. Conversaciones con Marcel Duchamp. Trad. Jordi Marfá. Barcelona: Anagrama, 1967.

. Marcel Duchamp: engenheiro do tempo perdido. Trad. Paulo José Amaral.

São Paulo, Perspectiva, 2008. 
CALLE, Sophie. Histórias reais. Trad. Hortencia Santos Lencastre. Rio de Janeiro: Agir, 2009

CANDIDO, Antonio. Formação da literatura brasileira: momentos decisivos. $6^{\text {a }}$ edição. Belo Horizonte, Editora Itatiaia Ltda, 2000. Literatura e sociedade. $9^{\text {a }}$ edição. Rio de Janeiro: Ouro sobre Azul, 2006.

CALVINO, Italo. Seis propostas para o próximo milênio. Trad. Ivo Barroso. São Paulo: Companhia das Letras, 1993.

COMPAGNON, Antoine. O Demônio da Teoria: literatura e senso comum. Trad. Cleonice Paes Barreto Mourão. Belo Horizonte: Editora da UFMG, 1999.

COSTA LIMA, Luiz. Mímesis: desafio ao pensamento. Rio de Janeiro: Civilização Brasileira, 2000.

O controle do imaginário \& a afirmação do romance: Dom Quixote, As relações perigosas, Moll Flanders, Tristram Shandy. São Paulo: Companhia das Letras, 2009.

DUCHAMP, Marcel. O Ato Criador In: BATTCOCK, Gregory. A Nova Arte. Trad. Cecília Prada e Vera de Campos Toledo. São Paulo. Perspectiva, 1986.

. Notes. Paris: Flammarion, 1999.

ECO, Umberto. Os limites da interpretação. São Paulo: Editora Perspectiva, 1990.

GADAMER, Hans-Georg. Verdade e método. Tradução de Flávio Paulo Meurer (revisão da tradução de Enio Paulo Giachini). 7. ed. Petrópolis: Vozes, Bragança Paulista: EDUSF, 2005.

GENETTE, Gerard. Palimpsestes: La literatura en segundo grado. Trad. Celia Fernández Prieto. Taurus, 1982.

. Figuras III. Trad. Carlos Manzano. Barcelona: Editorial Lumen. 1989.

Paratextos Editoriais. Trad. Álvaro Faleiros. São Paulo: Ateliê Editorial, 2009

GUMBRECHT, Hans Ulrich. Atmosfera, ambiência, stimmung: sobre um potencial oculto da literatura. Rio de Janeiro, Contraponto/ PUC Rio, 2014. 
HEREDIA, Margarita (org.) Vila-Matas portátil. Un escritor ante la crítica, Candaya, 2007.

JAUSS, Hans Robert. A história da literatura como provocação à teoria literária. Tradução de Sérgio Tellaroli. São Paulo: Ática, 1994.

A Estética da Recepção: colocações gerais. In: JAUSS, Hans Robert. Et. Al. A literatura e o leitor: textos de estética da recepção. 2. ed. Coordenação e tradução Luiz Costa Lima. Rio de Janeiro: Paz e Terra, 2002.

- O prazer estético e as explicações fundamentais da poiesis, aisthesis e Katharsis. In: JAUSS, Hans Robert. Et. Al. A literatura e o leitor: textos de estética da recepção. 2. ed. Coordenação e tradução Luiz Costa Lima. Rio de Janeiro: Paz e Terra, 2002.

KAFKA, Franz. As preocupações de um pai de família. In: Um médico rural. Trad. Modesto Carone. 3. ed. São Paulo: Brasiliense, 1994.

KLEIN, Kelvin dos Santos Falcão. Vozes compartilhadas: a poética intertextual de Enrique Vila-Matas. Dissertação de mestrado. Universidade Federal do Rio Grande do Sul. Porto Alegre: UFRGS, 2009

LUKÁCS, György. Ensaios sobre literatura. Rio de Janeiro: Editora Civilização Brasileira S.A. 1965.

. Estética. La peculiaridad de lo estético. Vol. 2. Barcelona: Grijalbo, 1965. . "Introdução aos escritos estéticos de Marx e Engels". In: MARX, Karl \& ENGELS, Friedrich. Cultura, arte e literatura: textos escolhidos. São Paulo: Expressão Popular, 2010.

Narrar ou descrever? Uma discussão sobre naturalismo e formalismo. Marxismo e teoria da literatura. Trad. Carlos Nelson Coutinho. 2. ed. São Paulo: Expressão Popular, 2010.

MATHEU, Shaj. 2015. Welcome to literature's Duchamp momento. Disponível em: $<$ https://newrepublic.com/article/121603/avant-garde-literature-starting-resembleconceptual-art>. Acesso em 25 de mai. 2015.

MELVILLE, Herman. Bartleby, El escribiente. trad. de Jorge Luis Borges, Madrid: Ediciones Siruela, 1984.

OREJAS, Francisco G. La metaficción en la novela española contemporánea. Madrid: Arco Libros, 2003. 
PAZ, Octavio. Apariencia desnuda: La obra de Marcel Duchamp. México, D.F. Ediciones Era, 1973.

PERRONE-MOISÉS, Leyla. Flores da escrivaninha - ensaios. São Paulo: Companhia das Letras, 1990.

PESSOA, Fernando. Poesias. Fernando Pessoa. Lisboa: Ática, 1942 (15 a ed. 1995). p. 182.

PITOL, Sérgio. Vila-Matas, premiado. $2001 . \quad$ Em: $<$ http://www.letraslibres.com/mexico/vila-matas-premiado>. Acesso em 16 de ago. 2016.

POE, Edgar Allan. Poemas e Ensaios. Trad. Oscar Mendes e Milton Amado. São Paulo: Globo, 1999.

SANT'ANNA, Affonso Romano de. Desconstruir Duchamp: Arte na hora da revisão. São Paulo: Vieira \& Lent, 2003.

. O enigma do vazio: impasses da arte e da crítica. São Paulo: Rocco. 2008.

SHAKESPEARE, William. Romeu e Julieta; Macbeth; Hamlet, príncipe da Dinamarca; Otelo, o Mouro de Veneza. Trad. F Carlos de Almeida Cunha Medeiros e Oscar Mendes. São Paulo: Abril Cultural, 1981.

STERNE, Laurence. A vida e as opiniões de Tristram Shandy. Trad. José Paulo Paes. Rio de Janeira: Nova Fronteira, 1984.

STIERLE, Karlheinz. Que significa a recepção dos textos ficcionais. In: JAUSS, Hans Robert et al. A literatura e o leitor: textos de estética da recepção. Trad. Luiz Costa Lima. Rio de Janeiro: Paz e Terra, 1979.

TODOROV, Tzvetan. Literatura em perigo. Trad. Caio Meira. Rio de Janeiro: DIFEL, 2009.

VILA-MATAS, Enrique. Al sur de los párpados. Madrid: Fundamentos, 1980.

Historia abreviada de la literatura portátil. Barcelona: Anagrama, 1984.

Impostura. Barcelona: Anagrama, 1984.

Suicidios ejemplares. Barcelona: Anagrama, 1991.

La asesina ilustrada. Madrid: Lengua de Trapo, 1996. 
El viaje vertical. Barcelona: Anagrama, 1999.

El buzón de los fantasmas. 2001. Disponível em: <http://www.letraslibres.com/mexico/el-buzon-los-fantasmas>. Acesso em 14 de jun. 2016. El mal de Montano. Barcelona: Anagrama, 2002. París no se acaba nunca. Barcelona: Anagrama, 2003.

Aunque no entendamos nada. Santigo do Chile: JC Saez Editor, 2004. . Bartleby y compañía. Barcelona: Anagrama, 2004.

. Doctor Pasavento. Barcelona: Anagrama, 2005.

. Dietario voluble. Barcelona: Anagrama, 2008.

El viento ligero en Parma. Madrid: Editorial Sexto Piso, 2008.

Una vida absolutamente maravillosa. 2009. Disponível em: <http://elpais.com/diario/2009/04/18/babelia/1240012214_850215.html>. Acesso em: 22 de jan. 2015.

Un atisbo de la realidad. 2009. Disponível em: <http://elpais.com/diario/2009/03/22/catalunya/1237687641_850215.html>. Acesso em: 16 de ago. 2016.

Perder teorías. Barcelona: Seix Barral, 2010.

. En un lugar solitario. Narrativa 1973-1984. Barcelona: Debolsillo, 2011.

. Aire de Dylan. Barcelona: Seix Barral, 2012.

Levedad: Ida y vuelta. 2012. Disponível em: $<$ http://www.enriquevilamatas.com/textos/textcontinuacombate.html>. Acesso em $20 \mathrm{de}$ mai. 2015.

Un Duchamp relajado. 2013. Disponível em: <http://cultura.elpais.com/cultura/2013/03/18/actualidad/1363631713_066480.html. Acesso em 25 mai. 2016.

. Kassel no invita a la lógica. Barcelona: Seix Barral, 2014. 
El sueño eterno. 2015. Disponível em:

<http://elpais.com/elpais/2015/05/19/opinion/1432060147_455589.html>. Acesso em 16 de ago. 2016.

Hambre de realidad. 2015. Disponível em: <http://cultura.elpais.com/cultura/2015/06/22/actualidad/1434984033_881914.html>. Acesso em 16 de ago. 2016

Dominio de la parte inventada. 2016. Disponível em: <http://cultura.elpais.com/cultura/2016/01/04/actualidad/1451908390_100765.html>. Acesso em 16 de ago. 2016.

Escribir es dejar de escribir. Disponível em <https://www.barcelonareview.com/23/s_escribir.htm>. Acesso em 16 de ago. 2016 